\title{
Assessment of microbial DNA enrichment techniques from sino-nasal swab samples for metagenomics*
}

\author{
Brett Wagner Mackenzie', David W. Waite ${ }^{2,3}$, Kristi Biswas', \\ Richard G. Douglas' ${ }^{1}$ Michael W. Taylor ${ }^{3,4}$ \\ Rhinology Online, Vol 1: 160 - 193, 2018 \\ http://doi.org/10.4193/RHINOL/18.052
}

'School of Medicine, Department of Surgery, The University of Auckland, Auckland, New Zealand

${ }^{*}$ Received for publication:

Australian Centre for Ecogenomics, School of Chemistry and Molecular Biosciences, University of Queensland, Brisbane, Australia August 14, 2018

${ }^{3}$ School of Biological Sciences, The University of Auckland, Auckland, New Zealand

Accepted: October 17, 2018

${ }^{4}$ Maurice Wilkins Centre for Molecular Biodiscovery, The University of Auckland, Auckland, New Zealand

Published: October 24, 2018

\begin{abstract}
Background: The role of the sinus microbiota, including bacteria, fungi and viruses, in health and disease remains unclear despite the application of molecular microbiological techniques to describe the microbiome. This is due, in part, to the overwhelming proportion of contaminating host DNA compared with recovered microbial DNA.
\end{abstract}

Methods: In this study, three techniques were assessed for microbial DNA enrichment: 1. A series of centrifugation steps, 2. Enrichment of microbial DNA using the NEBNext ${ }^{\circledR}$ Microbiome DNA Enrichment kit, and 3. Whole-genome amplification following the previous enrichment strategies. A no-treatment control and a whole-genome amplified control were also included. Swab samples from three adult patients undergoing functional endoscopic sinus surgery for chronic rhinosinusitis (CRS) were collected intraoperatively for this study. Paired-end shotgun metagenome sequencing was conducted using Illumina HiSeq and bacterial $16 \mathrm{~S}$ rRNA gene amplicon sequencing using Illumina MiSeq to assess bacterial community composition.

Results: After quality filtering of metagenomic sequences, the centrifugation method returned the highest proportion of microbial reads $(1.1 \pm 1.7 \%)$ compared to the no-treatment control $(0.15 \pm 0.07 \%)$. However, this result was neither reproducible nor was centrifugation significantly different to the other methods. Despite low recovery of total microbial DNA from metagenomic sequencing, a Propionibacterium acnes genome ( $97 \%$ complete) was recovered, suggesting metagenomic sequencing techniques can still be successfully applied to investigate the microbial component of CRS.

Conclusions: Based on these results, we recommend omitting microbial DNA enrichment steps and sequencing fewer samples per metagenomic sequencing run to increase the depth of sequencing without altering in situ microbial community structure.

Key words: Human microbiome, chronic rhinosinusitis, bacterial genome, metagenomics, microbiota, Propionibacterium acnes

\section{Introduction}

Contemporary sequencing technologies, such as targeted amplicon sequencing and shotgun metagenomics approaches, have provided unprecedented insights into the structure and function of the human microbiome ${ }^{(1-3)}$. One aspect of human microbiome study that has particularly benefitted from the application of high-throughput sequencing techniques is that of chronic sinus disease. In chronic rhinosinusitis (CRS) long-term inflammation of the sino-nasal mucosal lining severely impacts patient quality of life and places a substantial burden on health care systems ${ }^{(4-6)}$. Molecular technologies have transformed the way we view the role of the microbiota in CRS pathogenesis ${ }^{(7-10)}$. It now appears that these communities are imbalanced (dysbiotic), and characterized by a significant increase in bacterial load accompanied by a decrease in overall bacterial diversity ${ }^{(9,11,12)}$.

Shotgun metagenomic sequencing can provide comprehensive, strain-level identification and functional information about viral, fungal, bacterial and archaeal diversity within a sample. Metagenomic sequencing thus offers great potential to deepen our 
understanding of CRS, yet its application to sino-nasal samples is not without challenges. The size of the human genome $(\sim 3$ billion bp) compared to that of a typical bacterium ( $\sim$ million bp for Escherichia coli) means that the presence of relatively few human cells can lead to overwhelming proportions of contaminating human DNA in a sample ${ }^{(13,14)}$. In one study of the human skin microbiome, nares samples had the highest proportion of reads, on average, that mapped to the human genome (98.2\%), when compared with 17 other skin sites ${ }^{(15)}$. Metagenomic studies of samples originating from the middle meatus, which acts as a reservoir for mucous drainage within the human sinuses, have not yet been conducted, and we therefore carried out a pilot study (unpublished data) to assess levels of recovered microbial versus human DNA. We found that less than $1 \%$ of quality-filtered sequencing reads were of microbial (viral, bacterial, archaeal, or fungal) origin. Based on this pilot study, we designed a methods study to test a variety of host DNA depletion and microbial DNA enrichment strategies.

Enrichment techniques can be applied to capture genomes of interest or remove contaminating DNA ${ }^{(16,17)}$. Probe-based methods that target a single organism have been adopted, but are not suitable for studying entire microbial communities ${ }^{(18)}$. Other methods such as differential cell lysis, filtration and centrifugation separate host and microbial cells based on physical properties, but may have varying results between samples depending on community composition and sample consistency ${ }^{(19-22)}$. A range of commercially produced kits are available for enriching microbial DNA from human-derived samples including MolYsis ${ }^{\circledR}$, Pureprover ${ }^{\oplus}$, LOOXSTER ${ }^{\oplus}$, Molyzm Ultra-Deep Microbiome Prep, and the NEBNext ${ }^{\oplus}$ Microbiome DNA Enrichment Kit, but all are associated with increased processing costs when compared with lysis, filtration and centrifugation methods. The efficacy of enrichment associated with these methods is variable and likely sample-type specific ${ }^{(23-28)}$.

Whole genome amplification refers to a process in which segments of entire genomes originating from any type of DNA, microbial or human, are amplified (unlike traditional PCR, in which primers target specific regions of DNA within genomes). Whole genome amplification (WGA) by multiple displacement amplification (MDA) involves binding of random hexamers to denatured DNA for the initial amplification followed by strand displacement with Phi29 polymerase. WGA MDA is very useful for low biomass samples; however, due to its non-targeted nature contaminating host DNA must be significantly reduced prior to WGA ${ }^{(20)}$.

A number of limitations are associated with each of the aforementioned enrichment strategies, such as enzymatic treatments applied to preferentially lyse human cells may also lyse bacterial cells ${ }^{(23-25,29)}$. Very few methods studies incorporating enrichment techniques and metagenomics sequencing from human mixed microbial communities are available and the majority of method enrichment comparisons focus on the detection of specific pathogens ${ }^{(17,20,30,31)}$. Additionally, many studies do not include non-spiked samples from patients which would validate the efficacy of these techniques on microbial communities in the clinical setting ${ }^{(24,25)}$. To date, no studies exist comparing enrichment techniques for metagenomic sequencing from sino-nasal samples. Based on known limitations and bias of a variety of enrichment techniques, we chose two different techniques for removing human DNA: a series of centrifugation steps prior to nucleic acids extraction and the NEBNext ${ }^{\oplus}$ Microbiome DNA Enrichment Kit, each in conjunction with whole genome amplification, in an attempt to enrich the total amount of microbial DNA before metagenomic sequencing. Additionally, we amplified the bacterial $16 \mathrm{~S}$ rRNA gene to investigate the effects of the chosen methods on the recovered bacterial community profiles and our ability to describe them accurately.

\section{Materials and Methods}

Three male, adult patients undergoing functional endoscopic sinus surgery for idiopathic CRS by a single surgeon (RD) were recruited from Auckland City Hospital, Auckland, New Zealand. Exclusion criteria included age $<18$ years, current smoker, symptoms of asthma, aspirin sensitivity, and antibiotic and prednisone usage within the four weeks prior to surgery (Additional file 1). Written consent from the patients and ethical approval (NTX/08/12/126) from the New Zealand Health and Disability Ethics Committee was obtained for this study. Sterile rayontipped swabs (Copan Diagnostics, Inc., Murrieta, CA, USA) were used to collect a total of 12 mucosal samples from the middle meatus of each patient ( 6 left, 6 right) at the time of induction of anaesthesia. Swabs were immediately placed in $1 \mathrm{~mL}$ RNAlater ${ }^{\circledR}$ solution and stored the same day at $-20^{\circ} \mathrm{C}$ until DNA extraction. A diagram outlining this study is found in Figure 1.

\section{Microbial DNA enrichment methods \\ No-treatment Control ( $N$ )}

Samples were thawed on ice, and DNA was extracted from pairs of swabs from the same patient (1 left, 1 right) using the Qiagen ${ }^{\circledR}$ AllPrep DNA/RNA Mini Kit (Bio-Strategy LTD., Auckland, New Zealand) as previously described ${ }^{(9)}$. Elution Buffer EB (55 $\mu \mathrm{L}$ ) was added to the spin column filter and incubated for $5 \mathrm{~min}$ before DNA was eluted by centrifuging for 1 min at 11,200 $x$ g. The eluate was centrifuged through the spin column filter a second time to increase DNA concentration. Triplicate negative extractions of sterile water were performed to test the DNA extraction kit for contamination.

Yield ( $\mathrm{ng} / \mu \mathrm{L})$ and purity (260/280 $\mathrm{nm}$ absorbance ratio) of extracted DNA were determined spectrophotometrically using the NanoDrop ${ }^{\circledR}$ ND-1000 (NanoDrop Technologies Inc., Wilmington, USA). DNA yield was also determined fluorometrically using the High Sensitivity (HS) kit on the Qubit ${ }^{\oplus}$ Fluorometer 1.0 (Invi- 


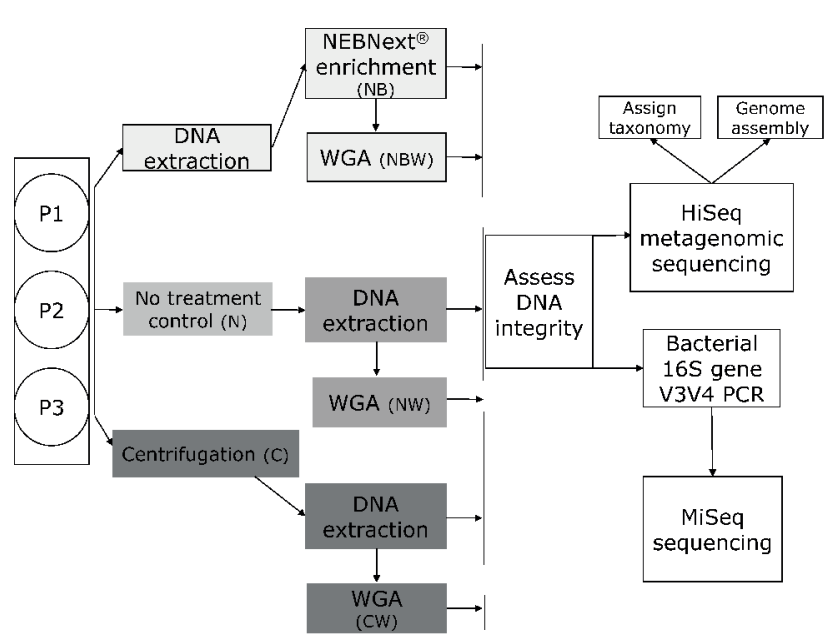

Figure 1. Schematic diagram showing the experimental design applied in this study. P1, P2, P3 refer to the individual CRS patients from whom samples were obtained.

trogen Co., Carlsbad, CA, USA). Integrity of genomic DNA was determined by visualizing $3 \mu \mathrm{L}$ of extracted DNA on a $0.8 \%$ agarose gel (w/v) containing SYBR Safe DNA Gel Stain (Invitrogen Co., Carlsbad, USA) run in $0.5 \mathrm{X}$ TBE buffer at $90 \mathrm{~V}$ for $45 \mathrm{~min}$.

\section{Centrifugation Enrichment Technique (C)}

Samples were thawed on ice, and pairs of swabs from the same patient (1 left, 1 right) were briefly vortexed to release bacterial cells from the swab matrix into the RNAlater ${ }^{\circledast}$ solution. Both swabs were removed from the microcentrifuge tube, and the RNAlater ${ }^{\circledast}$ solution was centrifuged for $3 \mathrm{~min}$ at $500 \mathrm{x} \mathrm{g}$ in order to pellet the large (heavy) human cells while leaving smaller, microbial cells in the supernatant. The supernatant was removed into a fresh microcentrifuge tube, which was then centrifuged for $7 \mathrm{~min}$ at $8000 \mathrm{xg}$ to pellet microbial cells. The supernatant was discarded, and pelleted cells were resuspended in $600 \mu \mathrm{L}$ of Buffer RLT Plus. DNA was extracted from the resuspended pellet as described above. DNA yield, quality and integrity of extracted DNA were determined as described above.

\section{NEBNext ${ }^{\oplus}$ Microbiome DNA Enrichment Kit (NB)}

The NEBNext ${ }^{\oplus}$ Microbiome DNA Enrichment Kit selectively removes human DNA from samples by binding double-stranded DNA containing 5-methyl CpG dinucleotides (which are common in vertebrate DNA) to a magnetic bead ${ }^{(17)}$. Briefly, samples were thawed on ice, and DNA was extracted from pairs of swabs from the same patient ( 1 left, 1 right) using the Qiagen ${ }^{\circledR}$ AllPrep DNA/RNA Mini Kit as described above. Total DNA concentration was calculated and $2 \mu \mathrm{g}$ input DNA was used for enrichment of microbial DNA using the NEBNext ${ }^{\oplus}$ Microbiome DNA Enrichment Kit, following the manufacturer's instructions (New England BioLabs ${ }^{\circledast}$ Inc., Thermo Fisher Scientific, Auckland, New Zealand). All volumes were adjusted to allow for $2 \mu \mathrm{g}$ of input
DNA for each of the three samples.

After microbial and host DNA were selectively captured using the NEBNext ${ }^{\oplus}$ Microbiome DNA Enrichment Kit, Agencourt AMPure XP Bead Clean-up (Beckman Coulter Inc., Brea, CA, USA) was used to purify the enriched samples. Briefly, all sample volumes were split into $160 \mu \mathrm{L}$ volumes, if necessary, and $1.8 \mathrm{X}$ volumes of AMPure beads were added to each sample. After several ethanol wash steps, DNA was eluted from the magnetic beads in 15-25 $\mu \mathrm{L}$ (depending on initial input volume) of TE Buffer, pH 7.5.

\section{Whole genome amplification ('WGA')}

Samples were first subjected to one of the two enrichment techniques, or originated from the no-enrichment control DNA extraction. The Qiagen ${ }^{\circledast}$ REPLI-g Mini Kit (Bio-Strategy LTD., Auckland, New Zealand) was used to amplify $5 \mu \mathrm{L}$ of template DNA from each sample according to the manufacturer's instructions. For each reaction, a positive control of E. coli genomic DNA and a negative control of PCR-grade water was used. Quality, integrity and yield of amplified DNA were assessed as previously described.

\section{Sequencing preparation \\ PCR amplification and Illumina sequencing}

In order to compare the recovery of bacterial community composition profiles based on metagenomic sequencing to those based on the usual approach employed by CRS researchers (i.e. 16S rRNA gene-targeted sequencing), we amplified the V3-V4 hypervariable region of the bacterial 16S rRNA gene for each sample in this project. Amplifications were carried out as described previously ${ }^{(9)}$, with minor adjustments (Additional file 2). The triplicate negative extractions from the DNA extraction kits were amplified and verified for lack of contamination.

Replicate PCR products from each sample were pooled and purified using Agencourt AMPure beads according to manufacturer instructions. Bacterial 16S rRNA gene amplicons were submitted to New Zealand Genomics Limited for library preparation using a dual-indexing approach with Nextera technology and sequencing ( 2 × 300 bp, paired-end) on the Illumina MiSeq. Metagenomic samples were submitted as is to New Zealand Genomics Limited for Thruplex DNA library preparation and sequencing (2 x 125 bp, paired-end) on one lane of the Illumina HiSeq.

\section{Data analyses}

\section{Bacterial 16S rRNA gene sequence analysis}

Bioinformatic processing of amplicon sequencing data involved a combination of USEARCH (version 7.0.1090, 64-bit built for Linux) and QIIME version 1.8 (Additional file 2) ${ }^{(32,33)}$. Samples were rarefied to 1,678 sequences, and rarefied tables were used for all downstream analyses. Alpha diversity measures Chao1, Shannon, Simpson and observed species (OTUs), and a Bray-Curtis dissimilarity matrix were assessed and generated using QIIME. 


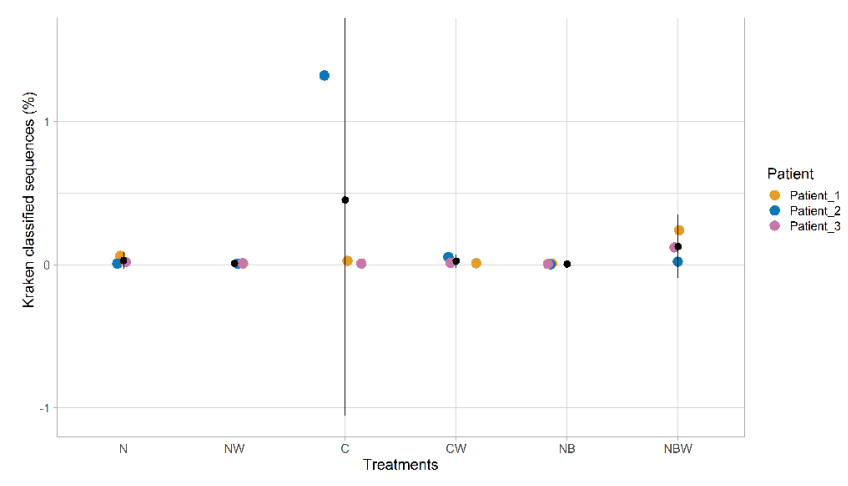

Figure 2. Proportion of metagenomic sequences that were classified using the Kraken database after quality filtering and removal of humanaligned sequences. Mean values are indicated by black dots and standard deviations are defined by the extent of the black lines.

PRIMER6 version 6.1.13 was used to identify microbial community similarities between groups of samples based on enrichment method for each type of sequencing data (SIMPER), to assess variation within the data due to inter-individual variation and enrichment method (PERMANOVA), and to analyse patterns in microbial community composition between methods for both amplicon and metagenomics datasets (ANOSIM) ${ }^{(34)}$. Multivariate dispersion (MVDISP) was used to quantify relative multivariate variability between methods.

\section{Metagenomic sequencing analysis}

Raw reads were quality filtered using trimmomatic v0.33 with default settings ${ }^{(35)}$. Reads that aligned to the human genome were removed, and the remaining sequences from each sample were assigned taxonomy using Kraken v0.10.5-beta and a custom-built database compiled with all archaeal, fungal, bacterial, viral and protozoan genomes available on NCBI as of September 13, 2016 (Additional file 2) ${ }^{(36)}$. The Bracken bioinformatics program was used to calculate abundances from Kraken-assigned taxonomy at the phylum, family, and species levels, and these data were used for all downstream analyses (Additional file 2) ${ }^{(37)}$.

\section{Population genome assembly and binning}

After quality filtering and removal of human DNA from the metagenomic dataset, high-quality sequences from all samples were pooled, assembled, and assessed using SPAdes v3.7.1 (38), BamM v1.7.3 (https://github.com/Ecogenomics/BamM), GroopM v0.3.4 ${ }^{(39)}$, and CheckM v1.0.7 ${ }^{(40)}$ (Additional file 2). A single nearcomplete genome ( $97.35 \%$ complete) with no contamination was reconstructed. This population bin, identified as the bacterium Propionibacterium acnes, was examined for contigs with abnormal coverage or composition profile using RefineM v0.0.13 (https://github.com/dparks1134/refinem), then gaps filled and the refined genome bin assembled into scaffolds using FinishM (https://github.com/wwood/finishm). Taxonomic identification and phylogenetic inference were performed using Genome Taxonomy Database ${ }^{(41)}$ and FastTree v2.1.9 ${ }^{(42)}$, respectively (Additional file 2). Gene prediction, annotation and metabolic reconstruction for the recovered $P$. acnes genome were carried out using Rapid Annotations using Subsystems Technology (RAST) online server and all default settings ${ }^{(43)}$. The RAST server was used to compare the recovered $P$. acnes genome to that of its closest phylogenetic neighbour, P. acnes strain KPA171202.

\section{Results}

Total DNA was extracted from 18 sino-nasal middle meatus swab samples ( 3 patients $\times 6$ methods) using a variety of bacterial enrichment techniques ( $N, N+W G A, C, C+W G A, N B$, NB+WGA) (Figure 1). Bacterial 16S rRNA gene amplicons were sequenced using Illumina MiSeq, and metagenomic DNA samples were subjected to shotgun metagenomic sequencing using Illumina HiSeq. Quality filtering and rarefaction of MiSeqderived reads resulted in 355,080 16S rRNA gene sequences from 14 samples. Four samples, including the centrifugationtreated sample from Patient 2, and all samples treated using the NB enrichment method, resulted in insufficient sequences for downstream analyses. Metagenomic sequencing returned a total of 539,433,708 sequences across 18 samples. Quality filtering and removal of host-associated DNA from the HiSeq-derived metagenome samples resulted in a total of 611,151 Krakenclassified sequences ( $<1 \%$ of total sequences).

Efficacy of enrichment methods: Metagenomic data Method $\mathrm{C}$ recovered the highest mean percentage of microbial sequences (mean $0.45 \% \pm$ SD 0.75 ); however, this method did not yield reproducible results (coefficient of variation $(C V)=166 \%$ ) (Figure 2). All other methods had CV values less than $100 \%$, which indicate reproducibility (method $\mathrm{N}=0.03 \%$ $\pm 0.029, \mathrm{CV}=95.20 \%$; method $\mathrm{N}+\mathrm{WGA}=0.0093 \% \pm 0.0016$, $\mathrm{CV}=17.40 \%$; method $\mathrm{C}+\mathrm{WGA}=0.026 \% \pm 0.024, \mathrm{CV}=90.54$; method NB $=0.0064 \% \pm 0.0028, C V=44.36 \%$; method NB+WGA $=0.13 \pm 0.11 \%, C V=85.97 \%)$. The Kruskal-Wallis group test revealed no significant differences among any of the enrichment methods regarding the proportion of recovered microbial sequence reads $(p=0.056)$.

\section{Effect of DNA enrichment method on profiling of microbial} community structure

Microbial communities from both amplicon and metagenomic datasets were dominated by the bacterial phyla Actinobacteria, Firmicutes, and Proteobacteria. Metagenomic sequencing revealed a large relative abundance of the archaeal phylum Euryarchaeota, including members of the family Methanobacteriaceae. On average, Propionibacterium acnes, Staphylococcus aureus, Methanobacterium formicicum, Salmonella enterica and Staphylococcus epidermidis were the five species that dominated 

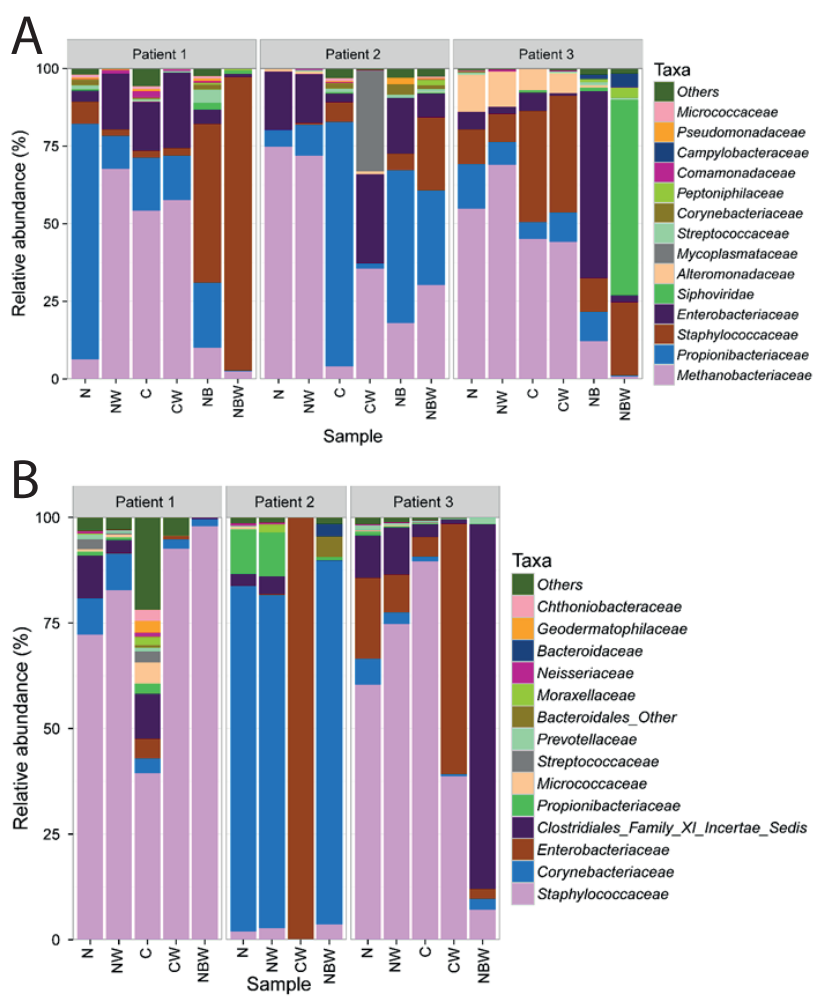

Figure 3. Relative abundance taxa plot of the top 14 family level taxonclassified sequences from (A) Metagenomic sequencing ( $n=18)$, and (B) Bacterial 16S rRNA gene amplicon sequencing $(n=14)$.

the metagenome datasets. Evaluation of community composition at family level revealed differences in relative abundances between types of sequencing and enrichment methods (Figure 3). Differences in community composition between bacterial amplicon and metagenomic sequencing was expected due to the targeted nature of $16 \mathrm{~S}$ rRNA gene sequencing to bacteria. The metagenomic sequencing results indicated the presence of over 500 species, including a variety of archaea, viruses and bacteriophages, bacteria, and fungi (Additional file 3). Relatively few types of fungi (all belonging to division Ascomycota) were recovered, and these were only in the centrifugation sample from Patient 2. Furthermore, metagenomic sequencing recovered 39 species of Corynebacterium, 5 species of Propionibacterium, and 12 species of Staphylococcus (Additional file 4). Several types of double-stranded DNA viruses were also detected, the majority of which were members of the viral family Papillomaviridae and many of which were found only in Patient 2 (Additional file 3). Spearman correlation coefficients were used to compute the correlation between amplicon and metagenomic sequencing samples for only family-assigned bacterial taxa (all viral, fungal, and members of the phylum Euryarchaeota were removed from the metagenomic dataset) ( $r s=0.38, p=0.001)$. These results suggest that the two types of sequencing recover dissimilar microbial community profiles. This may be due to the relatively few sequencing reads from metagenomic sequencing; however, we encourage future studies to incorporate both amplicon and metagenomic sequencing, where possible, for further comparisons.

\section{Effect of DNA enrichment method on comparisons of beta- diversity} PERMANOVA results from amplicon and metagenomic (for species and family-level taxa) Bray-Curtis dissimilarity matrices revealed no significant influence of enrichment methods on variation in either MiSeq or HiSeq datasets ( $p>0.05$ ). PERMANOVA results from the amplicon data suggested that differences between patients' bacterial diversity contributed $36.5 \%$ to the variation in this dataset $(p=0.001, R 2=0.365)$. This result was not evident in the metagenomic PERMANOVA results, however. These clustering patterns are not surprising considering previous research reporting the heavy influence of inter-subject variability ${ }^{(8)}$.

Both the metagenomics and amplicon approaches revealed similar bacterial community compositions in regards to the effect of enrichment method on beta-diversity (Figure 4). In the metagenomic dataset, analysis of similarity (ANOSIM) pair-wise tests between all methods and the no-enrichment control revealed no significant differences. This finding is visualized in the nMDS, with the no-enrichment control samples positioned in the center of all samples (Figure 4A). Comparisons of variability between methods, using MVDISP, revealed that the NW samples clustered closest to the N samples, and the NBW method showed the largest dispersion from the no-enrichment control samples, suggesting this method recovers slightly (although not significantly) different microbial community compositions. Similarity percentages (SIMPER) results revealed samples treated with the NBW method were the most dissimilar to the no-treatment control (average dissimilarity $=71 \%$ ), and samples from the NW method were the most similar to the no-treatment control (average dissimilarity $=44.6 \%$ ).

Samples tended to cluster more by patient in the amplicon sequencing nMDS plot when compared to the metagenomic nMDS. Similar to the metagenomic dataset, ANOSIM results revealed no significant differences between microbial community compositions recovered by the different methods. However, samples treated using the CW method clustered further away from the no-enrichment control samples (Figure 4B). SIMPER results suggested samples treated with this method (CW) were most dissimilar to the no-treatment control (average dissimilarity $=78.5 \%$ ), and samples from the NW method were the most similar to the no-treatment control (average dissimilarity = $45.6 \%)$.

\section{Propionibacterium acnes genome}

Phylogenomic inference of the concatenated marker genes 

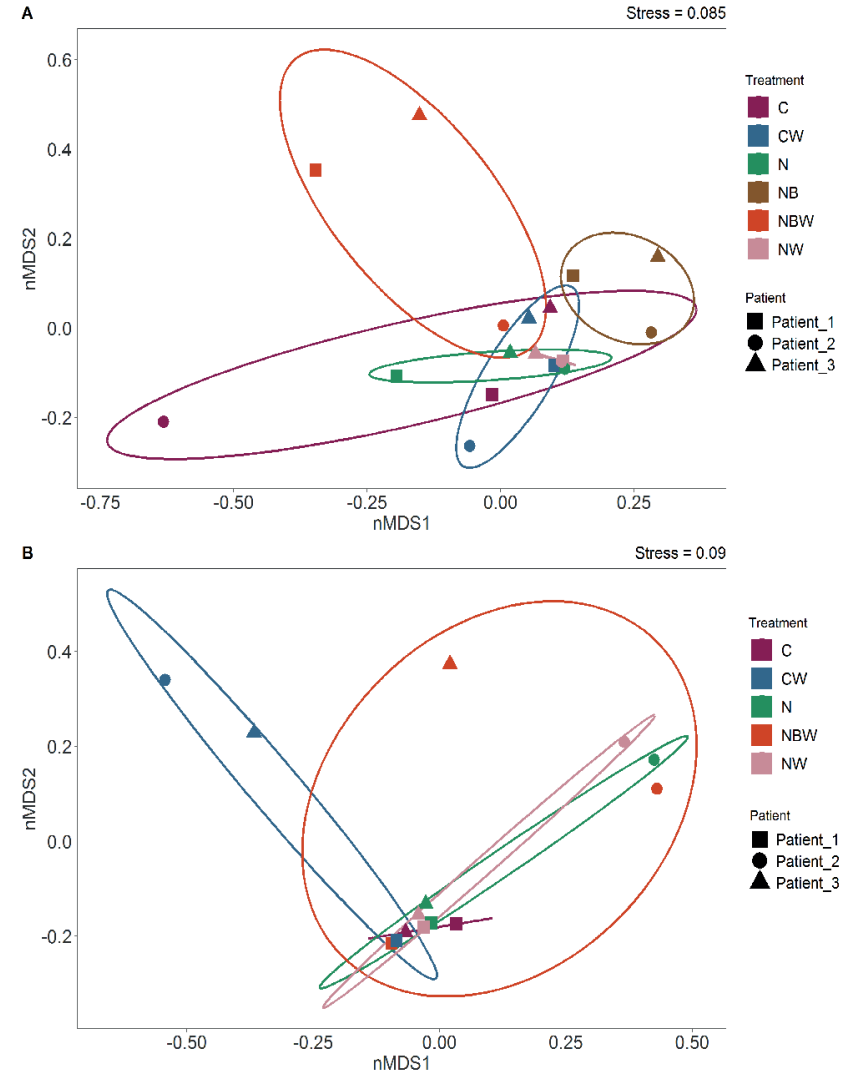

Figure 4. Non-metric multidimensional scaling (nMDS) plot of (A) Metagenomic sequencing data, (B) Bacterial 16S rRNA gene targeted amplicon data. Patients are represented by shapes, and treatment categories are represented by colours. Ellipses represent the mean of the description coordinates at the centre, and the dispersion of the ellipses were calculated using the standard error of the weighted average of covariance matrix group scores.

identified the genome as Propionibacterium acnes, a common skin commensal bacterium. The recovered $P$. acnes genome is $2,588,344 \mathrm{bp}$, with $60.0 \% \mathrm{GC}$ content, and contains 2,510 coding sequences. A comparative analysis to characterize the pan-genome of 69 P. acnes isolates ( 67 were isolated from human skin) reported an average genome size of $2.5 \mathrm{Mb}, 60 \% \mathrm{GC}$ content, and 2,626 open reading frames ${ }^{(44)}$. The recovered $P$. acnes genome formed a strong supported monophyletic clade with $P$. acnes strains KPA171202 (GenBank assembly GCF_000008345.1, ${ }^{(45)}$ ) and JCM 18 (82.96\% complete, 0.78\% contamination), (GenBank assembly GB_GCA_000521405.1) (Additional file 5).

Annotation and pathway mapping of protein-coding genes (CDs) classified into subsystem categories revealed that a majority of CDs belonged to amino acid and derivative production, followed by genes coding for carbohydrates (Additional file 6). Due to incompleteness of the recovered $P$. acnes genome, the apparent presence or absence of a single copy or particular coding genes should be regarded with caution. Comparisons of metabolic reconstruction between our recovered $P$. acnes genome and the genome of $P$. acnes strain KPA171202, isolated from human skin, revealed 112 genes that are present in the CRS $P$. acnes genome but not the KPA171202 reference strain (Additional file 7). A majority of the genes unique to the recovered $P$. acnes genome were related to carbohydrate production.

\section{Discussion}

The results from this methods study suggest that the enrichment techniques unpredictably alter microbial community profiles when comparing them to non-treated samples. Despite these effects and the ineffective removal of contaminating human DNA, a diverse range of viral, fungal, archaeal and bacterial species were reported, as well as a near-complete genome of the bacterium Propionibacterium acnes.

\section{Microbial enrichment techniques}

The application of metagenomic sequencing to sino-nasal research is promising, but greater sequencing depths will be required to garner useful information. In this study, the centrifugation method was the most promising enrichment method as it recovered the largest proportion of microbial sequences, however it was inconsistent between samples. Commercial tools, such as the NEBNext ${ }^{\oplus}$ Microbiome DNA Enrichment Kit are specifically designed to remove human DNA, however we observed no significant increase in the proportion of microbial assigned sequences when compared with the no treatment control. Furthermore, the incorporation of WGA MDA prior to sequencing did not improve the recovery of microbial sequences in any of the enrichment methods.

This study has several limitations. First, the results from this study provide limited insights into the function of the microbiome in CRS due to small sample sizes and the lack of healthy controls. Additionally, future metagenomic studies with low biomass samples should include sequencing results from negative controls throughout the experiment to assess contamination in low biomass samples ${ }^{(46)}$. Other enrichment techniques with sino-nasal samples should be explored, including modifying the sample type and testing a wider range of methods. For example, mucous lavage samples provide more starting volume than swab samples and multiple enrichments from the same starting material may be applied. Finally, where possible, we recommend processing samples fresh from collection to prevent lysing of human cells and the uncontrolled release of human DNA which may affect enrichment outcomes.

The application of metagenomic sequencing to CRS research will first have to overcome the substantial challenge of the overwhelming proportion of host-associated DNA. Careful consideration of enrichment techniques more generally, regarding sample type (tissue versus swab versus lavage), biases and limi- 
tations of enrichment methods, costs (sample processing and sequencing), as well as desired outcomes, is necessary. Based on these results, we recommend sequencing fewer sino-nasal derived samples per metagenomic sequencing run to increase the depth of sequencing without altering in situ microbial community structure.

\section{Microbial composition revealed by metagenomic sequen- cing}

The bacterial genera Corynebacterium, Propionibacterium, and Staphylococcus are frequent colonizers of the sino-nasal cavity, however their role in health and contribution to CRS pathogenesis remains unclear ${ }^{(47-49)}$. High species- and strain-level variability of these genera typically goes uncharacterized due to the limited taxonomic resolution of 165 rRNA gene-targeted sequencing. Future studies should focus on characterizing the presence of these key bacteria at increased resolution in patients with and without CRS.

The results from this study identified 55 Propionibacterium and 14 Staphylococcus phages. The extensive diversity and presence of bacteriophages, especially related to the genera Propionibacterium and Staphylococcus, is consistent with results from a previous metagenomic study which reported a significant abundance of viral DNA, including bacteriophages, in the nares of healthy subjects when compared to other skin sites (mean relative abundance $51.0 \% \pm 11.8$ S.E.) ${ }^{(15)}$. The presence and diversity of dsDNA viruses in our results are consistent with findings from others ${ }^{(50,51)}$.

High recovered proportions of the methanogenic archaeal species Methanobacterium formicicum, belonging to the family Methanobacteriaceae, were unexpected and are not well studied elsewhere in the sino-nasal literature. Whether such high relative abundances are typical for the sino-nasal cavity during health or disease should be addressed in future studies. Additionally, such low levels of fungi were in agreement with the pilot data, yet unexpected, as previous amplicon studies have identified several fungal species in both healthy patients and those with CRS ${ }^{(52,53)}$. Taken together, these results suggest that fungi are present in the sino-nasal cavity, although at very low relative abundances, and that amplification of fungal DNA may be necessary to capture total diversity.

Bacterial taxa dominated the reference database, with lower representation of fungal, archaeal and viral genomes, so it is likely that these latter microbes are underrepresented in our results. Additionally, the general lack of metagenomic and viral data from patients with CRS makes it difficult to contextualize the results from this study, which included data from only three CRS patients. A study examining the eukaryotic doublestranded DNA and single-stranded DNA viruses from the Human Microbiome Project cohort ${ }^{(50)}$ reported unique viral fingerprints among subjects (much like host-associated bacterial communities), a combination of stable and transient viral carriage, and an average diversity of 5.5 viruses per individual. Of clinical importance, carriage of a known disease-causing virus was not associated with symptoms or apparent clinical consequences (50), which may suggest that onset of disease is an interaction of events involving the host immune system, bacterial and active viral infection, and fungal communities. The CRS-associated virome warrants further investigation, with the few published studies being somewhat contradictory ${ }^{(54,55)}$.

\section{Functional insights from metagenomic sequencing}

Although only negligible improvements were made to the recovery of microbial DNA, we nevertheless sought to explore the potential of these data to deliver useful genomic insights. We succeeded in reconstructing a near-complete Propionibacterium acnes genome ( $97.35 \%$ complete, $0 \%$ contamination). Interestingly, our $P$. acnes genome contains the cas 1 gene, which is part of the clustered regularly interspaced short palindromic repeats (CRISPR)/Cas locus which helps to protect the bacterium from bacteriophages and other mobile genetic elements ${ }^{(56)}$. The presence of CRISPR/Cas genes in P. acnes is not uncommon, but is typically identified in type II $P$. acnes strains ${ }^{(44,45)}$. If our genome is in fact a type II strain, it may be functionally more similar to P. acnes ATCC_11828 strain. Some evidence suggests people carry different $P$. acnes strains in the same environment, and the role of $P$. acnes in CRS, and the sino-nasal cavity more generally, should be investigated further.

\section{Conclusion}

Existing research in CRS microbiology is limited to culture-based and gene-targeted approaches. Expanding our knowledge base from identifying which bacteria are present in the sinuses towards a view which includes archaeal, fungal, and viral species, and describing their functional importance and impact on health status, is the next logical step for studying CRS pathogenesis. Taken together, the results from this study support the application of metagenomic sequencing techniques in the study of microbial communities associated with CRS, however we do not recommend enriching samples for microbial DNA using the techniques described here. We encourage continued research that focuses on limiting the proportion of recovered human DNA in order to increase the resolution of in situ microbial communities.

\section{Acknowledgements}

The authors would like to thank the patients who took part in this study. Many thanks to Philip Hugenholtz and ACE for computing support, David Wood for his help operating RemoveM, and Brian Kemish for providing computing support. The research in this study was supported by The Garnett Passe and 
Rodney Williams Memorial Foundation Charitable Trust Fund. Sequencing data are available upon request.

\section{Authorship contribution}

BWM analysed and interpreted the data and wrote the manuscript. DWW helped with analysis of the dataset. KB, MWT helped with study design and interpretation of the dataset. RGD collec- ted the samples and contributed to interpretation of the results. All authors read and approved the final manuscript.

\section{Conflict of interest}

The authors declare that this research was conducted in the absence of any commercial or financial relationships that could be construed as a potential conflict of interest.

\section{References}

1. The Human Microbiome Project Consortium. Structure, function and diversity of the healthy human microbiome. Nature.;486(7402):207-14.

2. Lloyd-Price J, Mahurkar A, Rahnavard G, Crabtree J, Orvis J, Hall AB, et al. Strains, functions and dynamics in the expanded Human Microbiome Project. Nature. 2017;550(7674):61-6.

3. Nielsen HB, Almeida M, Juncker AS, Rasmussen S, Li J, Sunagawa S, et al. Identification and assembly of genomes and genetic elements in complex metagenomic samples without using reference genomes. Nat Biotechnol. 2014;32(8)

4. Bhattacharyya N. Incremental health care utilization and expenditures for chronic rhinosinusitis in the United States. Ann Otol Rhinol Laryngol. 2011;120(7):423-7.

5. Fokkens WJ, Lund VJ, Mullol J, Bachert C Alobid I, Baroody F. European Position Paper on Rhinosinusitus and Nasal Polys 2012. Rhinology. 2012;(23):1-20.

6. Orlandi RR, Kingdom TT, Hwang PH, Smith $\mathrm{TL}$, Alt JA, Baroody FM, et al. International Consensus Statement on Allergy and Rhinology: Rhinosinusitis. Int Forum Allergy Rhinol. 2016;6(November 2015):S22-209.

7. Abreu NA, Nagalingam NA, Song $Y$, Roediger FC, Pletcher SD, Goldberg AN, et al. Sinus microbiome diversity depletion and Corynebacterium tuberculostearicum enrichment mediates rhinosinusitis. Sci Transl Med. 2012;4(151):151ra24.

8. Biswas K, Hoggard M, Jain R, Taylor MW, Douglas RG. The nasal microbiota in health and disease: variation within and between subjects. Front Microbiol. 2015 Jan;9(March):134.

9. Hoggard M, Biswas K, Zoing M, Wagner Mackenzie B, Taylor MW, Douglas RG. Evidence of microbiota dysbiosis in chronic rhinosinusitis. Int Forum Allergy Rhinol. 2016;7(3):7-11.

10. Ramakrishnan VR, Hauser LJ, Feazel LM, Ir D, Robertson CE, Frank DN. Sinus microbiota varies among chronic rhinosinusitis phenotypes and predicts surgical outcome. J Allergy Clin Immunol. 2015 Aug;136(2):33442.e1.

11. Hoggard M, Mackenzie BW, Jain R, Taylor MW, Biswas K, Douglas RG. Chronic rhinosinusitis and the evolving understanding of microbial ecology in chronic inflammatory mucosal disease. Clin Microbiol Rev.
2017;30(1):321-48

12. Wagner Mackenzie B, Waite DW, Hoggard M, Douglas RG, Taylor MW, Biswas K Bacterial community collapse: A metaanalysis of the sinonasal microbiota in chronic rhinosinusitis. Environ Microbiol. 2016:19:381-92.

13. Blattner FR, Plunkett G, Bloch CA, Perna $N T$, Burland $V$, Riley $M$, et al. The complete genome sequence of Escherichia coli K-12 Sci Mag. 1997;277(September):1453-62.

14. Venter JC, Adams MDM, Myers EEW, Li PW, Mural RJ, Sutton GG, et al. The sequence of the human genome. Science. 2001;291(5507):1304-51.

15. Oh J, Byrd AL, Deming C, Conlan S Barnabas B, Blakesley R, et al. Biogeography and individuality shape function in the human skin metagenome. Nature. 2014:514(7520):59.

16. Wylie KM, Mihindukulasuriya $\mathrm{K}$ a, Zhou $\mathrm{Y}$, Sodergren E, Storch G a, Weinstock GM. Metagenomic analysis of double-stranded DNA viruses in healthy adults. BMC Biol. 2014;12:71.

17. Feehery GR, Yigit E, Oyola SO, Langhorst BW Schmidt VT, Stewart FJ, et al. A method for selectively enriching microbial DNA from contaminating vertebrate host DNA. PLoS One. 2013 Jan;8(10):e76096.

18. Bright A, Tewhey R, Abeles S, Chuquiyaur R, Llanos-Cuentas A, Ferreira MU, et al. Whole genome sequencing analysis of Plasmodium vivax using whole genome capture. BMC Genomics. 2012;13(1):262

19. Burke RM, McKenna JP, Cox C, Coyle P V., Shields MD, Fairley DJ. A comparison of different pre-lysis methods and extraction kits for recovery of Streptococcus agalacticae (Lancefield group B Streptococcus) DNA from whole blood. J Microbiol Methods 2016:129:103-8.

20. Thurber R V., Haynes M, Breitbart M, Wegley L, Rohwer F. Laboratory procedures to generate viral metagenomes. Nat Protoc. 2009;4(4):470-83.

21. Marotz CA, Sanders JG, Zuniga C, Zaramela LS, Knight R, Zengler K. Improving saliva shotgun metagenomics by chemical host DNA depletion. Microbiome. 2018;6(1):1-9.

22. Clarke EL, Lauder AP, Hofstaedter CE, Hwang Y, Fitzgerald AS, Imai I, et al. Microbial lineages in sarcoidosis a metagenomic analysis tailored for lowmicrobial content samples. Am J Respir Crit Care Med. 2018;197(2):225-34.
23. Horz HP, Scheer S, Vianna ME, Conrads G. New methods for selective isolation of bacterial DNA from human clinical specimens. Anaerobe. 2010;16(1):47-53.

24. Thoendel M, Jeraldo PR, GreenwoodQuaintance KE, Yao JZ, Chia N, Hanssen $A D$, et al. Comparison of microbial DNA enrichment tools for metagenomic whole genome sequencing. J Microbiol Methods. 2016;127:141-5.

25. Hasan MR, Rawat $A$, Tang $P$, Jithesh $P$ V Thomas E, Tan R, et al. Depletion of human DNA in spiked clinical specimens to improve the sensitivity of pathogen detection by next generation sequencing. J Clin Microbiol. 2016:54(January):JCM.03050-15-.

26. Votintseva AA, Pankhurst LJ, Anson LW, Morgan MR, Gascoyne-Binzi D, Walker TM, et al. Mycobacterial DNA extraction for whole-genome sequencing from early positive liquid (MGIT) cultures. J Clin Microbiol 2015;53(4):1137-43.

27. Glassing A, Dowd SE, Galandiuk S, Davis B, Jorden JR, Chiodini RJ. Changes in 16s RNA gene microbial community profiling by concentration of prokaryotic DNA. J Microbiol Methods. 2015;119:239-42.

28. Leo S, Gaïa N, Ruppé E, Emonet S, Girard M, Lazarevic $V$, et al. Detection of bacterial pathogens from broncho-alveolar lavage by next-generation sequencing. Int J Mol Sci. 2017;18(9):2011.

29. Oyola SO, Gu Y, Manske M, Otto TD, O'Brien J, Alcock D, et al. Efficient depletion of host DNA contamination in malaria clinical sequencing. J Clin Microbiol. 2013;51(3):745-51.

30. Liu P, Fang X, Feng Z, Guo Y-M, Peng R-J, Liu $T$, et al. Direct sequencing and characterization of a clinical isolate of Epstein-Barr virus from nasopharyngeal carcinoma tissue by using next-generation sequencing technology. J Virol. 2011;85(21):11291-9.

31. Loonen AJM, Bos MP, van Meerbergen $B$ Neerken S, Catsburg A, Dobbelaer I, et al. Comparison of pathogen DNA isolation methods from large volumes of whole blood to improve molecular diagnosis of bloodstream infections. PLoS One. 2013;8(8):1-7.

32. Edgar RC. UPARSE: highly accurate OTU sequences from microbial amplicon reads. Nat Methods. 2013 Oct;10(10):996-8.

33. Caporaso JG, Kuczynski J, Stombaugh J, Bittinger K, Bushman FD, Costello EK, et al. QIIME allows analysis of high-throughput 
community sequencing data. Nat Methods 2010;7(5):335

34. Anderson MJ, Gorley RN, Clarke KR PERMANOVA+ for PRIMER: Guide to Software and Statistical Methods. Plymouth, U.K.: PRIMER-E Ltd; 2008.

35. Bolger AM, Lohse M, Usadel B. Trimmomatic: A flexible trimmer for Illumina sequence data. Bioinformatics. 2014;30:2114

36. Wood DE, Salzberg SL. Kraken: ultrafast metagenomic sequence classification using exact alignments. Genome Biol. 2014;15(3).

37. Lu J, Breitwieser FP, Thielen P, Salzberg SL. Bracken: Estimating species abundance in metagenomics data. bioRxiv. 2016;1-14.

38. Bankevich A, Nurk S, Antipov D, Gurevich AA, Dvorkin M, Kulikov AS, et al. SPAdes: a new genome assembly algorithm and its applications to single-cell sequencing. J Comput Biol. 2012;19(5):455-77.

39. Imelfort M, Parks D, Woodcroft BJ, Dennis P, Hugenholtz P, Tyson GW. GroopM: An automated tool for the recovery of population genomes from related metagenomes. PeerJ. 2014;2:e409v1.

40. Parks $D H$, Imelfort $M$, Skennerton $C T$, Hugenholtz P, Tyson GW. CheckM: assessing the quality of microbial genomes recovered from isolates, single cells, and metagenomes. Genome Res. 2015;25(7):1043-55.

41. Parks DH, Chuvochina M, Waite DW, Rinke C, Skarshewski A, Chaumeil P-A, et al. A proposal for a standardized bacterial taxonomy based on genome phylogeny. bioRxiv. 2018. doi: https://doi.org/10.1101/256800.

42. Price MN, Dehal PS, Arkin AP. FastTree: computing large minimum evolution trees with profiles instead of a distance matrix. Mol Biol Evol. 2009 Jul;26(7):1641-50.

43. Aziz RK, Bartels D, Best A, DeJongh M, Disz
T, Edwards RA, et al. The RAST Server: Rapid annotations using subsystems technology. BMC Genomics. 2008;9:1-15.

44. Tomida S, Nguyen L, Chiu B, Analyses $C G$, Its R, Diversity $G$, et al. Pan-genome and comparative genome analyses of Propionibacterium acnes reveal its genomic diversity in the healthy and diseased human skin microbiome. MBio. 2013;4(3):e00003-13.

45. Brüggemann $H$, Lomholt HB, Tettelin H, Kilian M. CRISPR/cas loci of type II Propionibacterium acnes confer immunity against acquisition of mobile elements present in type I P. acnes. PLoS One. 2012;7(3):e34171.

46. Salter SJ, Cox MJ, Turek EM, Calus ST, Cookson WO, Moffatt MF, et al. Reagent and laboratory contamination can critically impact sequence-based microbiome analyses. BMC Biol. 2014 Nov;12(1):87.

47. Liu CM, Soldanova K, Nordstrom L, Dwan MG, Moss OL, Contente-Cuomo TL, et al. Medical therapy reduces microbiota diversity and evenness in surgically recalcitrant chronic rhinosinusitis. Int Forum Allergy Rhinol. 2013 Oct;3(10):775-81.

48. Kaspar U, Kriegeskorte A, Schubert T, Peters G, Rudack C, Pieper DH, et al. The culturome of the human nose habitats reveals individual bacterial fingerprint patterns. Environ Microbiol. 2015 Apr 28;18(7):2130-42.

49. Ramakrishnan VR, Frank DN. Impact of cigarette smoking on the middle meatus microbiome in health and chronic rhinosinusitis. Int Forum Allergy Rhinol. 2015 Aug 14:5(11):981-9.

50. Wylie KM, Weinstock GM, Storch GA. Emerging view of the human virome. Transl Res. 2012;160(4):283-90

51. Willner D, Furlan M, Haynes M, Schmieder R,
Angly FE, Silva J, et al. Metagenomic analysis of respiratory tract DNA viral communities in cystic fibrosis and non-cystic fibrosis individuals. PLoS One. 2009;4(10):e7370.

52. Zhao YC, Bassiouni A, Tanjararak K, Vreugde S, Wormald P-J, James Psaltis A. Role of fungi in chronic rhinosinusitis through ITS sequencing. Laryngoscope. 2017;1-7.

53. Cleland EJ, Bassioni A, Boase S, Dowd S, Vreugde $S$, Wormald PJ. The fungal microbiome in chronic rhinosinusitis: Richness, diversity, postoperative changes and patient outcomes. Int Forum Allergy Rhinol. 2014;4(4):259-65.

54. Cho GS, Moon BJ, Lee BJ, Gong CH, Kim $\mathrm{NH}$, Kim YS, et al. High rates of detection of respiratory viruses in the nasal washes and mucosae of patients with chronic rhinosinusitis. J Clin Microbiol. 2013:51(3):979-84.

55. Wood AJ, Antoszewska H, Fraser J, Douglas RG. Is chronic rhinosinusitis caused by persistent respiratory virus infection? Int Forum Allergy Rhinol. 2011;1(2):95-100.

56. Horvath P, Barrangou R. CRISPR/Cas, the immune system of bacteria and archaea. Science. 2010;327(5962):167-70.

Professor Richard G. Douglas

School of Medicine

Department of Surgery

The University of Auckland

Auckland

New Zealand

E-mail:

Richard.douglas@auckland.ac.nz 


\section{Additional files}

Table S1. Baseline characteristics of patients at the time of surgery and sample collection.

\begin{tabular}{|c|c|c|c|c|c|c|c|c|c|}
\hline Patient & Sex & Age & Ethnicity & Diagnosis & Procedure & Smoker & $\begin{array}{c}\text { Asthma/ } \\
\text { Aspirin } \\
\text { Sensitivity }\end{array}$ & Antibiotics & Prednisone \\
\hline 1 & M & 59 & NZE & CRS & FHFESSa, ITb & Ex & No & No & No \\
\hline 2 & M & 30 & NZE & CRS & FHFESS, Sc, IT & Ex & No & No & No \\
\hline 3 & $M$ & 55 & NZE & CRS & FHFESS, FDd & No & No & No & No \\
\hline
\end{tabular}

aFHFESS: full-house functional endoscopic sinus surgery

bIT: indicates removal of inferior turbinates

cS: septoplasty procedure. Used to surgically modify the nasal septal cartilage.

dFD: frontal drill out, also known as Lothrop procedure. Used in revision cases to create the largest possible frontal ostium.

\section{Supplementary methods}

\section{Sequencing preparation}

PCR amplification and Illumina sequencing

In order to compare the recovery of bacterial community composition profiles based on metagenomic sequencing to those based on the usual approach employed by CRS researchers (i.e. 16S rRNA gene-targeted sequencing), we amplified the V3-V4 hypervariable region of the bacterial 16S rRNA gene for each sample in this project. Briefly, up to $3 \mu \mathrm{L}$ of template DNA from each sample was added to the PCR master mix, and as many as three PCR replicates were completed for each sample in order to generate sufficient amplicon product for sequencing. The triplicate negative extractions from the DNA extraction kits were amplified and verified for lack of contamination.

Replicate PCR products from each sample were pooled and purified using Agencourt AMPure beads according to manufacturer instructions. PCR products were quantified fluorometrically using the High Sensitivity (HS) kit on the Qubit ${ }^{\circledR}$ Fluorometer 1.0 (Invitrogen Co., Carlsbad, CA, USA) and qualitatively assessed using the Agilent High Sensitivity DNA chip (Agilent Technologies, Santa Clara, CA, USA).

Bacterial 16S rRNA gene amplicons were submitted to New Zealand Genomics Limited for library preparation using a dualindexing approach with Nextera technology and sequencing ( 2 x 300 bp, paired-end) on the Illumina MiSeq. Metagenomic samples were submitted to New Zealand Genomics Limited for Thruplex DNA library preparation and sequencing ( 2 x 125 bp, paired-end) on one lane of the Illumina HiSeq.

\section{Data analyses}

\section{Bacterial 16S rRNA gene sequence analysis}

Bioinformatic processing of amplicon sequencing data involved a combination of USEARCH (version 7.0.1090, 64-bit built for Linux) and QIIME (version 1.8) ${ }^{(1,2)}$. Briefly, reads less than 200 bp after merging were removed from the dataset. USEARCH was used to cluster reads into de novo operational taxonomic units (OTUs) at $97 \%$ sequence similarity, singleton OTUs were removed, and taxonomy was assigned in QIIME using RDP v2.2 and SILVA $v 111$ as a reference ${ }^{(3,4)}$. Sequences that aligned to the human mitochondrial genome using BLAST (https://blast.ncbi. nlm.nih.gov/Blast.cgi) were removed from the dataset. Samples were rarefied to 1,678 sequences, and rarefied tables were used for all downstream analyses ${ }^{(5)}$. Alpha diversity measures Chao1, Shannon, Simpson and observed species (OTUs) diversity indices, and a Bray-Curtis dissimilarity matrix were assessed and generated using QIIME.

\section{Metagenomic sequencing analysis}

Raw reads were quality filtered using trimmomatic v 0.33 with default settings ${ }^{\left({ }^{6}\right)}$. To remove contaminating human DNA, the human reference genome GRCh38 was downloaded from the NCBI Genome database and quality-filtered reads aligned to the reference using bwa ${ }^{(7)}$. Reads that aligned to the human genome were removed, and the remaining sequences from each sample were assigned taxonomy using Kraken v0.10.5-beta and a custom-built database compiled with all archaeal, fungal, bacterial, viral and protozoan genomes available on $\mathrm{NCBI}$ as of September 13, $2016^{(8)}$. The Bracken bioinformatics program was used to calculate abundances from Kraken-assigned taxonomy at the phylum, family, and species levels, and these data were used for all downstream analyses ${ }^{(9)}$.

Efficacy of enrichment techniques was assessed as the proportion of microbial classified sequencing reads, once humanassigned reads were removed, to the total number of reads prior to classification. The mean value and standard deviation of classified sequences for each method were calculated and visualized as strip plots using the program ggplot2 in $\mathrm{R}$ version $3.2 .5^{(10,11)}$. Coefficient of variation, tests for normality, and pairwise tests were calculated using the native 'stats' package in $\mathrm{R}$ for each method to give an indication of the reproducibility, distribution, 
and quantifiable differences between methods, respectively (11). Relative abundances of the 22 most abundant microbial families within the amplicon and metagenomics datasets were calculated and visualized in R. Beta diversity metrics for metagenomics data were calculated using the species-level Bracken abundance taxon table using a Bray-Curtis dissimilarity matrix generated with the 'vegdist' function in the vegan package ${ }^{(12)}$. Non-metric multidimensional scaling (nMDS) plots for both amplicon and metagenomics datasets were generated as previously described (13). Comparisons of total microbial, and bacterial only, diversity at family level, as assessed by the amplicon and metagenomics approaches, were calculated in QIIME v1.9 using Spearman correlations and all other default settings in the compare_taxa_ summaries.py command.

\section{Population genome assembly and binning}

After quality filtering and removal of human DNA from the HiSeq dataset, high-quality sequences from all samples were pooled and assembled using SPAdes v3.7.1 ${ }^{(14)}$. Reads from each sample were separately mapped to the resulting assembly using BamM v1.7.3 (https://github.com/Ecogenomics/BamM) and differential coverage binning performed using GroopM v0.3.4 (15). Completeness and contamination of each population genome bin were assessed using the presence or absence of $120 \mathrm{sin}$ gle copy marker genes using CheckM v1.0.7 ${ }^{(16)}$. Several bins were reported, including one bin that identified as a member of the genus Staphylococcus. However, this genome reported only $45.88 \%$ completeness with $1.30 \%$ contamination, and was not pursued for reconstruction. A single near-complete genome (97.35\% complete) with no contamination was reconstructed. This population bin, identified as the bacterium Propionibacterium acnes, was examined for contigs with abnormal coverage or composition profile using RefineM v0.0.13 (https://github.com/dparks1134/refinem), then gaps filled and the refined genome bin assembled into scaffolds using FinishM (https://github.com/wwood/finishm).

\section{Analysis of the Propionibacterium acnes genome}

Taxonomic identification of the refined genome bin was performed against a reference set of 14,256 high-quality bacterial genomes downloaded from the Genome Taxonomy Database (http://gtdb.ecogenomic.org/) using a concatenated protein sequence obtained from 120 marker genes ${ }^{(17)}$. Phylogenetic inference was performed using FastTree v2.1.9 ${ }^{(18)}$ with the $W A G+\Gamma$ model of amino acid evolution and 100 bootstrap iterations to assess node support. A high-resolution tree for specieslevel identification and publication purposes was constructed from a subset of 44 reference genomes, consisting of closely related and outgroup genomes from different phyla, using RAxML v8.1.4 ${ }^{(19)}$ under the same evolution model and bootstrap criteria, for display purposes.
Gene prediction, annotation, and metabolic reconstruction for the recovered $P$. acnes genome were carried out using Rapid Annotations using Subsystems Technology (RAST) online server and all default settings ${ }^{(20)}$. The RAST server was used to compare the recovered $P$. acnes genome to that of its closest phylogenetic neighbour, P. acnes strain KPA171202.

\section{Statistical analyses}

The similarity percentage (SIMPER) approach was used to identify microbial community similarities between groups of samples based on enrichment method for each type of sequencing data. The species-level metagenome taxa summary and the amplicon taxon-assigned OTU tables were square root-transformed and SIMPER analyses were conducted in PRIMER6 version 6.1.13 using Bray-Curtis similarities ${ }^{(21)}$. Permutational analysis of variance (PERMANOVA) was used to partition variation within the data due to inter-individual variation and enrichment method, and analysis of similarity (ANOSIM) was used to assess patterns in microbial community composition between methods for both amplicon and metagenomics datasets. Multivariate dispersion (MVDISP) was used to quantify relative multivariate variability between methods. PERMANOVA, ANOSIM, and MVDISP analyses were performed in PRIMER6 version 6.1.13 using Bray-Curtis dissimilarity matrices generated from each dataset ${ }^{(22)}$.

\section{References}

1. Edgar RC. UPARSE: highly accurate OTU sequences from microbial amplicon reads. Nat Methods. 2013;10(10):996-8.

2. Caporaso JG, Kuczynski J, Stombaugh J, Bittinger K, Bushman FD, Costello EK, et al. QIIME allows analysis of high-throughput community sequencing data. Nature. 2010;7(5):335-6.

3. Quast C, Pruesse E, Yilmaz P, Gerken J, Schweer T, Glo FO, et al. The SILVA ribosomal RNA gene database project : improved data processing and web-based tools. Nucleic Acids Res. 2013;41:590-6.

4. Wang Q, Garrity GM, Tiedje JM, Cole JR. Naïve Bayesian classifier for rapid assignment of rRNA sequences into the new bacterial taxonomy. Appl Environ Microbiol. 2007;73(16):5261-7.

5. Johnson M, Zaretskaya I, Raytselis Y, Merezhuk Y, McGinnis S, Madden TL. NCBI BLAST: a better web interface. Nucleic Acids Res. 2008;36:5-9.

6. Bolger AM, Lohse M, Usadel B. Trimmomatic: A flexible trimmer for Illumina sequence data. Bioinformatics. 2014;30:2114.

7. Li H, Durbin R. Fast and accurate short read alignment with BurrowsWheeler transform. Bioinformatics. 2009;25(14):1754-60.

8. Wood DE, Salzberg SL. Kraken : ultrafast metagenomic sequence classification using exact alignments. Genome Biol. 2014;15(3).

9. Lu J, Breitwieser FP, Thielen P, Salzberg SL. Bracken: Estimating species abundance in metagenomics data. bioRxiv. 2016;1-14.

10. Wickham H. ggplot2: Elegant Graphics for Data Analysis. SpringerVerglad, New York; 2009. Available from: http://ggplot2.org

11. R Development Core Team. R: A Language and Environment for Statistical Computing. Vienna, Austria; 2012. Available from: http:// 
wWw.r-project.org/

12. Oksanen AJ, Blanchet FG, Kindt R, Legen- P, Minchin PR, Hara RBO, et al. Vegan: Community ecology package. R Package Version 2.0.10. 2011.

13. Wagner Mackenzie B, Waite DW, Hoggard M, Douglas RG, Taylor MW, Biswas K. Bacterial community collapse: A meta-analysis of the sinonasal microbiota in chronic rhinosinusitis. Environ Microbiol. 2016;19:381-92.

14. Bankevich A, Nurk S, Antipov D, Gurevich AA, Dvorkin M, Kulikov AS, et al. SPAdes: A new genome assembly algorithm and its applications to single-cell sequencing. J Comput Biol. 2012;19(5):455-77.

15. Imelfort M, Parks D, Woodcroft BJ, Dennis P, Hugenholtz P, Tyson GW. GroopM: An automated tool for the recovery of population genomes from related metagenomes. PeerJ Prepr. 2014;2:e409v1.

16. Parks DH, Imelfort M, Skennerton CT, Hugenholtz P, Tyson GW. CheckM: assessing the quality of microbial genomes recovered from. Genome Res. 2015;1:1-31.
17. Ormerod KL, Wood DLA, Lachner N, Gellatly SL, Daly JN, Parsons JD, et al. Genomic characterization of the uncultured Bacteroidales family S24-7 inhabiting the guts of homeothermic animals. Microbiome. 2016;4:1-17.

18. Price MN, Dehal PS, Arkin AP. FastTree: computing large minimum evolution trees with profiles instead of a distance matrix. Mol Biol Evol. 2009;26(7):1641-50.

19. Stamatakis A. RAXML version 8: A tool for phylogenetic analysis and post-analysis of large phylogenies. Bioinformatics. 2014;30(9):1312-3.

20. Aziz RK, Bartels D, Best A, DeJongh M, Disz T, Edwards RA, et al. The RAST Server: Rapid annotations using subsystems technology. BMC Genomics. 2008:9:1-15.

21. Clarke KR. Non-parametric multivariate analyses of changes in community structure. Aust J Ecol. 1993;18:117-43.

22. Anderson MJ, Gorley RN, Clarke KR. PERMANOVA+ for PRIMER: Guide to Software and Statistical Methods. Plymouth, U.K.: PRIMER-E Ltd; 2008. 


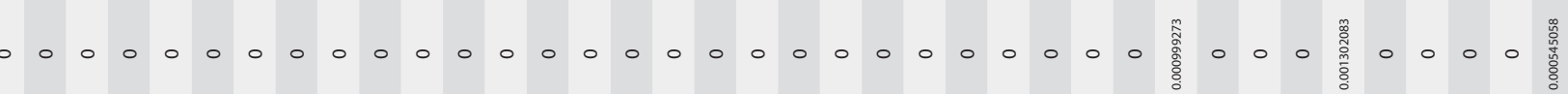

$\stackrel{m}{\sum_{n}}$

勇

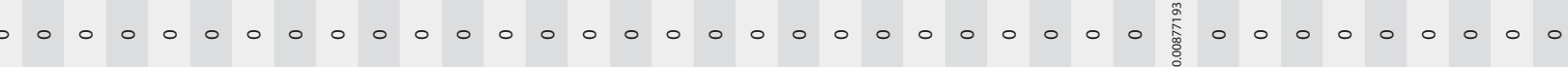

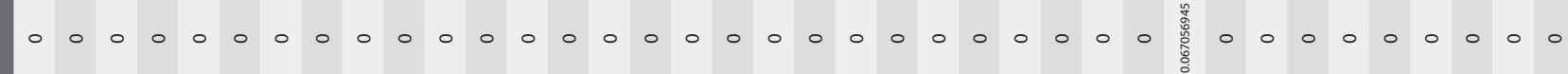

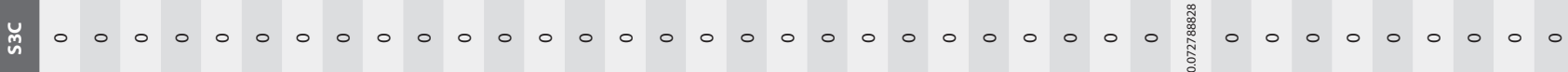

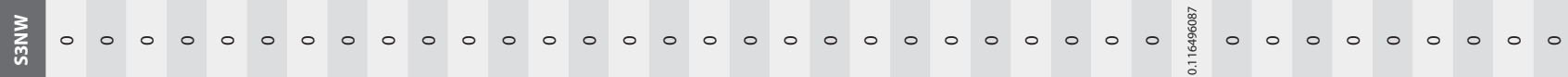

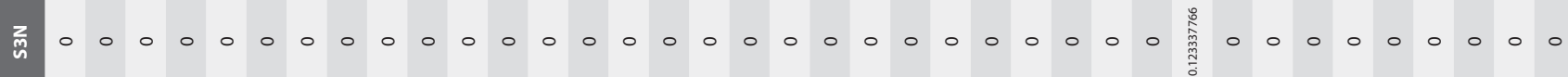
尊

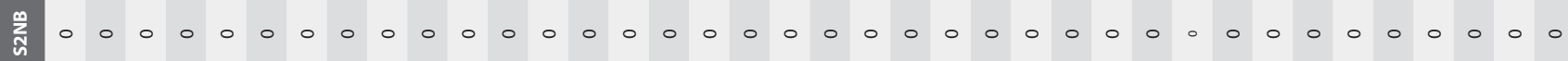

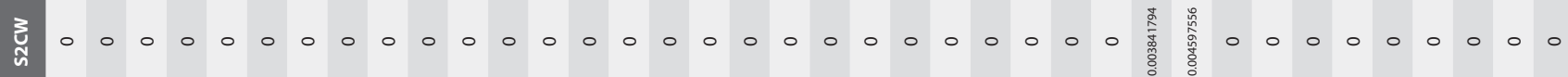

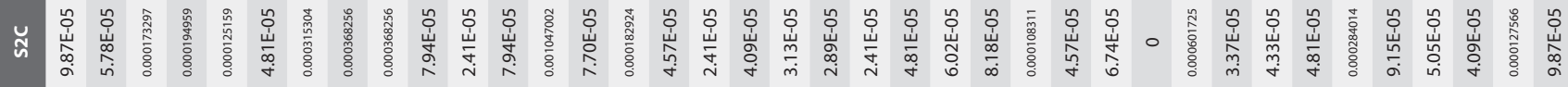

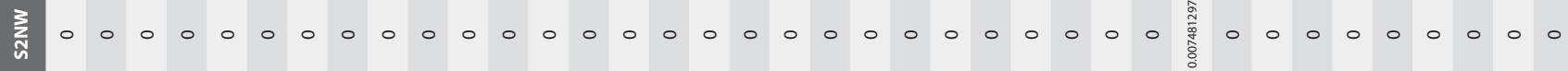

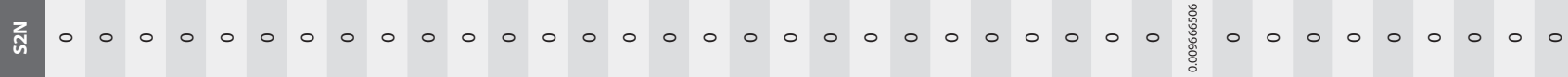

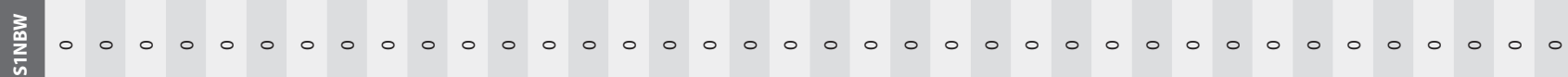

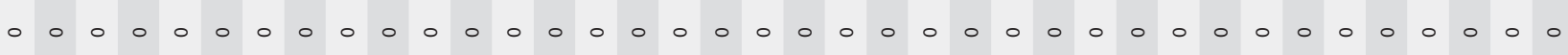

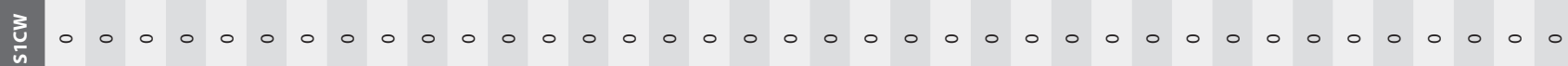

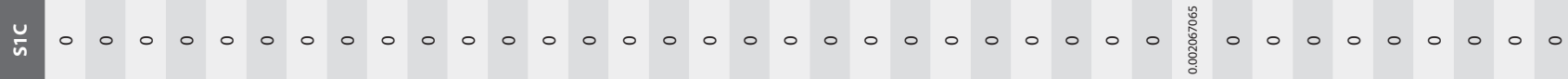

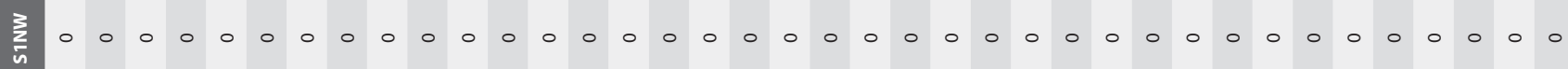

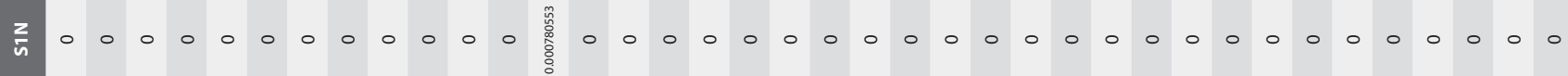

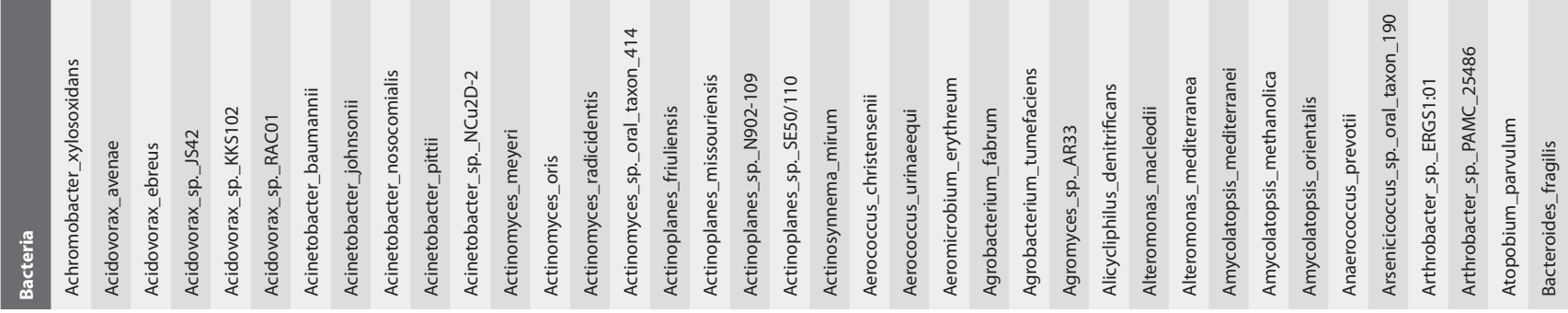




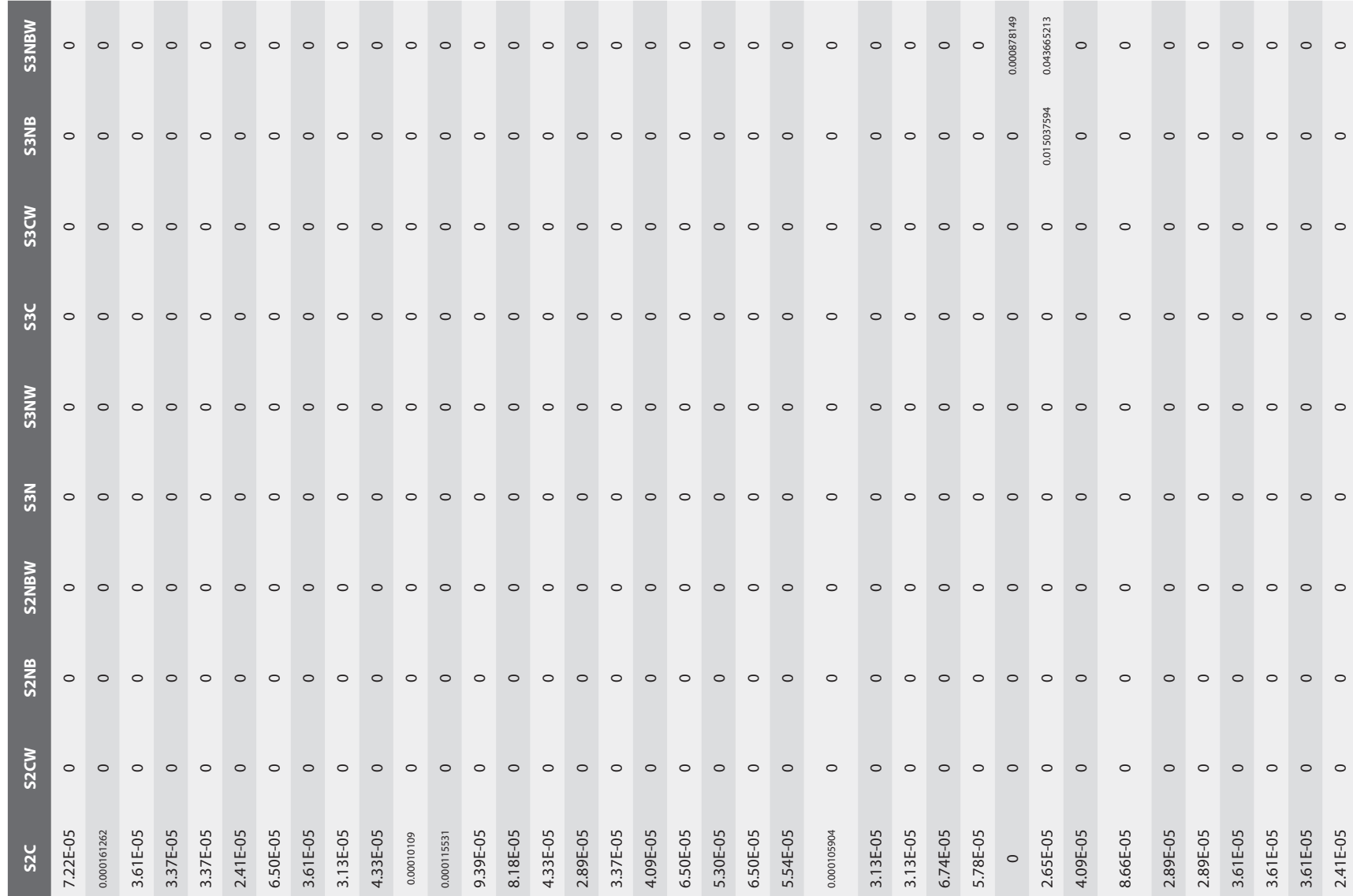

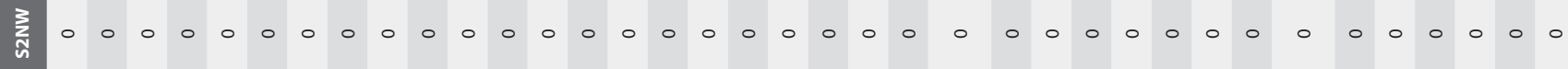

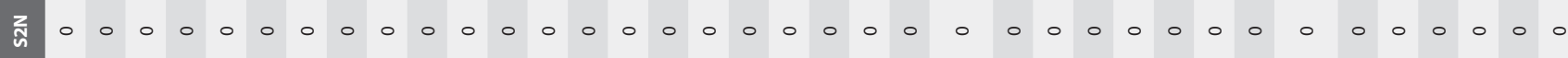

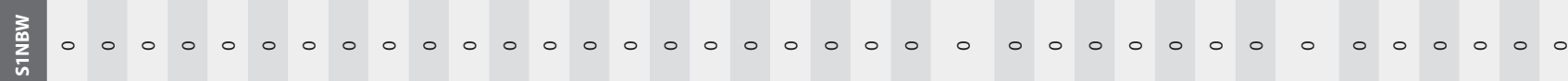

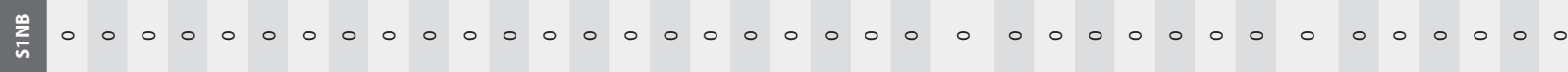

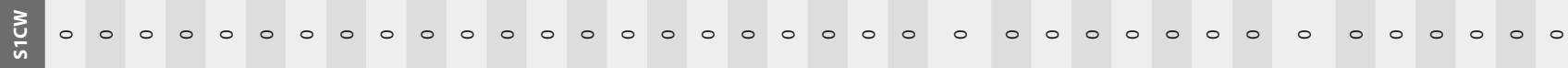

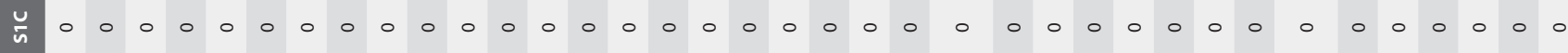

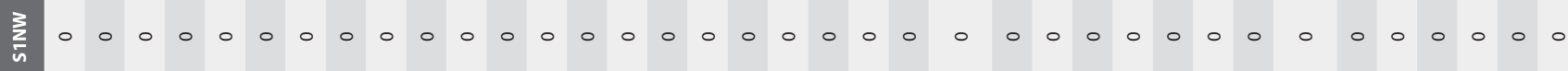

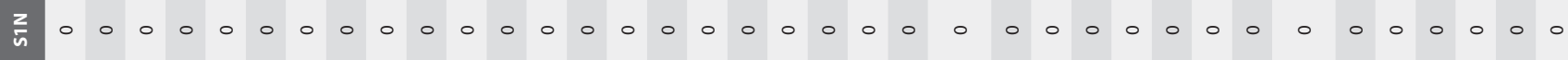

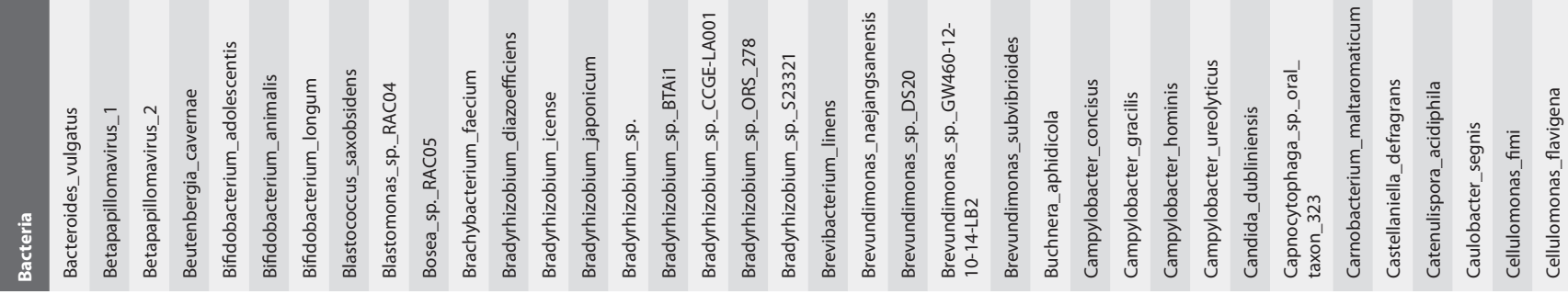




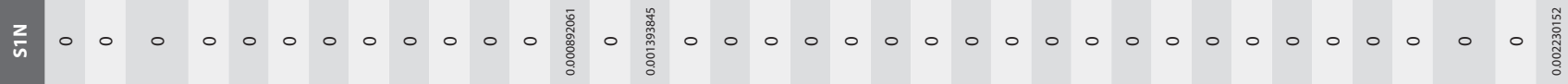

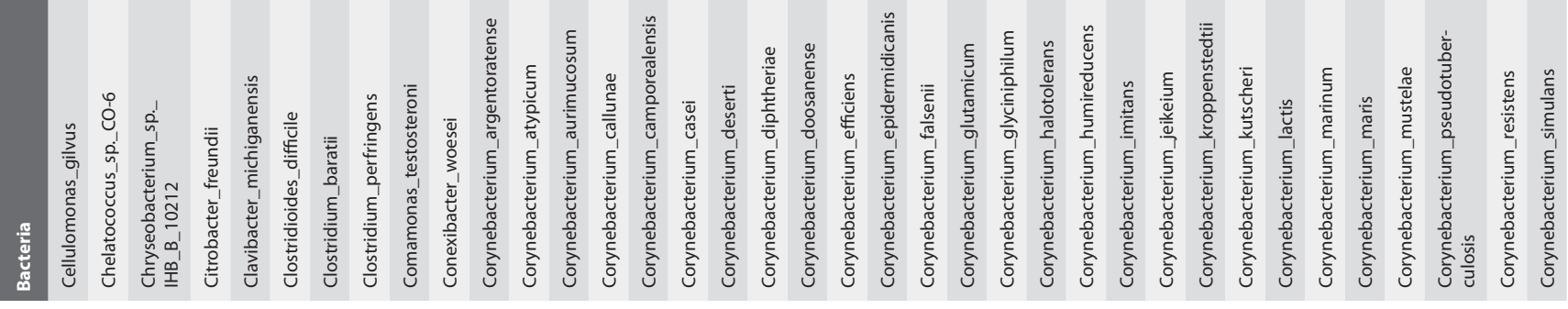




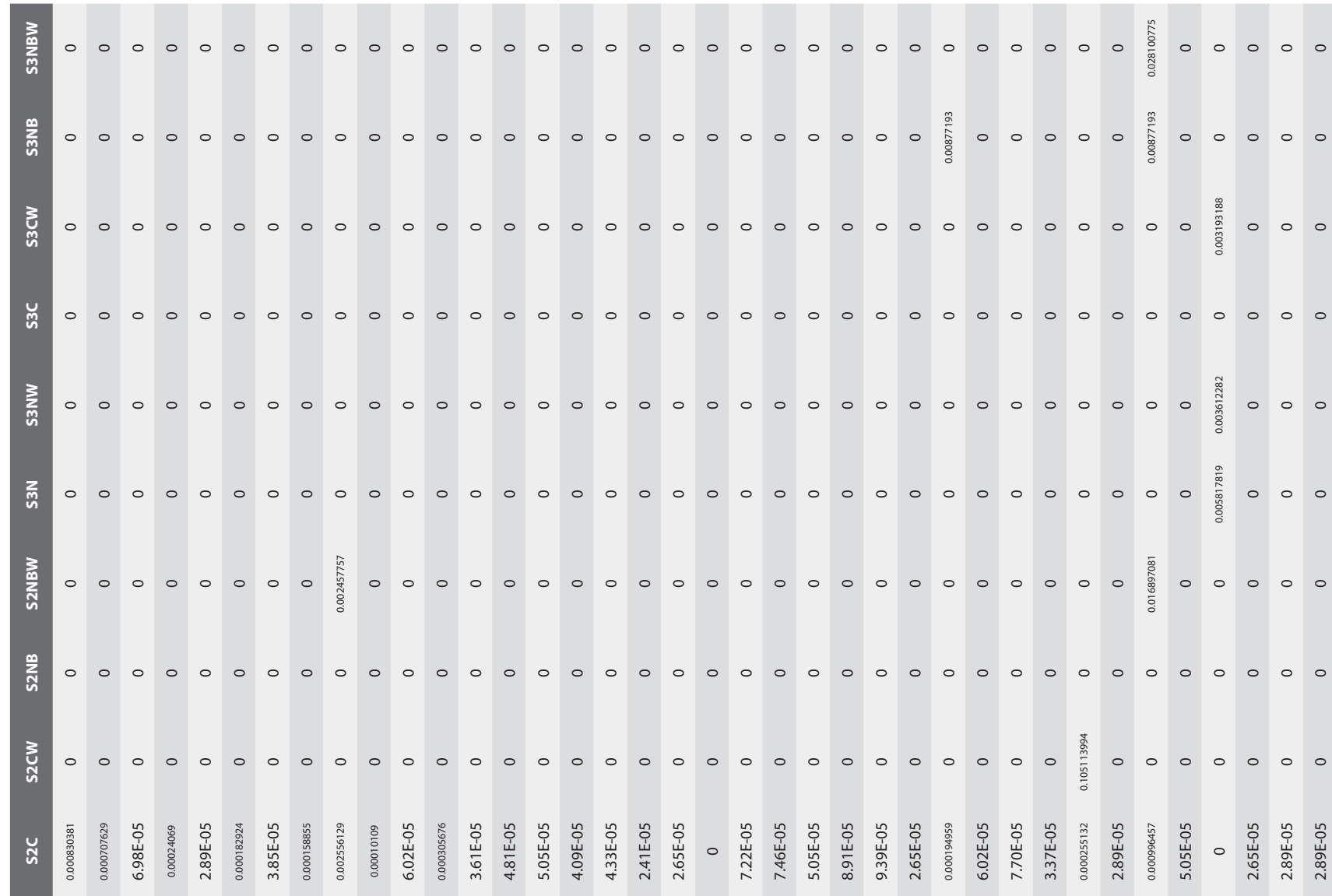

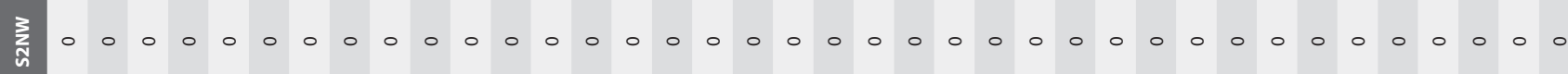

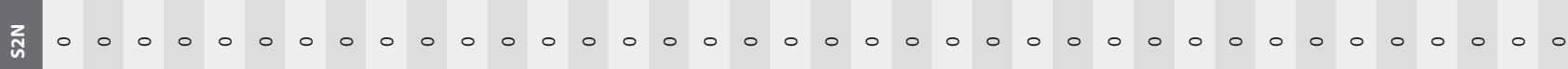

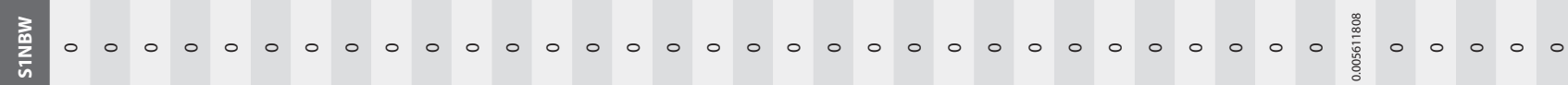

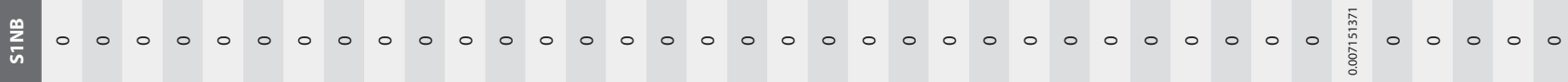

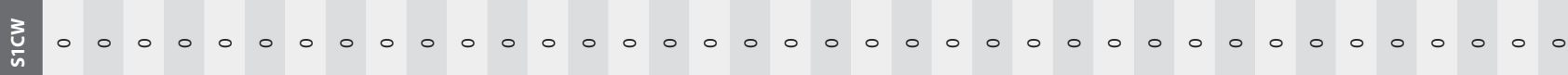

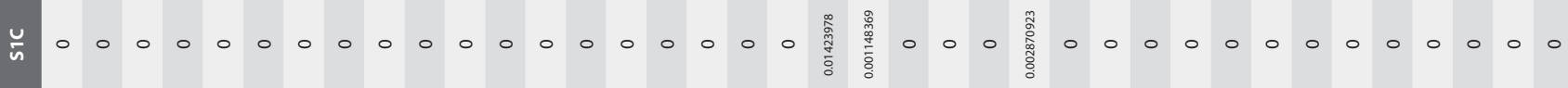

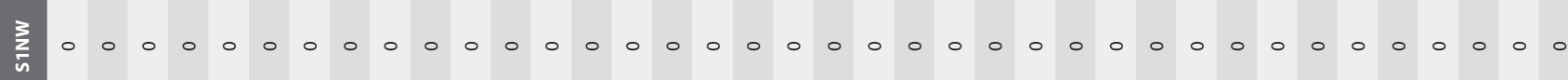

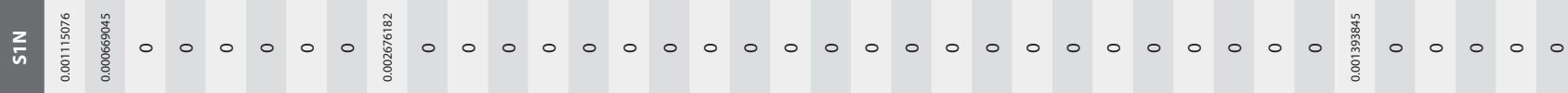

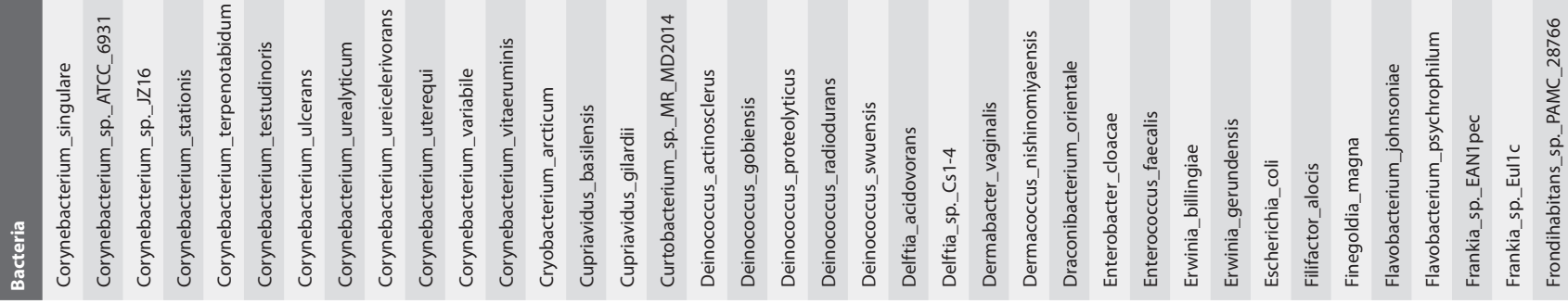




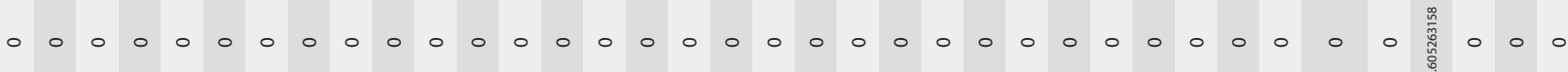
3
3

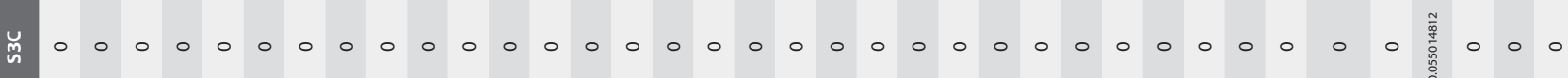

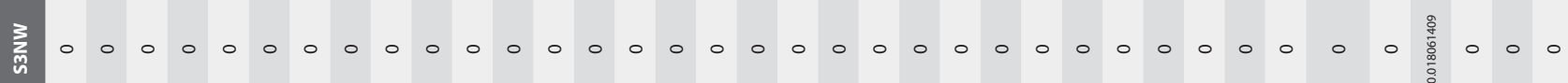

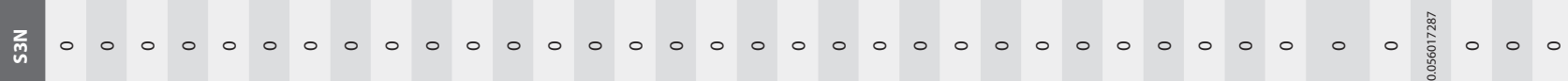

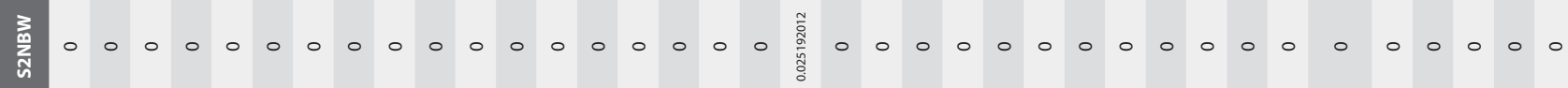
m.

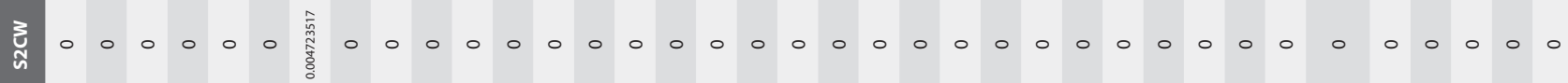

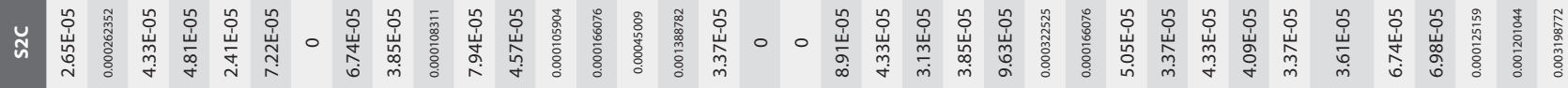
0.0000000000000000000000000000000000 0.00000000000000000000000000000000 0.0000000000000000000000000000000000

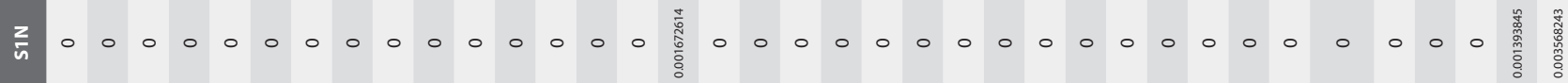

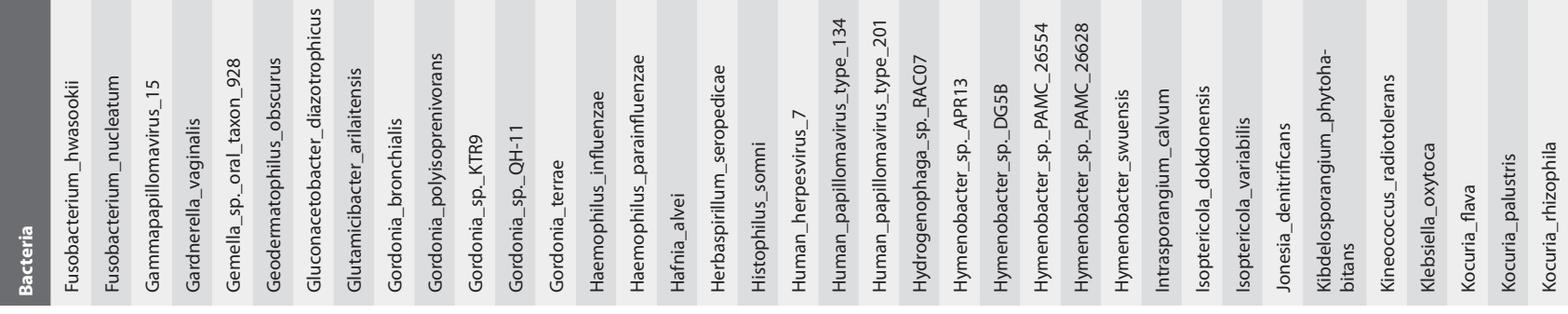




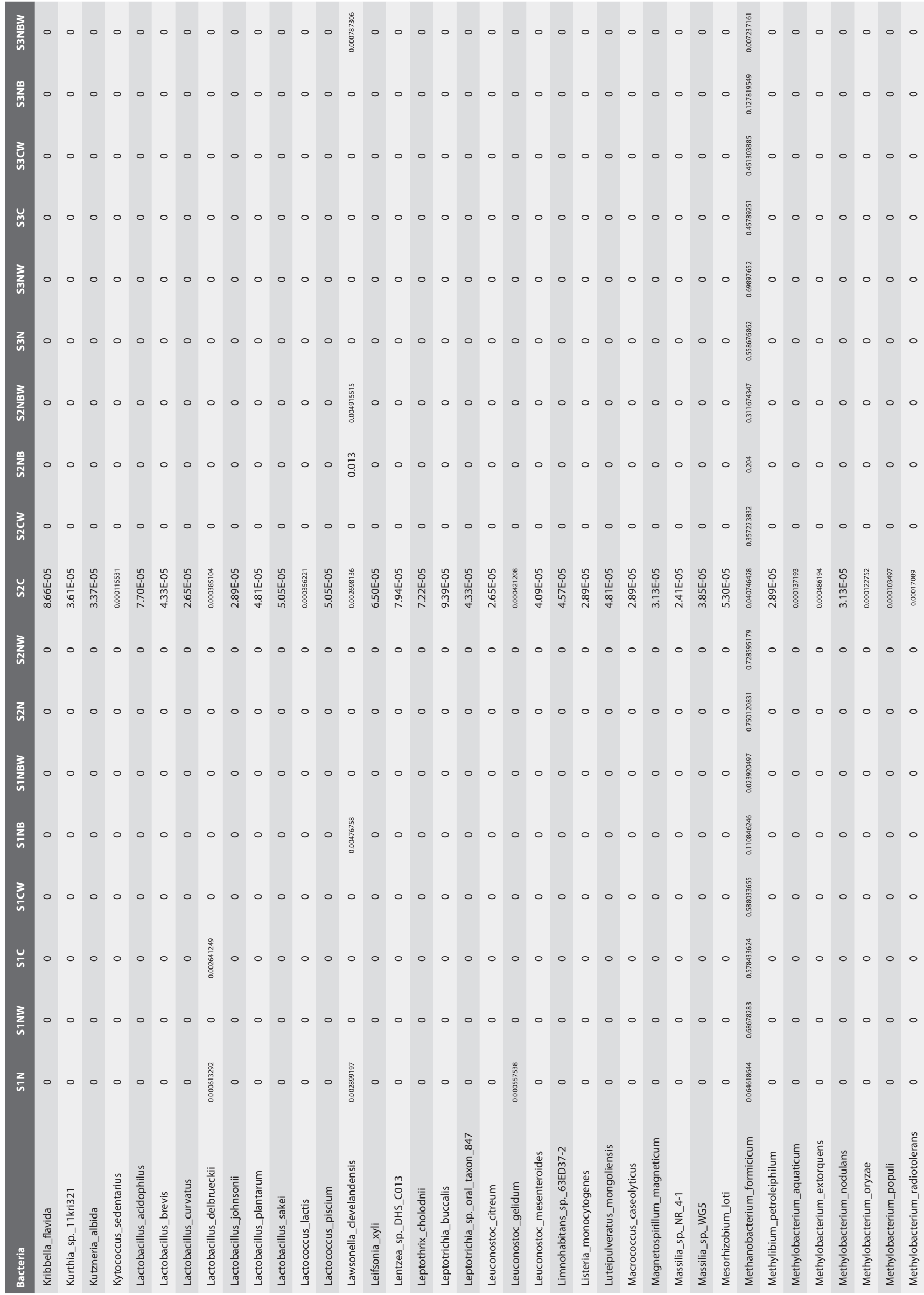


慈。

总。

总。

un

竓。

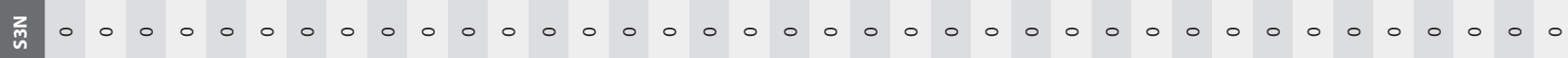

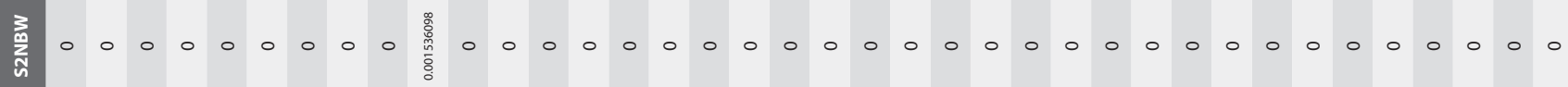

岕

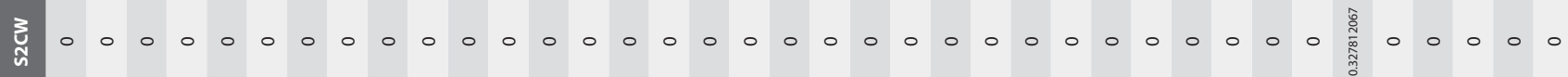

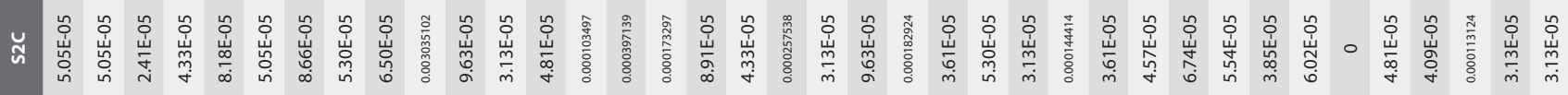

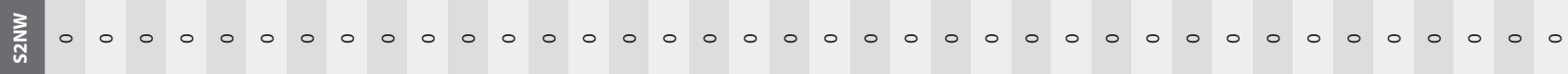

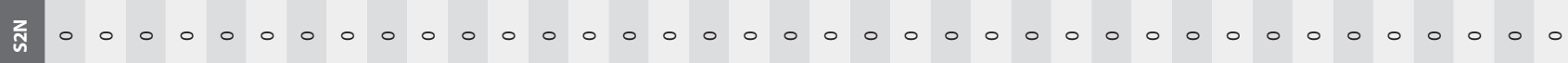

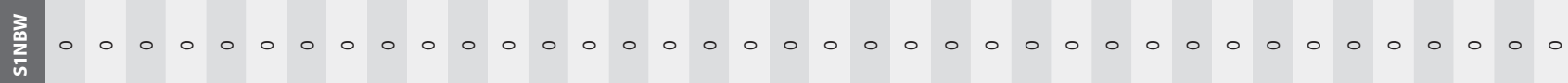

$\frac{m}{n}$

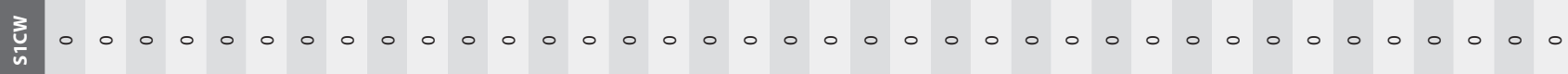

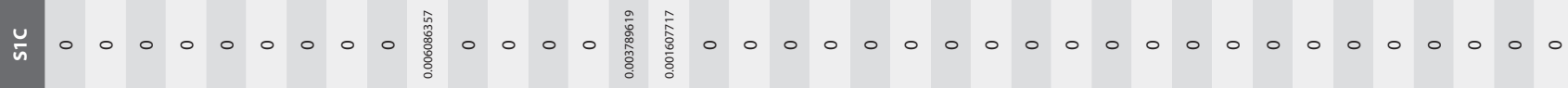

$\frac{n}{n}$

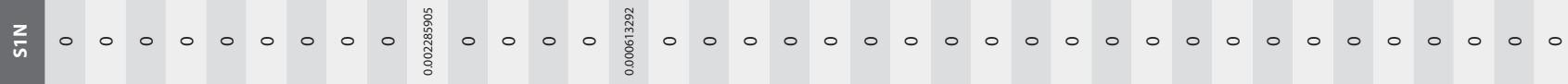

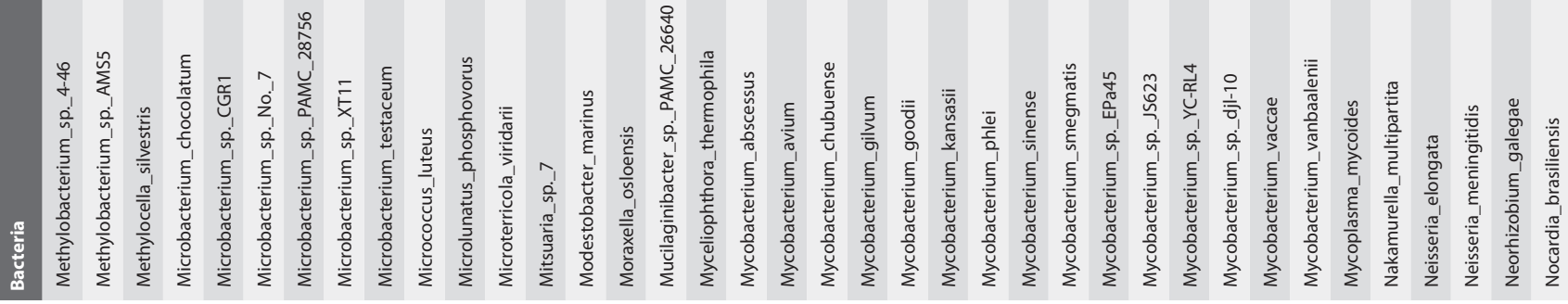




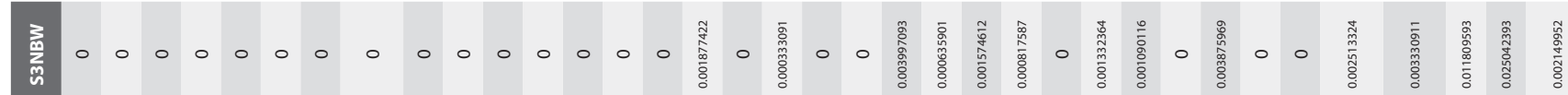

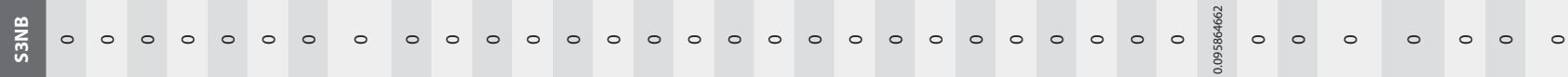

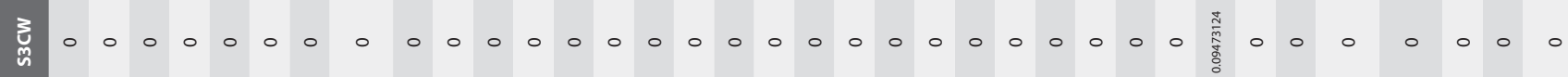

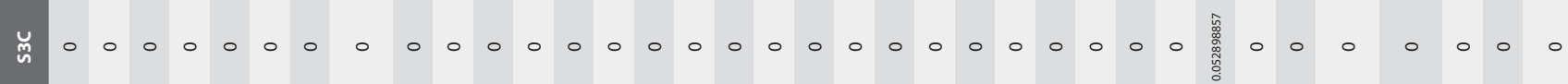

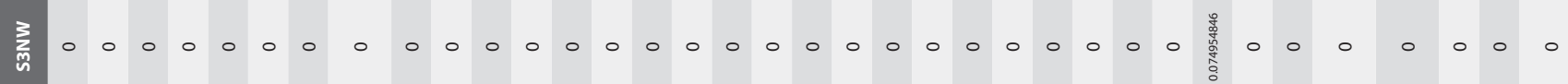

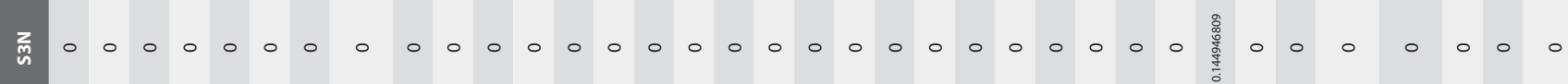

眷

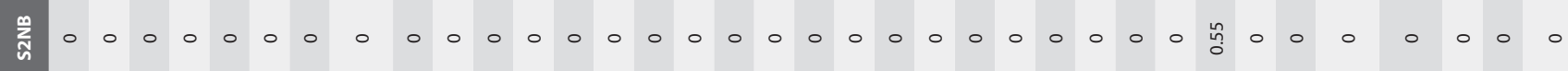

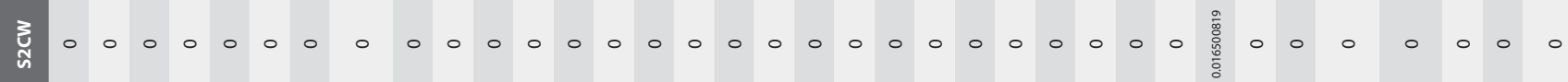

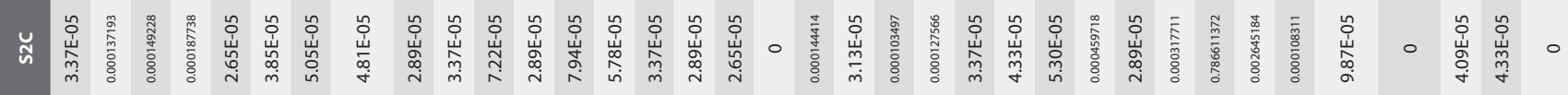

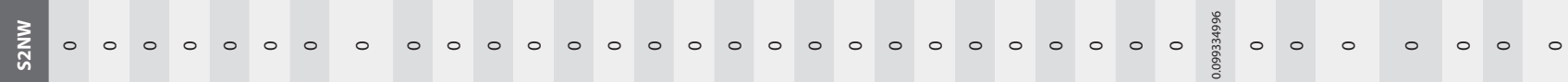

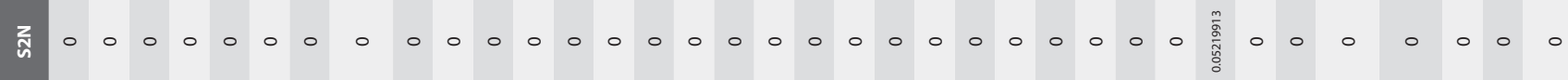

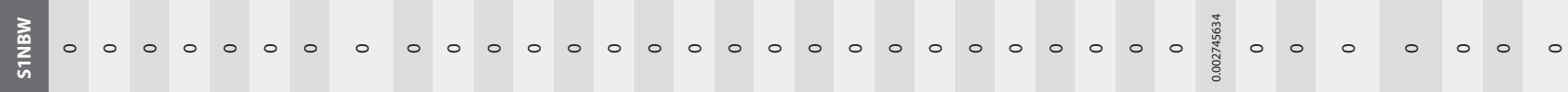

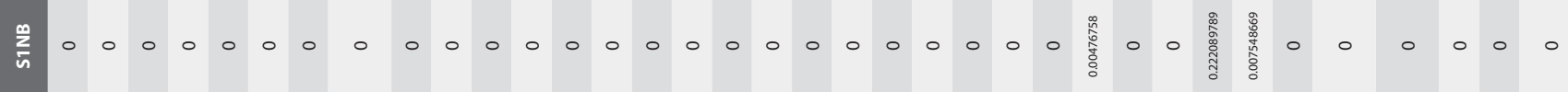

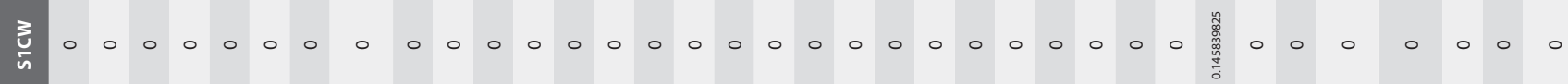

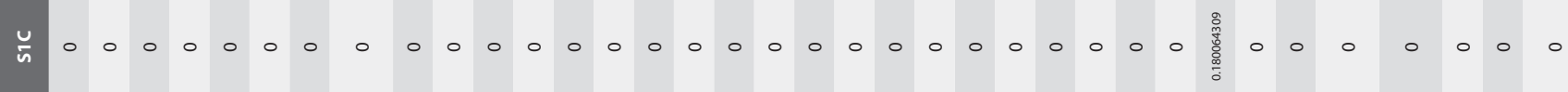

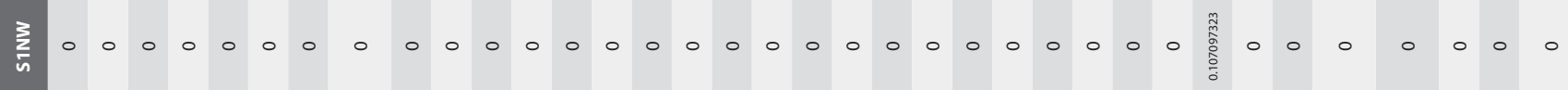

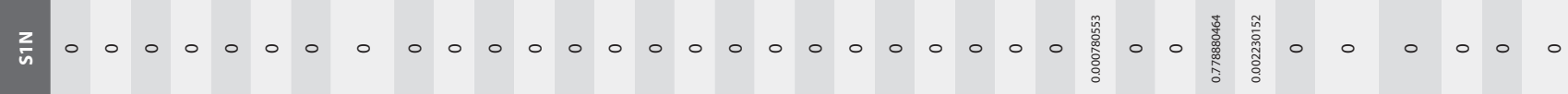

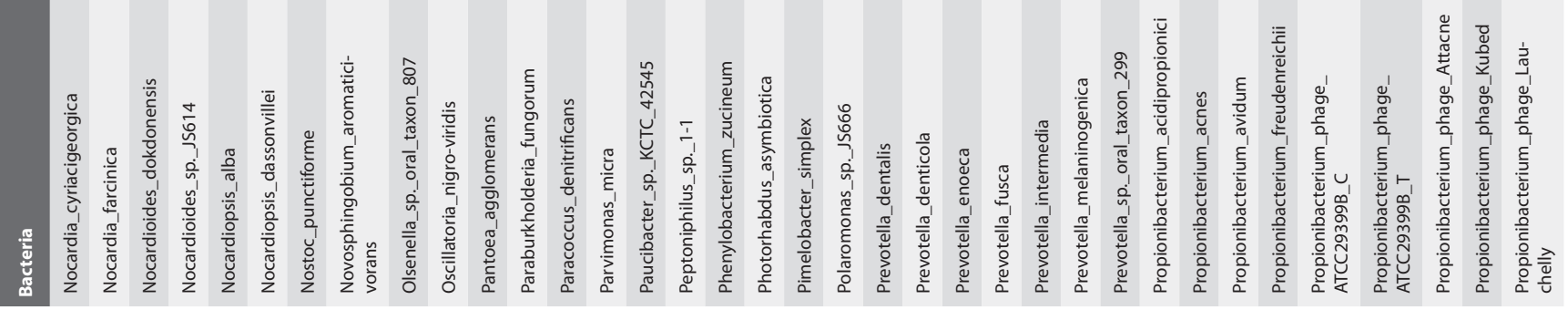




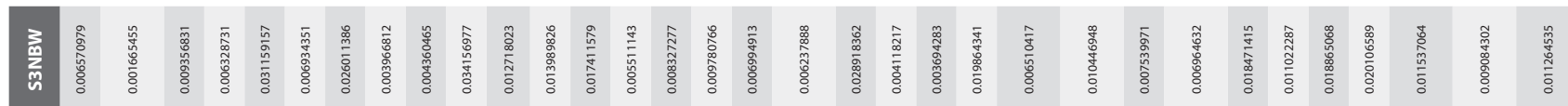

总。

总。

$\breve{m}$

站。

z

总。

并。

갱

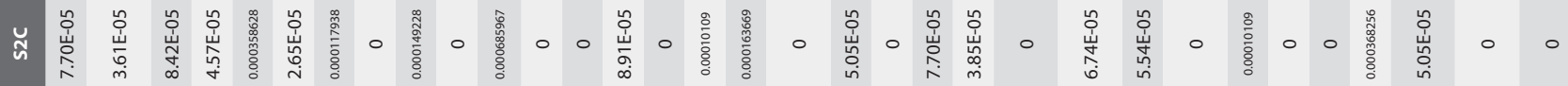

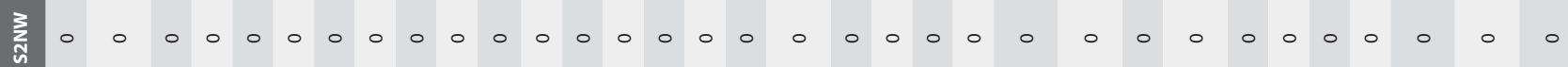

증

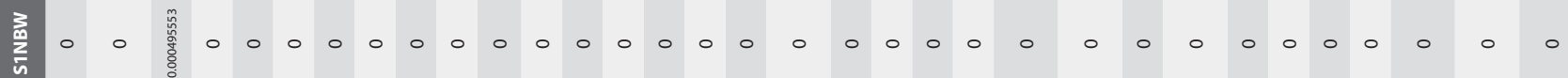

孞

$\frac{3}{n} \circ$

$\frac{u}{n} \circ$

$\sum_{n}^{3}$

z

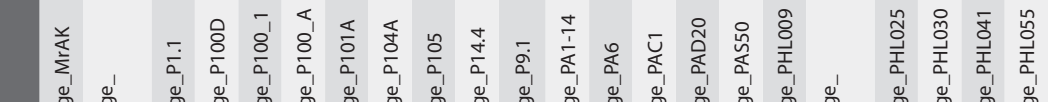

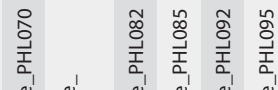

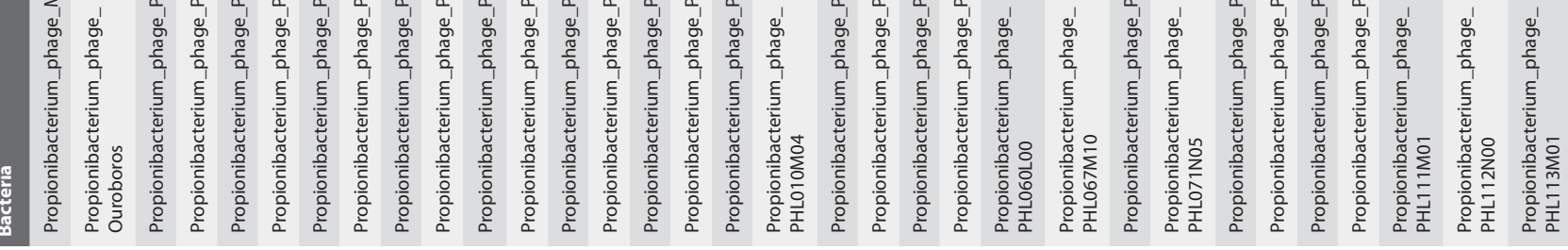


\|\|$\| \ldots \ldots \ldots$

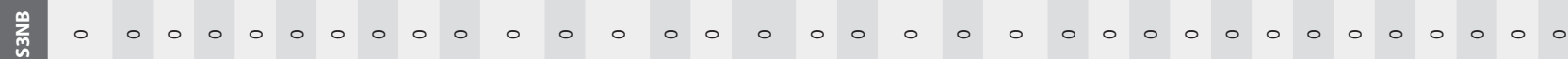

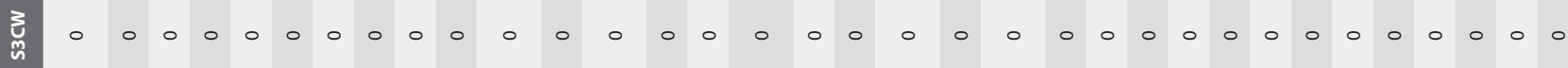
$\underline{W}$

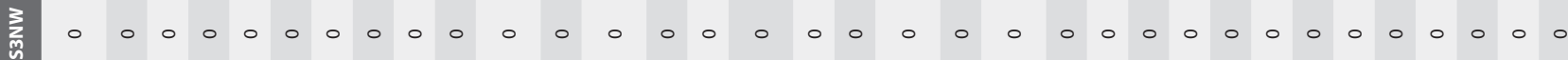

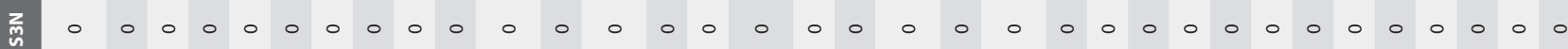

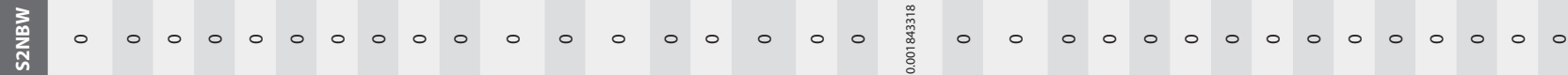
岕

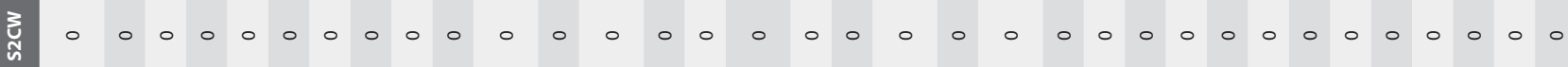

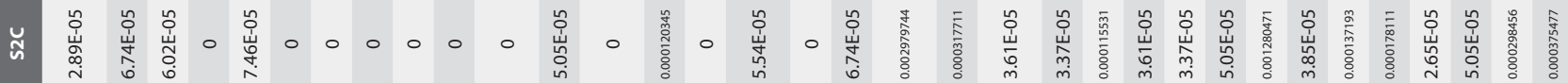
宓

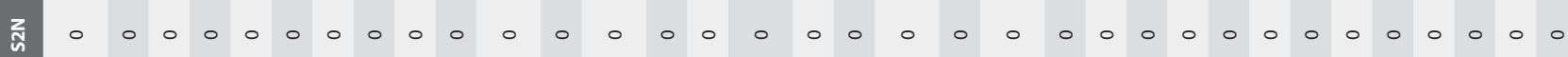

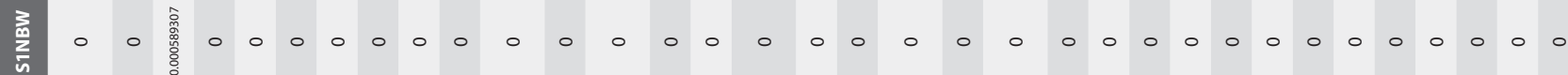

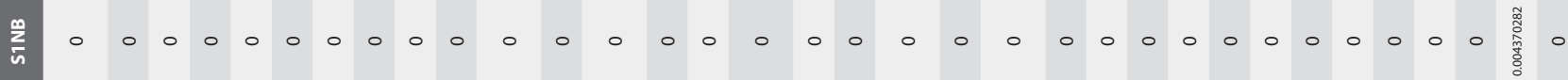
$\frac{3}{n}$

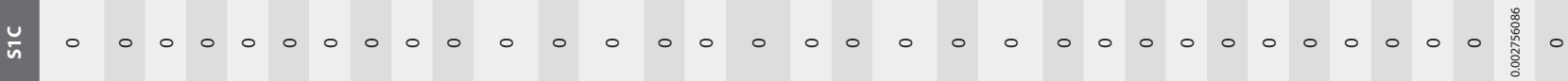
$\frac{3}{n}$

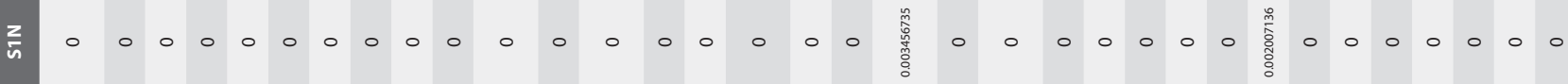

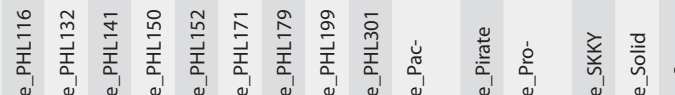

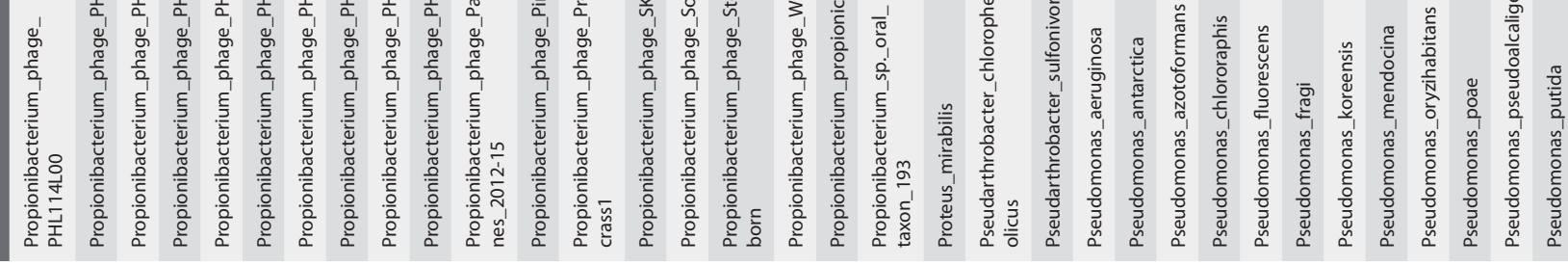


孳。

$\sum_{\text {品。 }}^{\infty}$

总。

un

竞。

z

蔏

离

్ㅐ

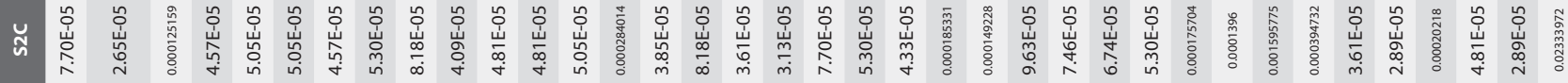

\begin{tabular}{lllllllllllllllllllllllllllllllllllllll}
$\sum_{\text {幺 }}^{3}$ & 0 & 0 & 0 & 0 & 0 & 0 & 0 & 0 & 0 & 0 & 0 & 0 & 0 & 0 & 0 & 0 & 0 & 0 & 0 & 0 & 0 & 0 & 0 & 0 & 0 & 0 & 0 & 0 & 0 & 0 & 0 & 0 & 0 & 0 & 0 & 0 & $\frac{g_{0}^{0}}{0}$ \\
\hline
\end{tabular}

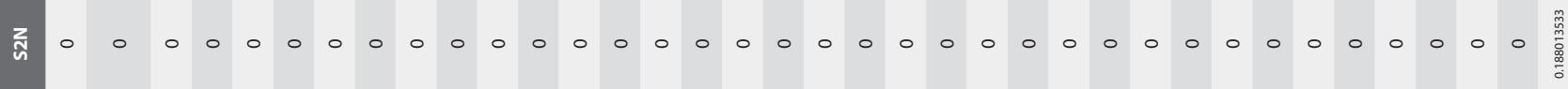

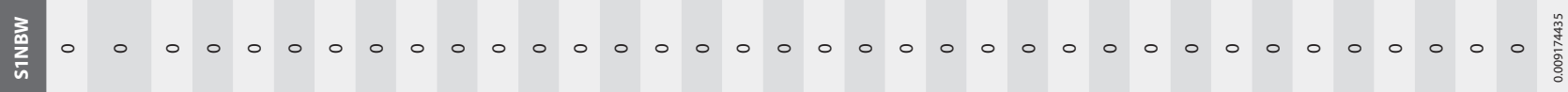

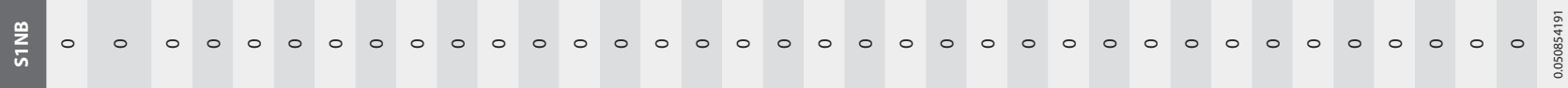

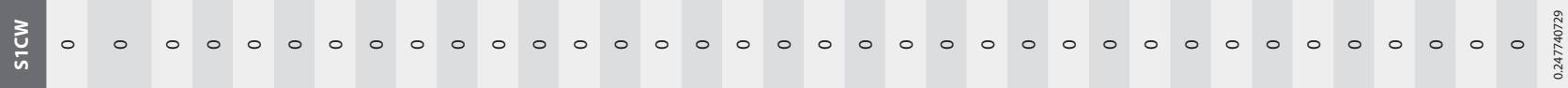

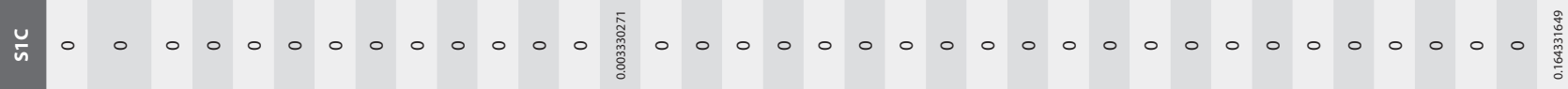

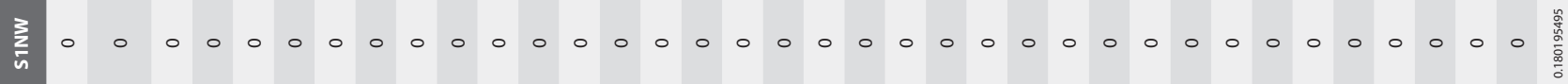

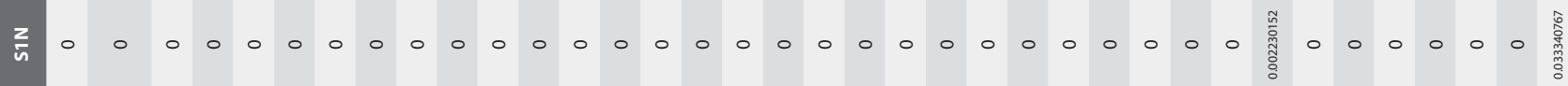

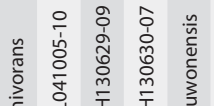

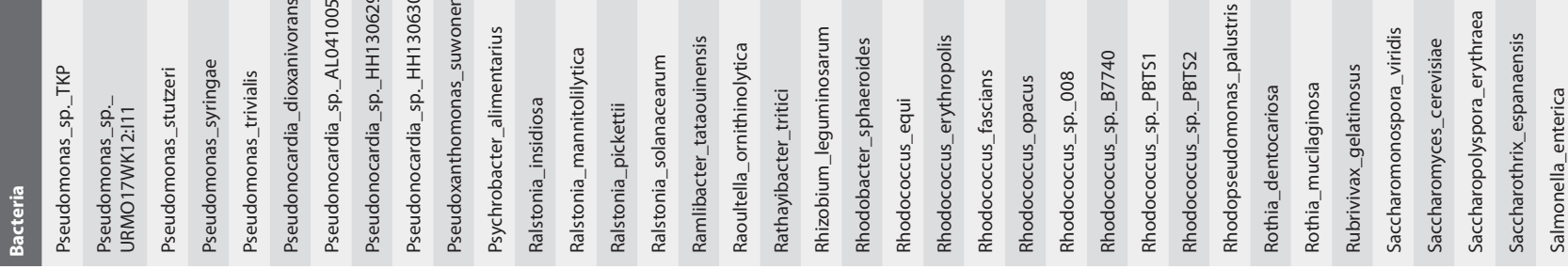




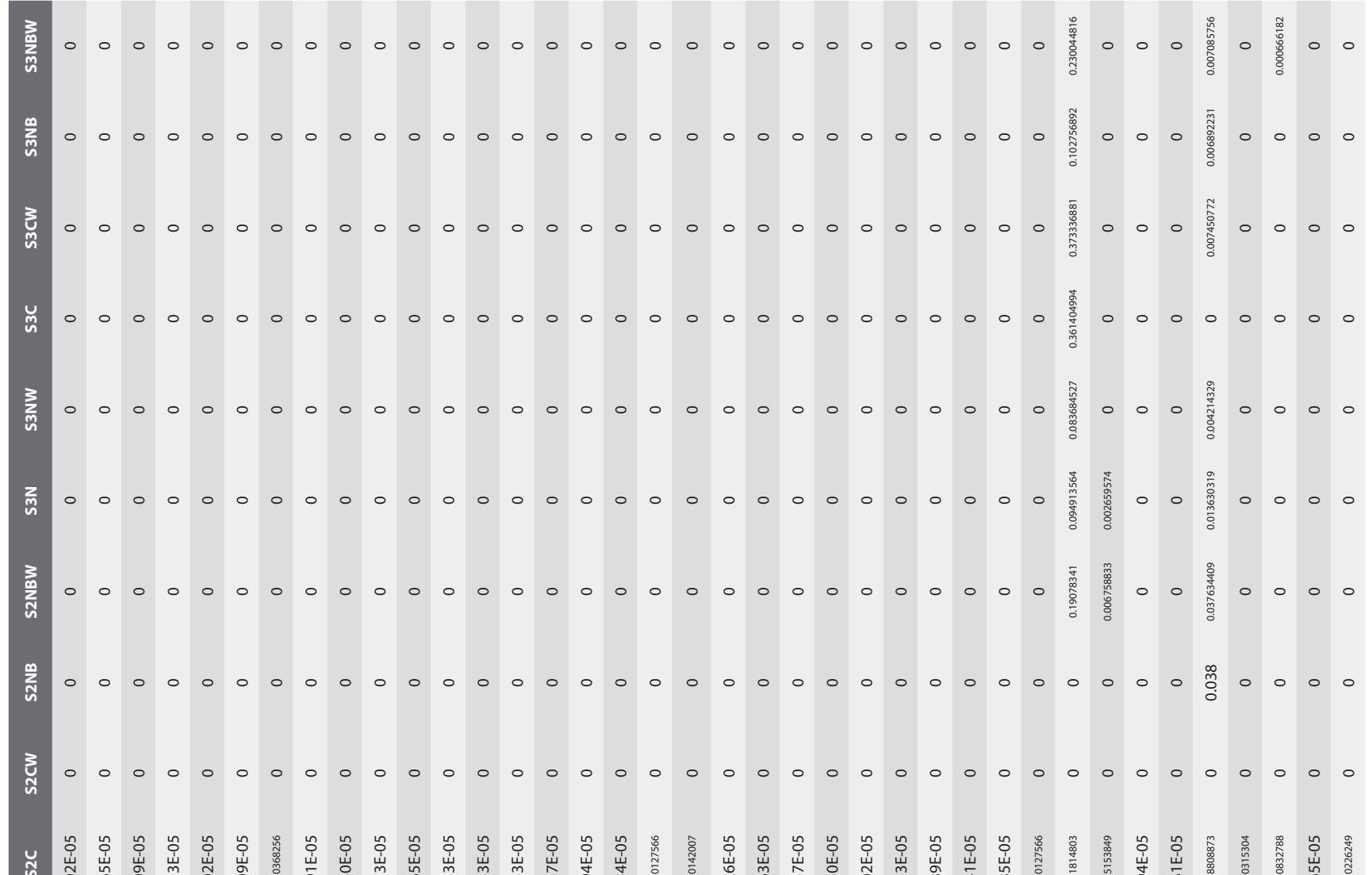

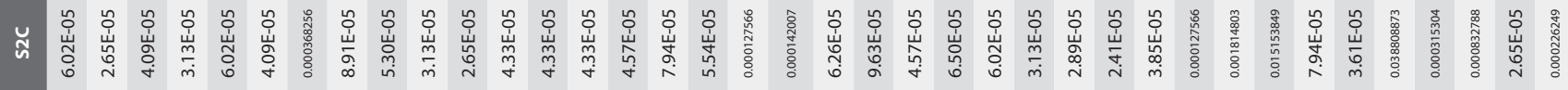

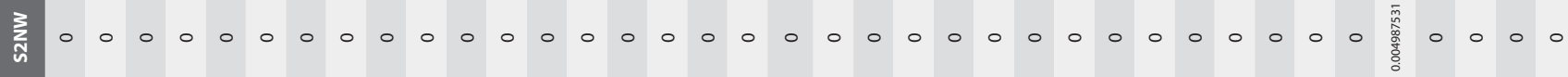

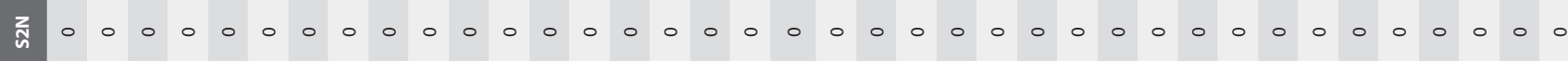

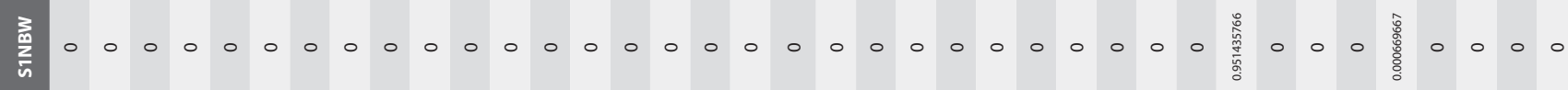

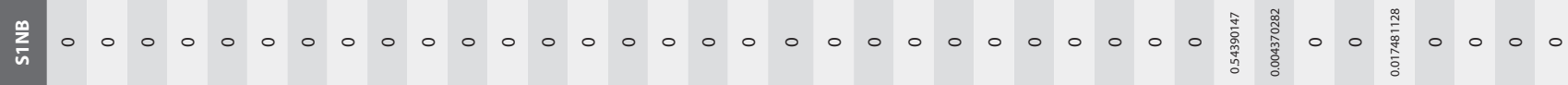

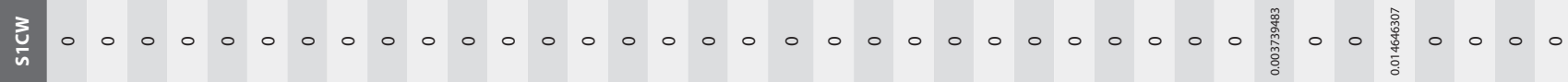

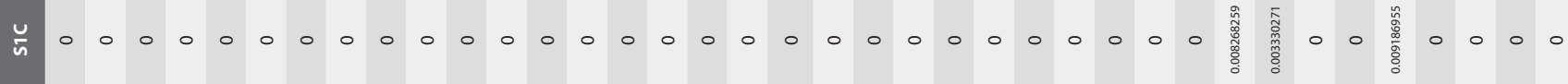

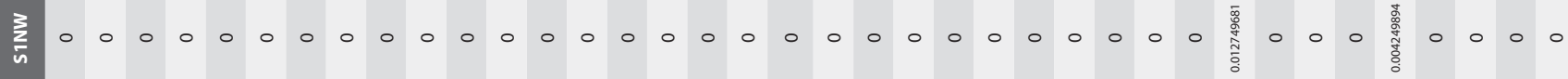

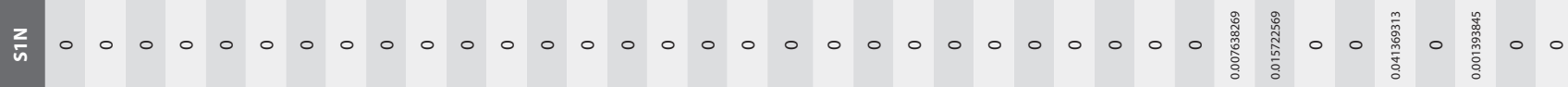

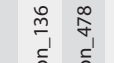

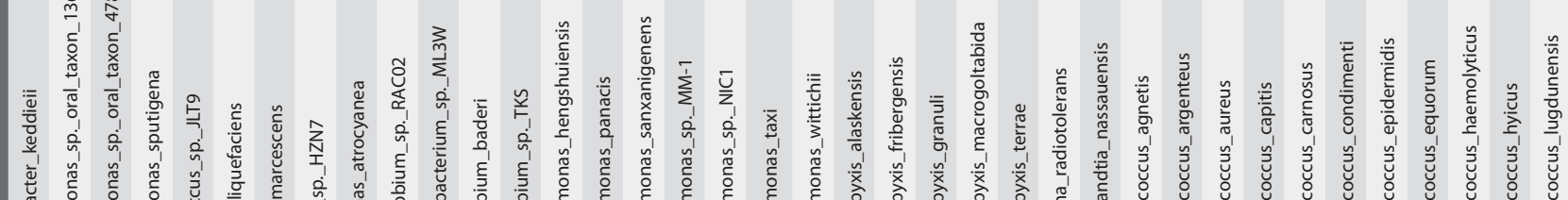

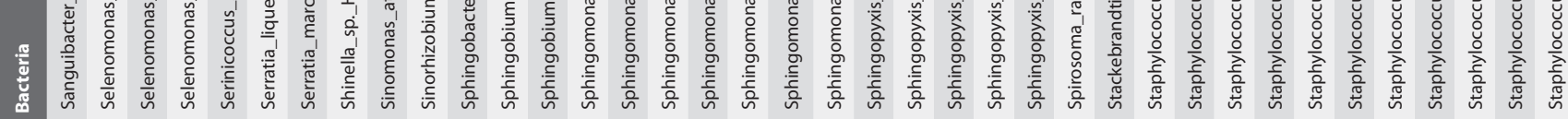




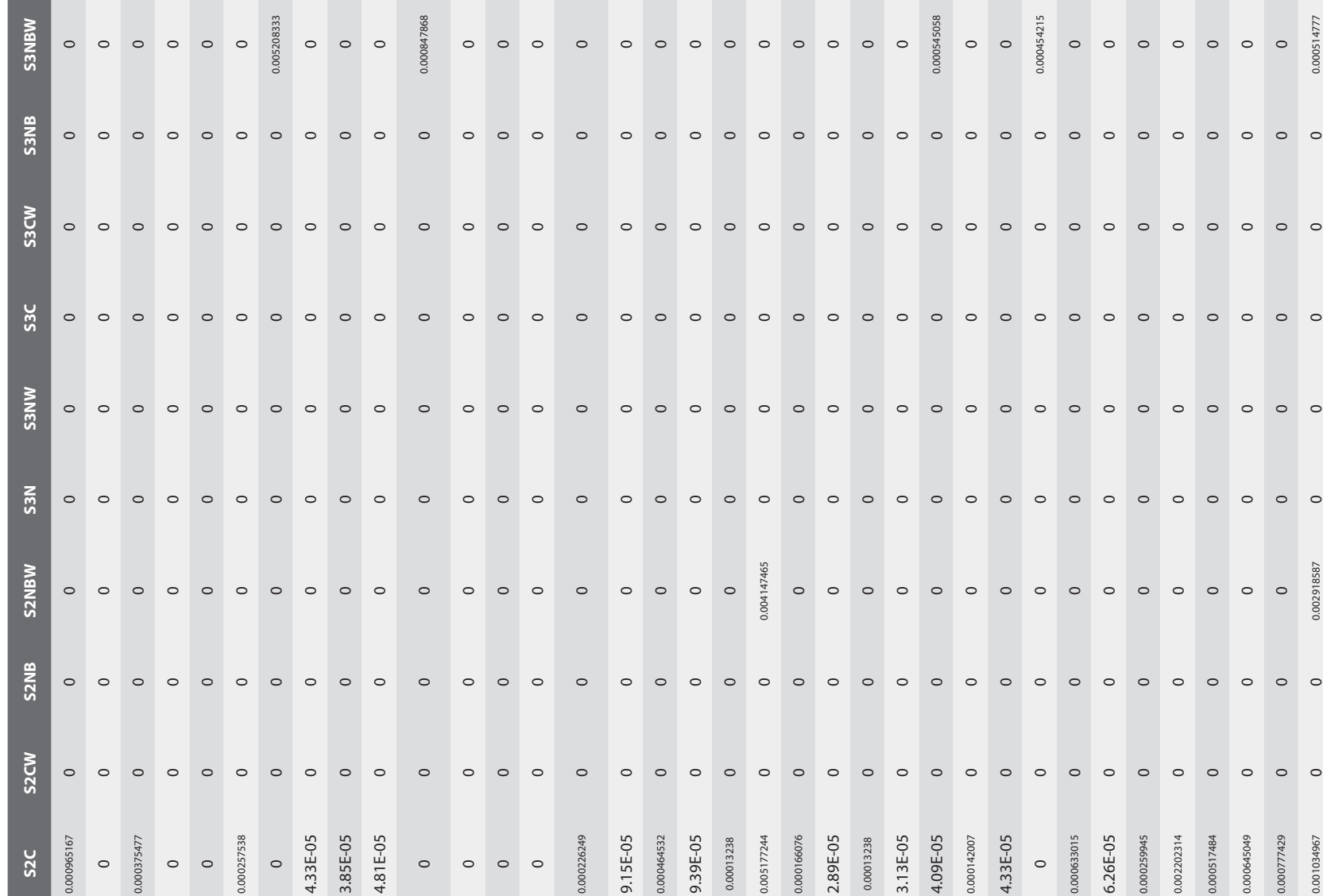

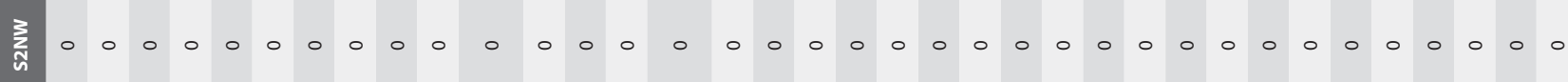

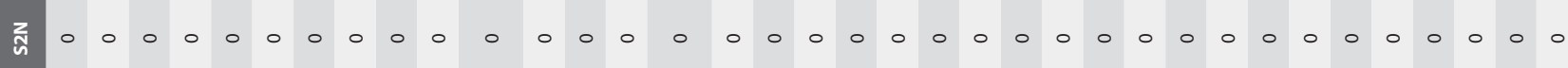

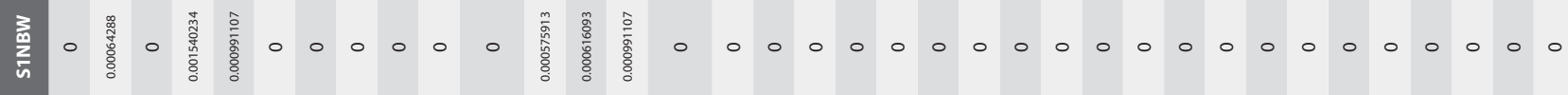
$\begin{array}{lllllllllllllllllllllllllllllllllllll}\frac{m}{2} & 0 & 0 & 0 & 0 & 0 & 0 & 0 & 0 & 0 & 0 & 0 & 0 & 0 & 0 & 0 & 0 & 0 & 0 & 0 & 0 & 0 & 0 & 0 & 0 & 0 & 0 & 0 & 0 & 0 & 0 & 0 & \frac{1}{2} & 0 & 0 & 0 & 0\end{array}$ $\begin{array}{llllllllllllllllllllllllllllllllllllll}\frac{n}{3} & 0 & 0 & 0 & 0 & 0 & 0 & 0 & 0 & 0 & 0 & 0 & 0 & 0 & 0 & 0 & 0 & 0 & 0 & 0 & 0 & 0 & 0 & 0 & 0 & 0 & 0 & 0 & 0 & 0 & 0 & 0 & 0 & 0 & 0 & 0 & 0\end{array}$ $\underline{n}$

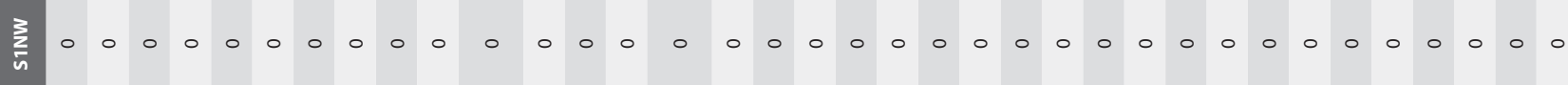

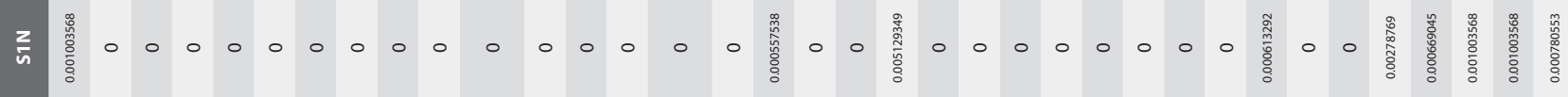

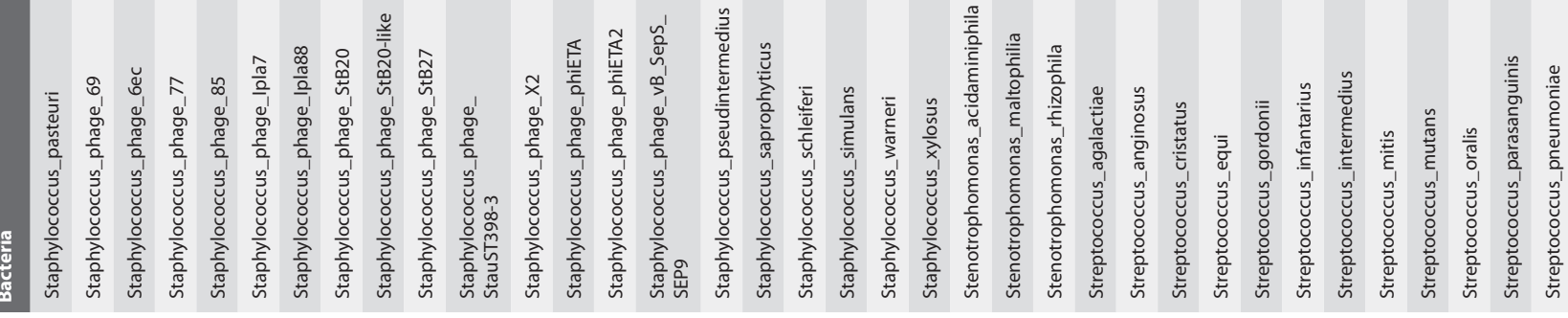




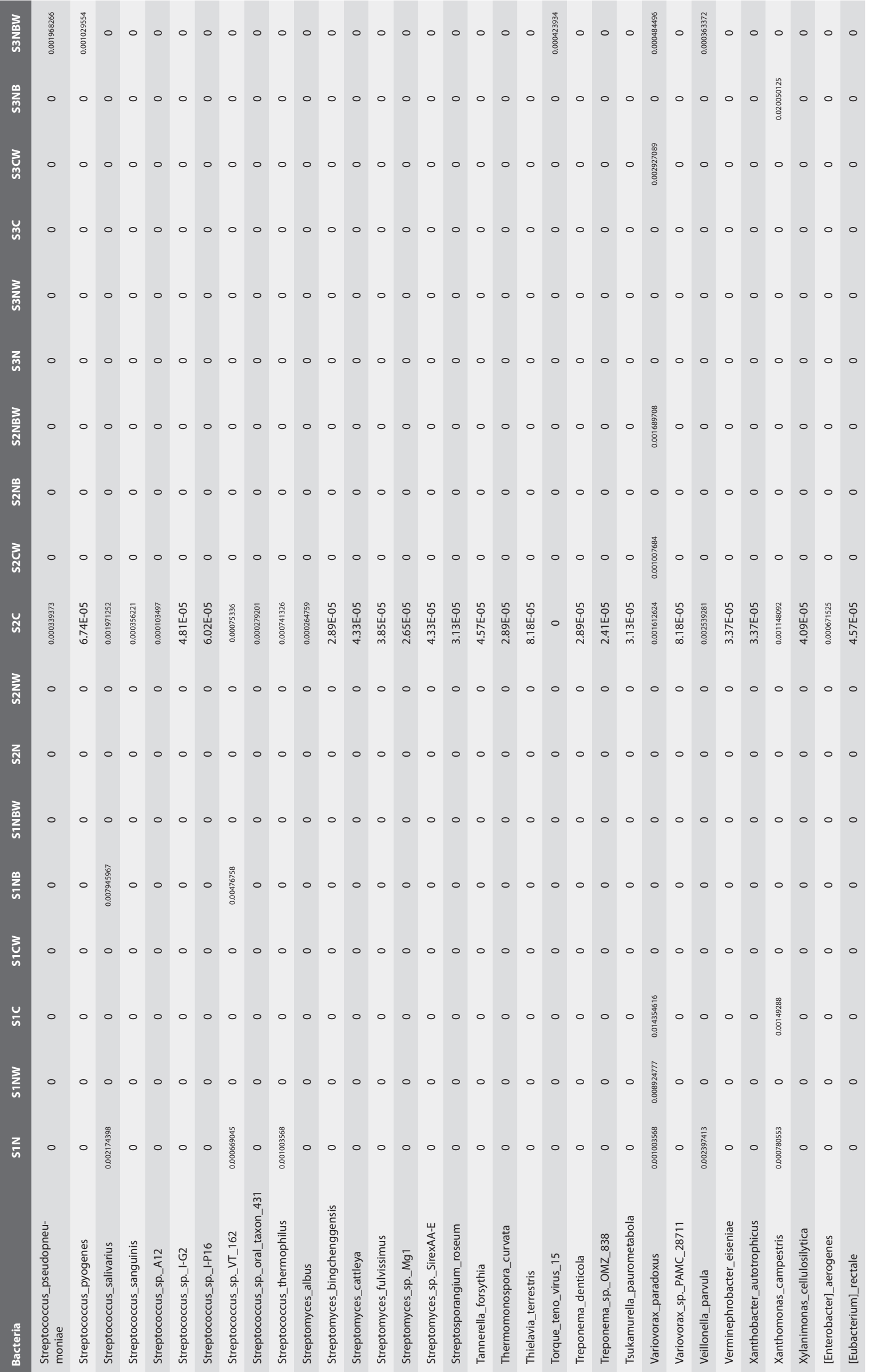



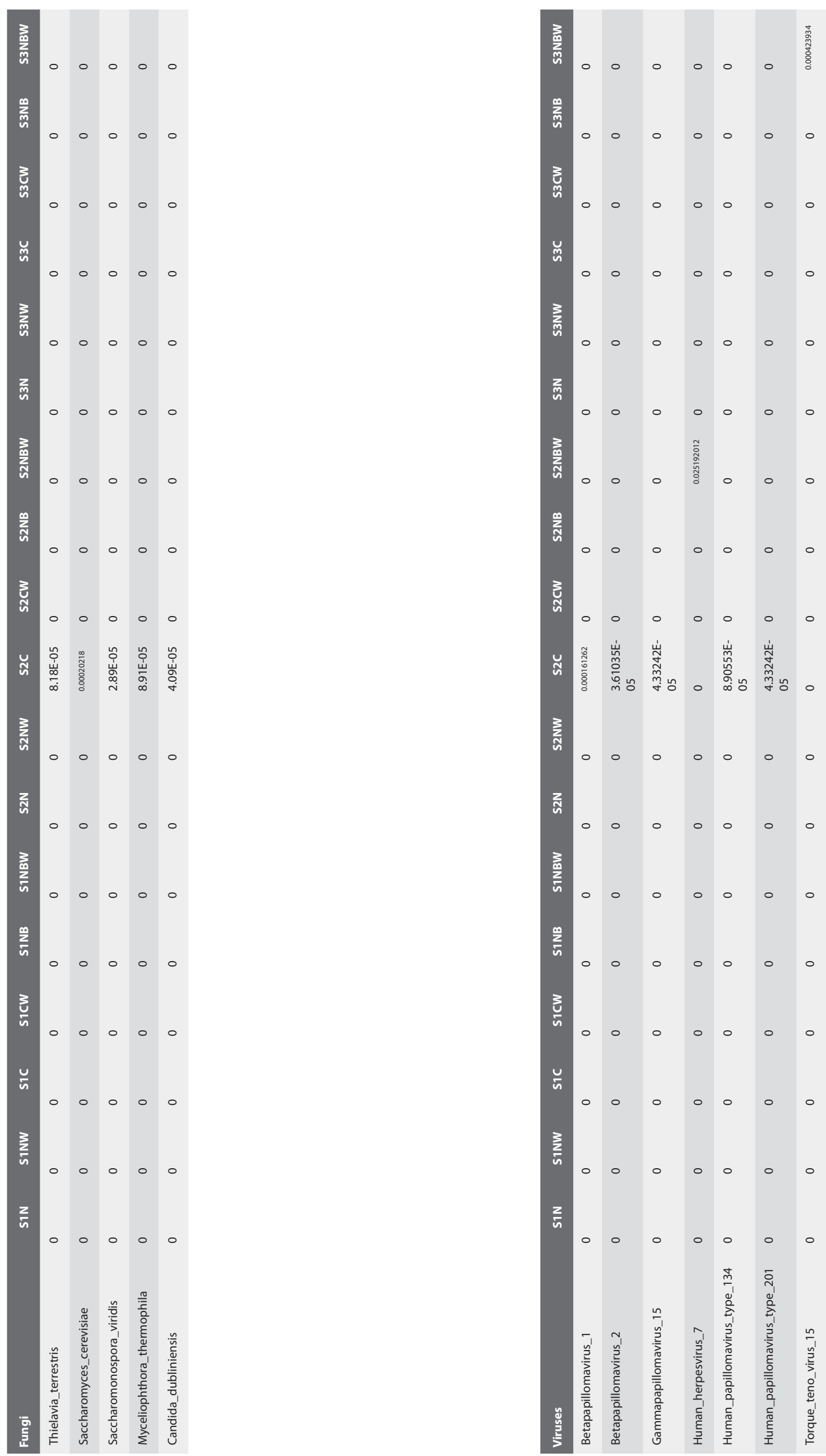
Figure S1A. Relative sequence abundance of Corynebacterium species and Corynebacterium-associated phage diversity recovered from metagenomic sequencing.

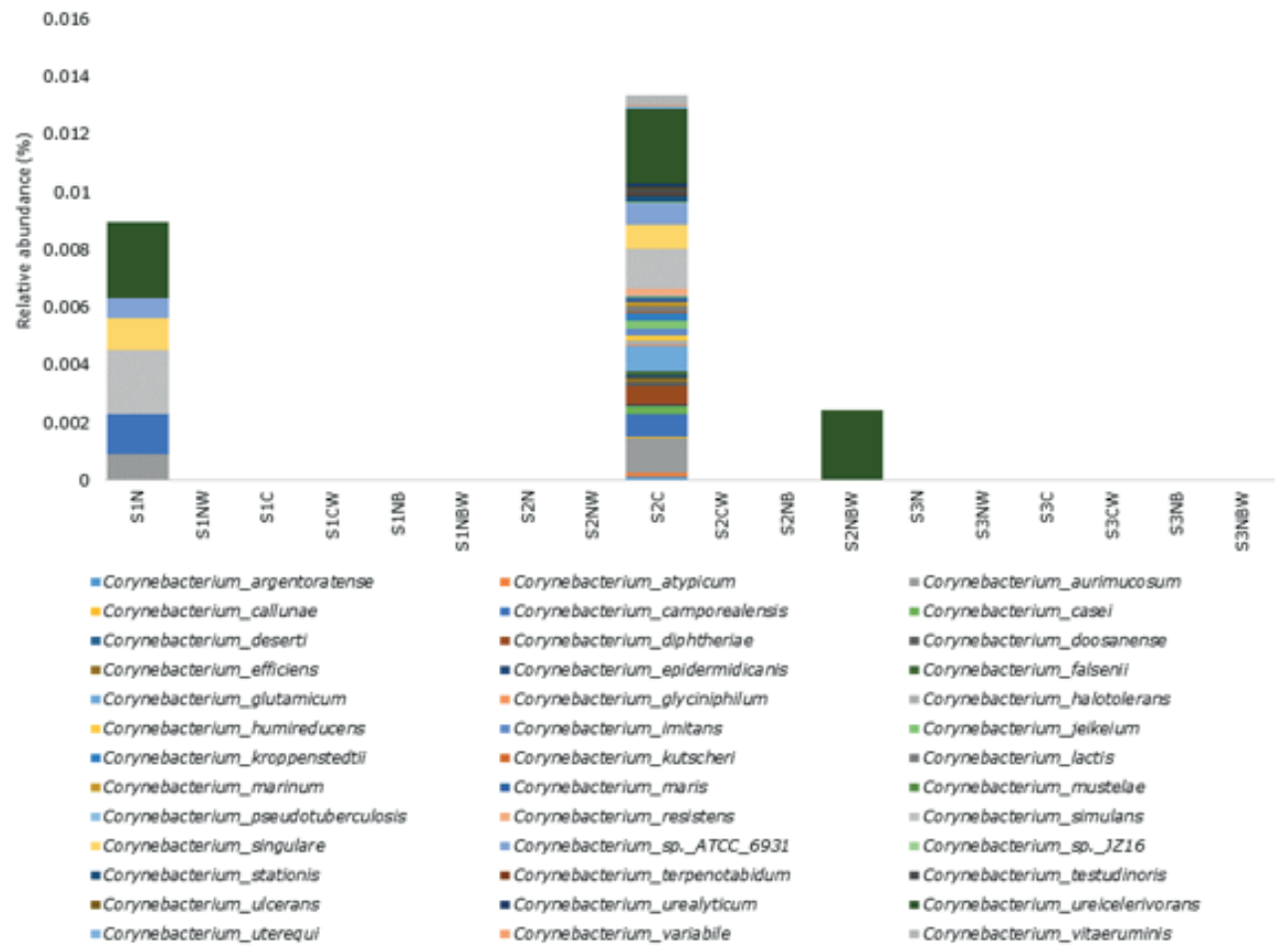

Figure S1B. Relative sequence abundance of Propionibacterium species and Propionibacterium -associated phage diversity recovered from metagenomic sequencing.

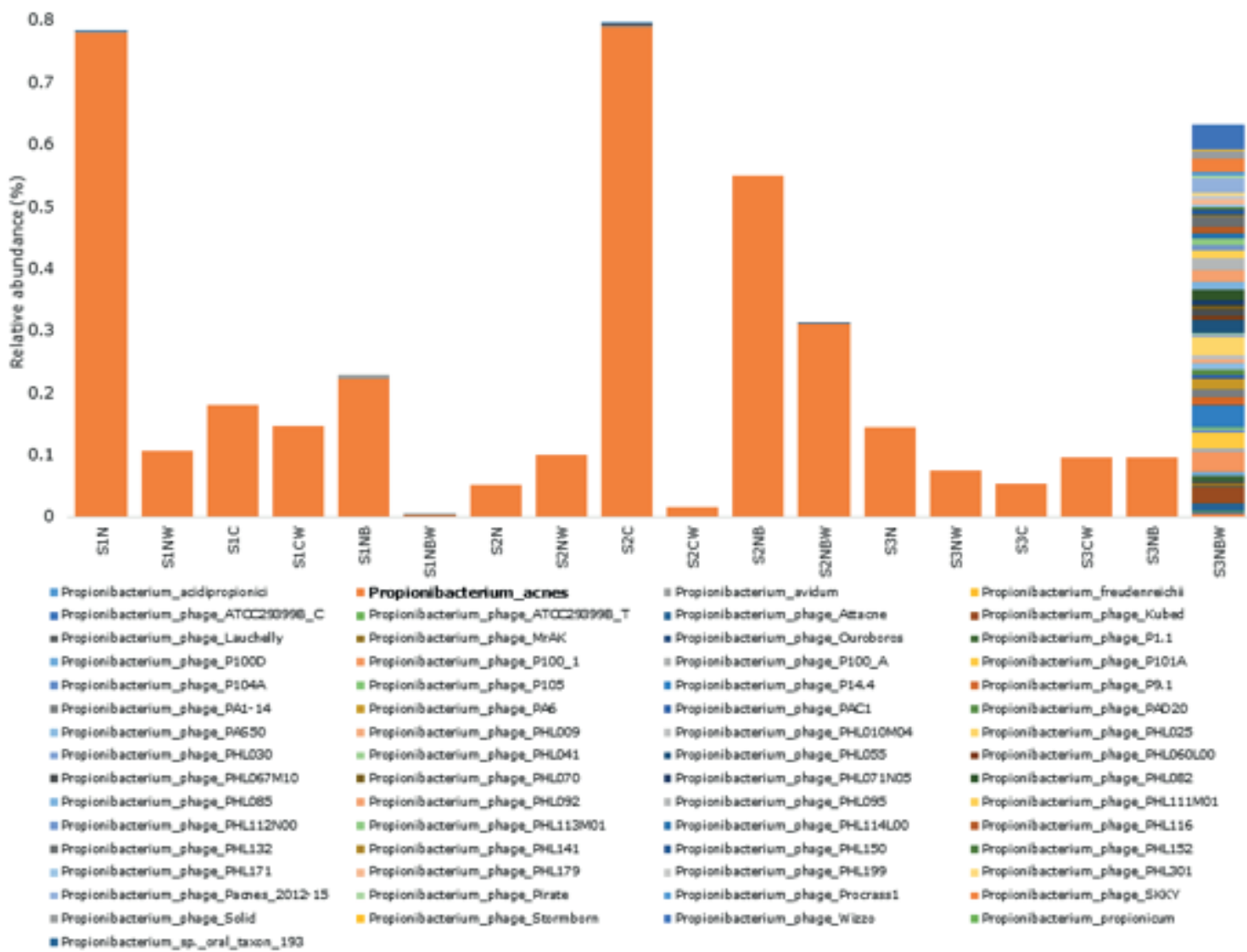


Figure S1C. Relative sequence abundance of Staphylococcus species and Staphylococcus-associated phage diversity recovered from metagenomic sequencing.

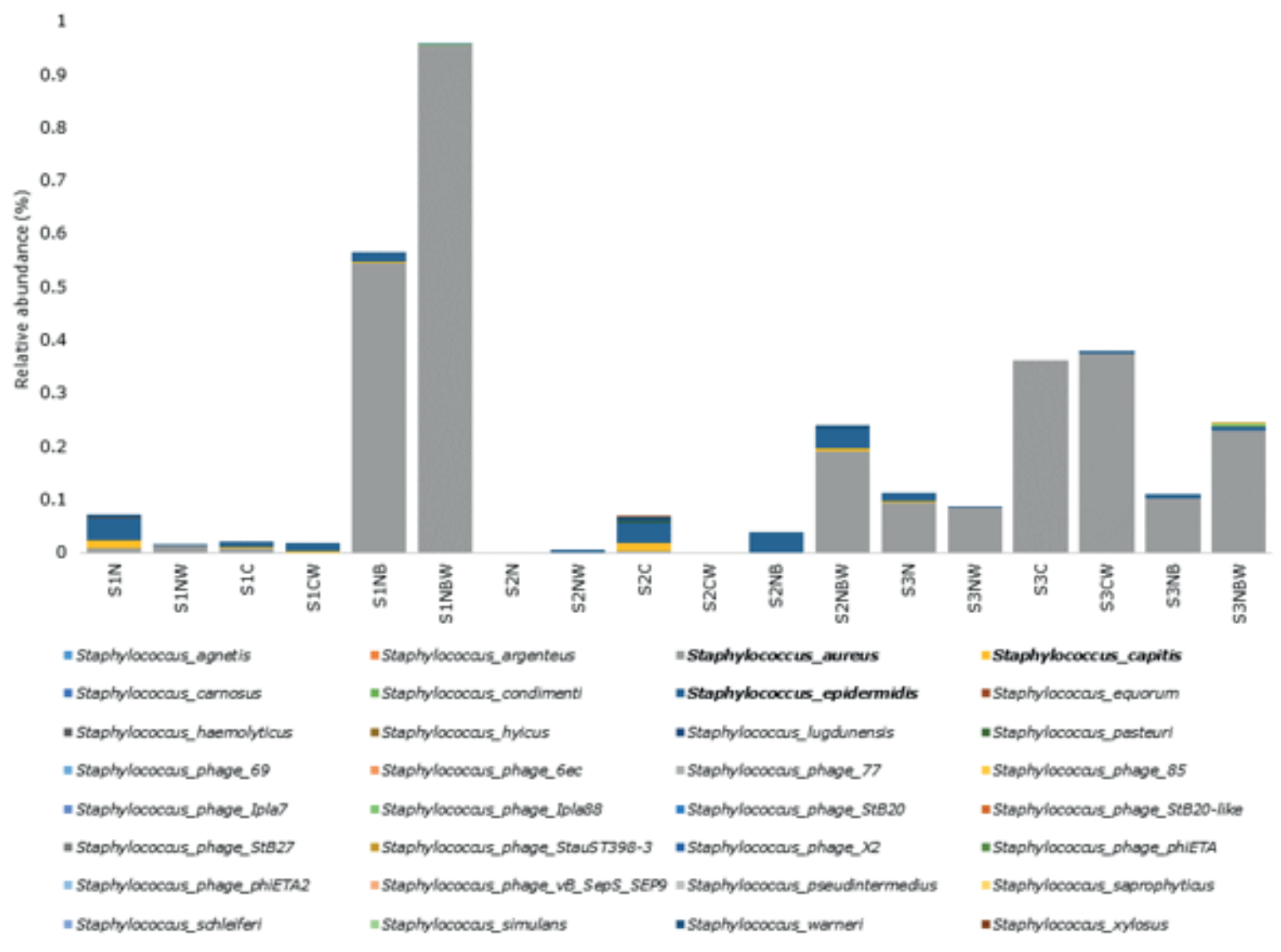

Figure S2. Phylogenomic tree for species-level identification constructed from a subset of 44 reference genomes. Phylogenetic inference was performed using FastTree v2.1.9 with the WAG $+\Gamma$ model of amino acid evolution and 100 bootstrap iterations to assess node support. The refined genome bin, identified as Propionibacterium acnes is highlighted. Scale bar represents $10 \%$ sequence divergence.

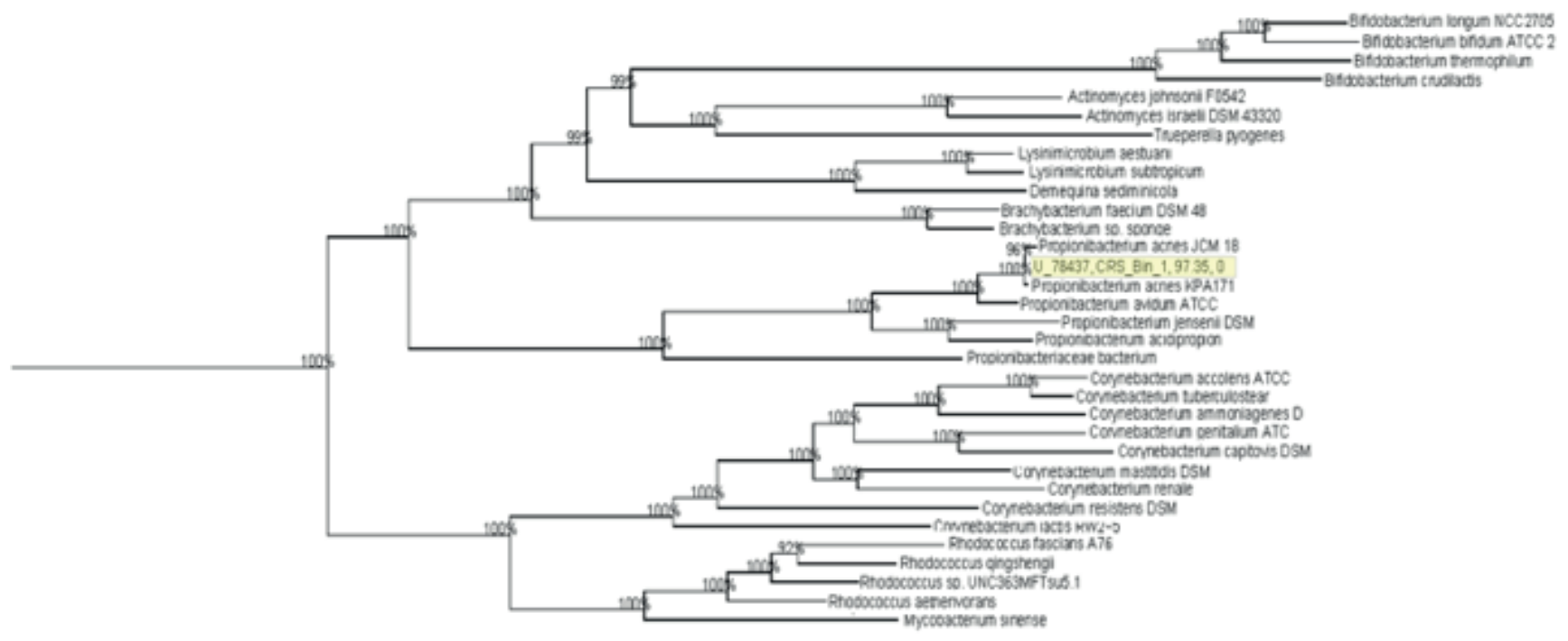


Figure S3. Assignments of gene function to overall metabolic reconstruction categories for the recovered Propionibacterium acnes genome.

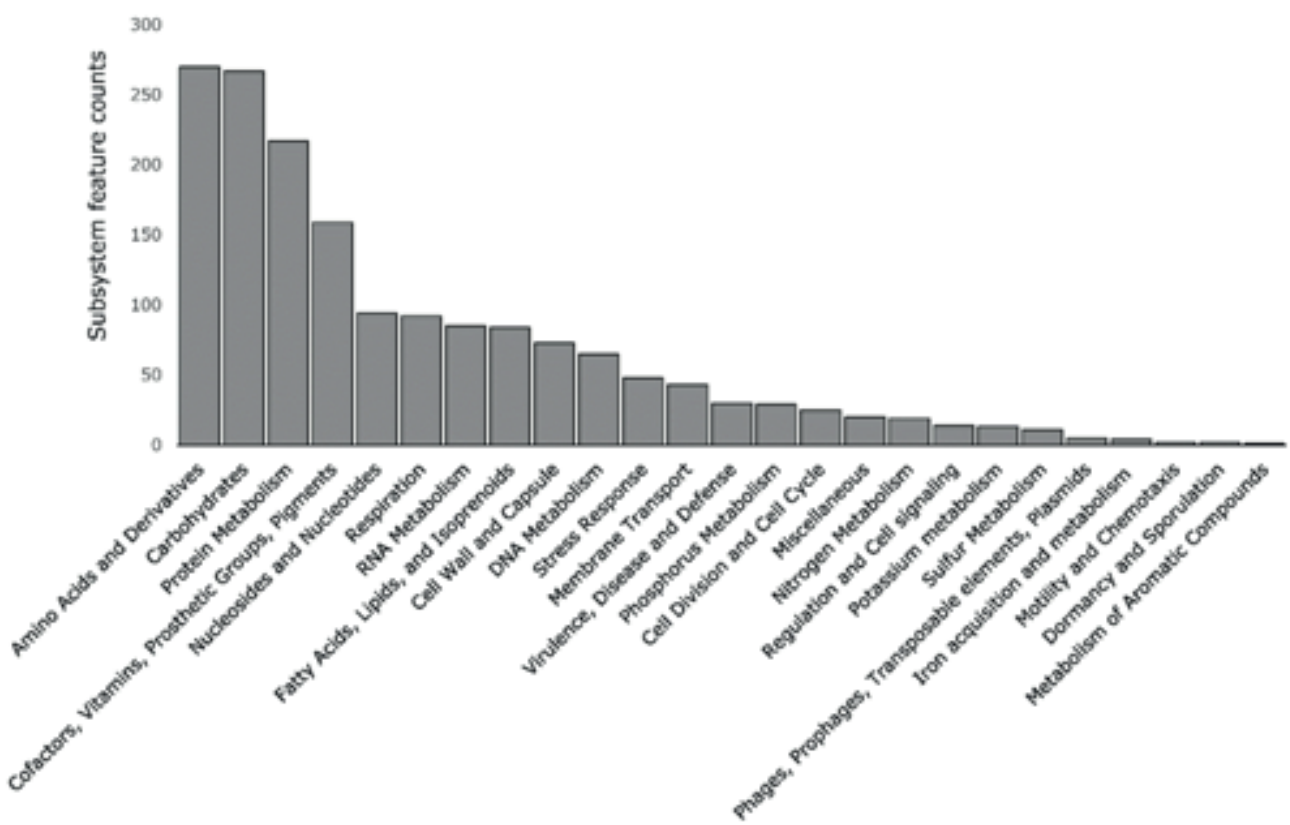

Subsystem category distribution

Table S3. List of differential gene pathways associated with the recovered Propionibacterium acnes genome compared with Propionibacterium acnes isolated strain KPA171202.

\begin{tabular}{|c|c|c|c|c|c|}
\hline Category & Subcategory & Subsystem & Role & $\begin{array}{c}\text { Presence in } \\
\text { recovered } \\
\text { P. acnes } \\
\text { genome }\end{array}$ & $\begin{array}{c}\text { Presence } \\
\text { P. acnes } \\
\text { KPA171202 }\end{array}$ \\
\hline $\begin{array}{l}\text { Amino Acids and } \\
\text { Derivatives }\end{array}$ & $\begin{array}{l}\text { Alanine, serine, and } \\
\text { glycine }\end{array}$ & $\begin{array}{l}\text { Glycine and Serine } \\
\text { Utilization }\end{array}$ & Serine transporter & yes & no \\
\hline $\begin{array}{l}\text { Amino Acids and } \\
\text { Derivatives }\end{array}$ & $\begin{array}{l}\text { Aromatic amino acids } \\
\text { and derivatives }\end{array}$ & $\begin{array}{l}\text { Chorismate: Interme- } \\
\text { diate for synthesis } \\
\text { of Tryptophan, PAPA } \\
\text { antibiotics, PABA, } \\
\text { 3-hydroxyanthranilate } \\
\text { and more. }\end{array}$ & $\begin{array}{l}\text { Isochorismate synthase (EC 5.4.4.2) of } \\
\text { siderophore biosynthesis }\end{array}$ & yes & no \\
\hline $\begin{array}{l}\text { Amino Acids and } \\
\text { Derivatives }\end{array}$ & $\begin{array}{l}\text { Branched-chain } \\
\text { amino acids }\end{array}$ & $\begin{array}{l}\text { Branched-Chain } \\
\text { Amino Acid Biosyn- } \\
\text { thesis }\end{array}$ & 2-isopropylmalate synthase (EC 2.3.3.13) & yes & no \\
\hline $\begin{array}{l}\text { Amino Acids and } \\
\text { Derivatives }\end{array}$ & $\begin{array}{l}\text { Branched-chain } \\
\text { amino acids }\end{array}$ & $\begin{array}{l}\text { Branched-Chain } \\
\text { Amino Acid Biosyn- } \\
\text { thesis }\end{array}$ & $\begin{array}{l}\text { 3-isopropylmalate dehydratase large } \\
\text { subunit (EC 4.2.1.33) }\end{array}$ & yes & no \\
\hline $\begin{array}{l}\text { Amino Acids and } \\
\text { Derivatives }\end{array}$ & $\begin{array}{l}\text { Branched-chain } \\
\text { amino acids }\end{array}$ & $\begin{array}{l}\text { Branched-Chain } \\
\text { Amino Acid Biosyn- } \\
\text { thesis }\end{array}$ & $\begin{array}{l}\text { 3-isopropylmalate dehydratase small } \\
\text { subunit (EC 4.2.1.33) }\end{array}$ & yes & no \\
\hline $\begin{array}{l}\text { Amino Acids and } \\
\text { Derivatives }\end{array}$ & $\begin{array}{l}\text { Branched-chain } \\
\text { amino acids }\end{array}$ & $\begin{array}{l}\text { Branched-Chain } \\
\text { Amino Acid Biosyn- } \\
\text { thesis }\end{array}$ & $\begin{array}{l}\text { 3-isopropylmalate dehydrogenase (EC } \\
1.1 .1 .85)\end{array}$ & yes & no \\
\hline $\begin{array}{l}\text { Amino Acids and } \\
\text { Derivatives }\end{array}$ & $\begin{array}{l}\text { Branched-chain } \\
\text { amino acids }\end{array}$ & $\begin{array}{l}\text { Branched-Chain } \\
\text { Amino Acid Biosyn- } \\
\text { thesis }\end{array}$ & $\begin{array}{l}\text { Leucine-responsive regulatory protein, } \\
\text { regulator for leucine (or Irp) regulon and } \\
\text { high-affinity branched-chain amino acid } \\
\text { transport system }\end{array}$ & yes & no \\
\hline
\end{tabular}




\begin{tabular}{|c|c|c|c|c|c|}
\hline Category & Subcategory & Subsystem & Role & $\begin{array}{l}\text { Presence in } \\
\text { recovered } \\
\text { P. acnes } \\
\text { genome }\end{array}$ & $\begin{array}{c}\text { Presence } \\
\text { P. acnes } \\
\text { KPA171202 }\end{array}$ \\
\hline $\begin{array}{l}\text { Amino Acids and } \\
\text { Derivatives }\end{array}$ & $\begin{array}{l}\text { Glutamine, glutamate, } \\
\text { aspartate, asparagine; } \\
\text { ammonia assimilation }\end{array}$ & $\begin{array}{l}\text { Glutamine, Glutamate, } \\
\text { Aspartate and Aspara- } \\
\text { gine Biosynthesis }\end{array}$ & L-asparaginase I, cytoplasmic (EC 3.5.1.1) & yes & no \\
\hline $\begin{array}{l}\text { Amino Acids and } \\
\text { Derivatives }\end{array}$ & $\begin{array}{l}\text { Lysine, threonine, } \\
\text { methionine, and } \\
\text { cysteine }\end{array}$ & $\begin{array}{l}\text { Lysine Biosynthesis } \\
\text { DAP Pathway }\end{array}$ & $\begin{array}{l}\text { 2,3,4,5-tetrahydropyridine-2,6-dicar- } \\
\text { boxylate } \mathrm{N} \text {-acetyltransferase (EC 2.3.1.89) }\end{array}$ & yes & no \\
\hline Carbohydrates & Aminosugars & $\begin{array}{l}\text { Chitin and } \mathrm{N} \text { - } \\
\text { acetylglucosamine } \\
\text { utilization }\end{array}$ & Beta-hexosaminidase (EC 3.2.1.52) & yes & no \\
\hline Carbohydrates & Aminosugars & $\begin{array}{l}\text { Chitin and } \mathrm{N} \text { - } \\
\text { acetylglucosamine } \\
\text { utilization }\end{array}$ & $\begin{array}{l}\mathrm{N} \text {-Acetyl-D-glucosamine } \mathrm{ABC} \text { transport } \\
\text { system, sugar-binding protein }\end{array}$ & yes & no \\
\hline Carbohydrates & $\begin{array}{l}\text { Central carbohydrate } \\
\text { metabolism }\end{array}$ & $\begin{array}{l}\text { Pyruvate metabo- } \\
\text { lism II: acetyl-CoA, } \\
\text { acetogenesis from } \\
\text { pyruvate }\end{array}$ & $\begin{array}{l}\text { Acetyl-coenzyme A synthetase (EC } \\
6.2 .1 .1 \text { ) }\end{array}$ & yes & no \\
\hline Carbohydrates & $\begin{array}{l}\text { Central carbohydrate } \\
\text { metabolism }\end{array}$ & TCA Cycle & Malate dehydrogenase (EC 1.1.1.37) & yes & no \\
\hline Carbohydrates & $\begin{array}{l}\text { Di- and oligosaccha- } \\
\text { rides }\end{array}$ & $\begin{array}{l}\text { Beta-Glucoside Meta- } \\
\text { bolism }\end{array}$ & Beta-glucosidase (EC 3.2.1.21) & yes & no \\
\hline Carbohydrates & $\begin{array}{l}\mathrm{Di}-\text { and oligosaccha- } \\
\text { rides }\end{array}$ & $\begin{array}{l}\text { Beta-Glucoside Meta- } \\
\text { bolism }\end{array}$ & $\begin{array}{l}\text { Beta-glucoside bgl operon antitermina- } \\
\text { tor, BglG family }\end{array}$ & yes & no \\
\hline Carbohydrates & $\begin{array}{l}\mathrm{Di}-\text { and oligosaccha- } \\
\text { rides }\end{array}$ & $\begin{array}{l}\text { Beta-Glucoside Meta- } \\
\text { bolism }\end{array}$ & $\begin{array}{l}\text { PTS system, beta-glucoside-specific IIB } \\
\text { component (EC 2.7.1.69) }\end{array}$ & yes & no \\
\hline Carbohydrates & $\begin{array}{l}\text { Di- and oligosaccha- } \\
\text { rides }\end{array}$ & $\begin{array}{l}\text { Beta-Glucoside Meta- } \\
\text { bolism }\end{array}$ & $\begin{array}{l}\text { PTS system, diacetylchitobiose-specific } \\
\text { IIB component (EC 2.7.1.69) }\end{array}$ & yes & no \\
\hline Carbohydrates & $\begin{array}{l}\text { Di- and oligosaccha- } \\
\text { rides }\end{array}$ & $\begin{array}{l}\text { Lactose and Galactose } \\
\text { Uptake and Utilization }\end{array}$ & Galactokinase (EC 2.7.1.6) & yes & no \\
\hline Carbohydrates & $\begin{array}{l}\text { Di- and oligosaccha- } \\
\text { rides }\end{array}$ & $\begin{array}{l}\text { Maltose and Malto- } \\
\text { dextrin Utilization }\end{array}$ & Neopullulanase (EC 3.2.1.135) & yes & no \\
\hline Carbohydrates & $\begin{array}{l}\text { Di- and oligosaccha- } \\
\text { rides }\end{array}$ & Trehalose Biosynthesis & $\begin{array}{l}\text { Malto-oligosyltrehalose trehalohydrolase } \\
\text { (EC 3.2.1.141) }\end{array}$ & yes & no \\
\hline Carbohydrates & Fermentation & $\begin{array}{l}\text { Acetolactate synthase } \\
\text { subunits }\end{array}$ & $\begin{array}{l}\text { Acetolactate synthase large subunit (EC } \\
2.2 .1 .6 \text { ) }\end{array}$ & yes & no \\
\hline Carbohydrates & Fermentation & $\begin{array}{l}\text { Acetolactate synthase } \\
\text { subunits }\end{array}$ & $\begin{array}{l}\text { Acetolactate synthase small subunit (EC } \\
2.2 .1 .6 \text { ) }\end{array}$ & yes & no \\
\hline Carbohydrates & Monosaccharides & $\begin{array}{l}\text { D-Tagatose and Galac- } \\
\text { titol Utilization }\end{array}$ & $\begin{array}{l}\text { PTS system, galactitol-specific IIB compo- } \\
\text { nent (EC 2.7.1.69) }\end{array}$ & yes & no \\
\hline Carbohydrates & Monosaccharides & $\begin{array}{l}\text { D-Tagatose and Galac- } \\
\text { titol Utilization }\end{array}$ & $\begin{array}{l}\text { PTS system, galactitol-specific IIC compo- } \\
\text { nent (EC 2.7.1.69) }\end{array}$ & yes & no \\
\hline Carbohydrates & Monosaccharides & $\begin{array}{l}\text { Deoxyribose and } \\
\text { Deoxynucleoside } \\
\text { Catabolism }\end{array}$ & $\begin{array}{l}\text { Deoxyribonucleoside regulator DeoR } \\
\text { (transcriptional repressor) }\end{array}$ & yes & no \\
\hline Carbohydrates & Monosaccharides & $\begin{array}{l}\text { Deoxyribose and } \\
\text { Deoxynucleoside } \\
\text { Catabolism }\end{array}$ & $\begin{array}{l}\text { Deoxyribose-phosphate aldolase (EC } \\
4.1 .2 .4 \text { ) }\end{array}$ & yes & no \\
\hline Carbohydrates & Monosaccharides & $\begin{array}{l}\text { Deoxyribose and } \\
\text { Deoxynucleoside } \\
\text { Catabolism }\end{array}$ & Thymidine phosphorylase (EC 2.4.2.4) & yes & no \\
\hline Carbohydrates & Monosaccharides & Mannose Metabolism & Alpha-mannosidase (EC 3.2.1.24) & yes & no \\
\hline Carbohydrates & Monosaccharides & Mannose Metabolism & Beta-mannosidase (EC 3.2.1.25) & yes & no \\
\hline Carbohydrates & Monosaccharides & Mannose Metabolism & $\begin{array}{l}\text { Mannose-1-phosphate guanylyltrans- } \\
\text { ferase (GDP) (EC 2.7.7.22) }\end{array}$ & yes & no \\
\hline Carbohydrates & Monosaccharides & Mannose Metabolism & $\begin{array}{l}\text { Mannose-6-phosphate isomerase (EC } \\
\text { 5.3.1.8) }\end{array}$ & yes & no \\
\hline
\end{tabular}




\begin{tabular}{|c|c|c|c|c|c|}
\hline Category & Subcategory & Subsystem & Role & $\begin{array}{l}\text { Presence in } \\
\text { recovered } \\
\text { P. acnes } \\
\text { genome }\end{array}$ & $\begin{array}{l}\text { Presence } \\
\text { P. acnes } \\
\text { KPA171202 }\end{array}$ \\
\hline Carbohydrates & Monosaccharides & Mannose Metabolism & Phosphomannomutase (EC 5.4.2.8) & yes & no \\
\hline Carbohydrates & Polysaccharides & $\begin{array}{l}\text { Alpha-Amylase locus } \\
\text { in Streptocococcus }\end{array}$ & $\begin{array}{l}\text { Maltose/maltodextrin } A B C \text { transporter, } \\
\text { substrate binding periplasmic protein } \\
\text { MalE }\end{array}$ & yes & no \\
\hline Carbohydrates & Polysaccharides & $\begin{array}{l}\text { Alpha-Amylase locus } \\
\text { in Streptocococcus }\end{array}$ & putative esterase & yes & no \\
\hline Carbohydrates & Sugar alcohols & $\begin{array}{l}\text { Glycerol and Glycerol- } \\
\text { 3-phosphate Uptake } \\
\text { and Utilization }\end{array}$ & $\begin{array}{l}\text { Glycerol-3-phosphate dehydrogenase } \\
{[\mathrm{NAD}(\mathrm{P})+](\mathrm{EC} \text { 1.1.1.94) }}\end{array}$ & yes & no \\
\hline Carbohydrates & no subcategory & $\begin{array}{l}\text { Lacto-N-Biose I and } \\
\text { Galacto-N-Biose Meta- } \\
\text { bolic Pathway }\end{array}$ & UDP-glucose 4-epimerase (EC 5.1.3.2) & yes & no \\
\hline Cell Wall and Capsule & $\begin{array}{l}\text { Capsular and extracel- } \\
\text { lular polysacchrides }\end{array}$ & $\begin{array}{l}\text { Lipid-linked oligosac- } \\
\text { charide synthesis } \\
\text { related cluster }\end{array}$ & $\begin{array}{l}\text { Exoenzymes regulatory protein AepA in } \\
\text { lipid-linked oligosaccharide synthesis } \\
\text { cluster }\end{array}$ & yes & no \\
\hline Cell Wall and Capsule & $\begin{array}{l}\text { Capsular and extracel- } \\
\text { lular polysacchrides }\end{array}$ & Sialic Acid Metabolism & $\begin{array}{l}\text { Sialic acid utilization regulator, RpiR } \\
\text { family }\end{array}$ & yes & no \\
\hline Cell Wall and Capsule & no subcategory & $\begin{array}{l}\text { Peptidoglycan Biosyn- } \\
\text { thesis }\end{array}$ & Rare lipoprotein A precursor & yes & no \\
\hline $\begin{array}{l}\text { Clustering-based } \\
\text { subsystems }\end{array}$ & $\begin{array}{l}\text { Cytochrome bioge- } \\
\text { nesis }\end{array}$ & $\begin{array}{l}\text { CBSS- } \\
\text { 196164.1.peg. } 1690\end{array}$ & cytochrome oxidase assembly protein & yes & no \\
\hline $\begin{array}{l}\text { Clustering-based } \\
\text { subsystems }\end{array}$ & $\begin{array}{l}\text { Isoprenoid/cell wall } \\
\text { biosynthesis: PREDIC- } \\
\text { TED UNDECAPRENYL } \\
\text { DIPHOSPHATE } \\
\text { PHOSPHATASE }\end{array}$ & $\begin{array}{l}\text { CBSS- } \\
\text { 83331.1.peg.3039 }\end{array}$ & $\begin{array}{l}\text { Undecaprenyl diphosphate synthase (EC } \\
\text { 2.5.1.31) }\end{array}$ & yes & no \\
\hline $\begin{array}{l}\text { Clustering-based } \\
\text { subsystems }\end{array}$ & no subcategory & Bacterial Cell Division & Cell division protein FtsQ & yes & no \\
\hline $\begin{array}{l}\text { Clustering-based } \\
\text { subsystems }\end{array}$ & no subcategory & Bacterial Cell Division & Septum formation protein Maf & yes & no \\
\hline $\begin{array}{l}\text { Clustering-based } \\
\text { subsystems }\end{array}$ & no subcategory & Bacterial Cell Division & Septum site-determining protein MinD & yes & no \\
\hline $\begin{array}{l}\text { Clustering-based } \\
\text { subsystems }\end{array}$ & no subcategory & $\begin{array}{l}\text { CBSS- } \\
\text { 228410.1.peg.134 }\end{array}$ & $\begin{array}{l}\text { DNA polymerase III epsilon subunit (EC } \\
2.7 .7 .7 \text { ) }\end{array}$ & yes & no \\
\hline $\begin{array}{l}\text { Clustering-based } \\
\text { subsystems }\end{array}$ & no subcategory & $\begin{array}{l}\text { CBSS- } \\
\text { 228410.1.peg.134 }\end{array}$ & $\begin{array}{l}\text { Hydroxyacylglutathione hydrolase (EC } \\
\text { 3.1.2.6) }\end{array}$ & yes & no \\
\hline $\begin{array}{l}\text { Clustering-based } \\
\text { subsystems }\end{array}$ & no subcategory & $\begin{array}{l}\text { CBSS- } \\
\text { 257314.1.peg.752 }\end{array}$ & $\begin{array}{l}\text { Adenine-specific methyltransferase (EC } \\
2.1 .1 .72 \text { ) }\end{array}$ & yes & no \\
\hline $\begin{array}{l}\text { Clustering-based } \\
\text { subsystems }\end{array}$ & no subcategory & $\begin{array}{l}\text { CBSS- } \\
\text { 469378.4.peg. } 430\end{array}$ & FIG002344: Hydrolase (HAD superfamily) & yes & no \\
\hline $\begin{array}{l}\text { Clustering-based } \\
\text { subsystems }\end{array}$ & no subcategory & $\begin{array}{l}\text { Conserved gene clus- } \\
\text { ter associated with } \\
\text { Met-tRNA formyl- } \\
\text { transferase }\end{array}$ & $\begin{array}{l}\text { Serine/threonine protein kinase PrkC, } \\
\text { regulator of stationary phase }\end{array}$ & yes & no \\
\hline $\begin{array}{l}\text { Clustering-based } \\
\text { subsystems }\end{array}$ & no subcategory & EC699-706 & FIG137478: Hypothetical protein YbgI & yes & no \\
\hline $\begin{array}{l}\text { Cofactors, Vitamins, } \\
\text { Prosthetic Groups, } \\
\text { Pigments }\end{array}$ & Biotin & Biotin biosynthesis & $\begin{array}{l}\text { Long-chain-fatty-acid--CoA ligase (EC } \\
6.2 .1 .3 \text { ) }\end{array}$ & yes & no \\
\hline $\begin{array}{l}\text { Cofactors, Vitamins, } \\
\text { Prosthetic Groups, } \\
\text { Pigments }\end{array}$ & Coenzyme A & $\begin{array}{l}\text { Coenzyme A Biosyn- } \\
\text { thesis }\end{array}$ & $\begin{array}{l}\text { 2-dehydropantoate 2-reductase (EC } \\
\text { 1.1.1.169) }\end{array}$ & yes & no \\
\hline $\begin{array}{l}\text { Cofactors, Vitamins, } \\
\text { Prosthetic Groups, } \\
\text { Pigments }\end{array}$ & Quinone cofactors & $\begin{array}{l}\text { Menaquinone and } \\
\text { Phylloquinone Biosyn- } \\
\text { thesis -- gjo }\end{array}$ & $\begin{array}{l}\text { 1,4-dihydroxy-2-naphthoyl-CoA hy- } \\
\text { drolase (EC 3.1.2.28) in phylloquinone } \\
\text { biosynthesis }\end{array}$ & yes & no \\
\hline DNA Metabolism & CRISPs & CRISPRs & CRISPR-associated protein Cas1 & yes & no \\
\hline
\end{tabular}




\begin{tabular}{|c|c|c|c|c|c|}
\hline Category & Subcategory & Subsystem & Role & $\begin{array}{c}\text { Presence in } \\
\text { recovered } \\
\text { P. acnes } \\
\text { genome }\end{array}$ & $\begin{array}{l}\text { Presence } \\
\text { P. acnes } \\
\text { KPA171202 }\end{array}$ \\
\hline DNA Metabolism & DNA repair & $\begin{array}{l}\text { DNA Repair Base } \\
\text { Excision }\end{array}$ & DNA ligase (EC 6.5.1.2) & yes & no \\
\hline DNA Metabolism & DNA repair & $\begin{array}{l}\text { DNA Repair Base } \\
\text { Excision }\end{array}$ & $\begin{array}{l}\text { DNA-3-methyladenine glycosylase II (EC } \\
3.2 .2 .21 \text { ) }\end{array}$ & yes & no \\
\hline DNA Metabolism & DNA repair & DNA repair, bacterial & $\begin{array}{l}\text { SOS-response repressor and protease } \\
\text { LexA (EC 3.4.21.88) }\end{array}$ & yes & no \\
\hline DNA Metabolism & DNA repair & $\begin{array}{l}\text { DNA repair, bacterial } \\
\text { RecFOR pathway }\end{array}$ & ATP-dependent DNA helicase RecQ & yes & no \\
\hline DNA Metabolism & no subcategory & $\begin{array}{l}\text { Restriction-Modificati- } \\
\text { on System }\end{array}$ & $\begin{array}{l}\text { Putative predicted metal-dependent } \\
\text { hydrolase }\end{array}$ & yes & no \\
\hline DNA Metabolism & no subcategory & $\begin{array}{l}\text { Restriction-Modificati- } \\
\text { on System }\end{array}$ & $\begin{array}{l}\text { Type III restriction-modification system } \\
\text { methylation subunit (EC 2.1.1.72) }\end{array}$ & yes & no \\
\hline $\begin{array}{l}\text { Fatty Acids, Lipids, } \\
\text { and Isoprenoids }\end{array}$ & Fatty acids & $\begin{array}{l}\text { Fatty Acid Biosynthe- } \\
\text { sis FASII }\end{array}$ & $\begin{array}{l}\text { 4\&\#39;-phosphopantetheinyl transferase } \\
\text { (EC 2.7.8.-) }\end{array}$ & yes & no \\
\hline $\begin{array}{l}\text { Fatty Acids, Lipids, } \\
\text { and Isoprenoids }\end{array}$ & Fatty acids & $\begin{array}{l}\text { Fatty Acid Biosynthe- } \\
\text { sis FASII }\end{array}$ & $\begin{array}{l}\text { Acetyl-coenzyme A carboxyl transferase } \\
\text { alpha chain (EC 6.4.1.2) }\end{array}$ & yes & no \\
\hline $\begin{array}{l}\text { Fatty Acids, Lipids, } \\
\text { and Isoprenoids }\end{array}$ & Fatty acids & $\begin{array}{l}\text { Fatty Acid Biosynthe- } \\
\text { sis FASII }\end{array}$ & $\begin{array}{l}\text { Acetyl-coenzyme A carboxyl transferase } \\
\text { beta chain (EC 6.4.1.2) }\end{array}$ & yes & no \\
\hline $\begin{array}{l}\text { Fatty Acids, Lipids, } \\
\text { and Isoprenoids }\end{array}$ & Phospholipids & Cardiolipin synthesis & Cardiolipin synthetase (EC 2.7.8.-) & yes & no \\
\hline Membrane Transport & $\mathrm{ABC}$ transporters & $\begin{array}{l}\text { ABC transporter di- } \\
\text { peptide (TC 3.A.1.5.2) }\end{array}$ & $\begin{array}{l}\text { Dipeptide transport system permease } \\
\text { protein DppB (TC 3.A.1.5.2) }\end{array}$ & yes & no \\
\hline Membrane Transport & $\mathrm{ABC}$ transporters & $\begin{array}{l}\text { ABC transporter di- } \\
\text { peptide (TC 3.A.1.5.2) }\end{array}$ & $\begin{array}{l}\text { Dipeptide transport system permease } \\
\text { protein DppC (TC 3.A.1.5.2) }\end{array}$ & yes & no \\
\hline Membrane Transport & $\mathrm{ABC}$ transporters & $\begin{array}{l}\text { ABC transporter di- } \\
\text { peptide (TC 3.A.1.5.2) }\end{array}$ & $\begin{array}{l}\text { Dipeptide-binding } \mathrm{ABC} \text { transporter, pe- } \\
\text { riplasmic substrate-binding component } \\
\text { (TC 3.A.1.5.2) }\end{array}$ & yes & no \\
\hline Membrane Transport & $A B C$ transporters & $\begin{array}{l}\text { ABC transporter oligo- } \\
\text { peptide (TC 3.A.1.5.1) }\end{array}$ & $\begin{array}{l}\text { Oligopeptide transport ATP-binding } \\
\text { protein OppF (TC 3.A.1.5.1) }\end{array}$ & yes & no \\
\hline Nitrogen Metabolism & Denitrification & $\begin{array}{l}\text { Denitrifying reductase } \\
\text { gene clusters }\end{array}$ & $\begin{array}{l}\text { Copper-containing nitrite reductase (EC } \\
1.7 .2 .1 \text { ) }\end{array}$ & yes & no \\
\hline Nitrogen Metabolism & no subcategory & Ammonia assimilation & $\begin{array}{l}\text { Glutamate synthase [NADPH] large chain } \\
\text { (EC 1.4.1.13) }\end{array}$ & yes & no \\
\hline $\begin{array}{l}\text { Nucleosides and } \\
\text { Nucleotides }\end{array}$ & Purines & $\begin{array}{l}\text { A hypothetical } \\
\text { coupled to de Novo } \\
\text { Purine Biosynthesis }\end{array}$ & $\begin{array}{l}\text { FIG021574: Possible membrane protein } \\
\text { related to de Novo purine biosynthesis }\end{array}$ & yes & no \\
\hline $\begin{array}{l}\text { Nucleosides and } \\
\text { Nucleotides }\end{array}$ & Purines & Purine conversions & Nucleotide pyrophosphatase (EC 3.6.1.9) & yes & no \\
\hline $\begin{array}{l}\text { Nucleosides and } \\
\text { Nucleotides }\end{array}$ & Pyrimidines & $\begin{array}{l}\text { De Novo Pyrimidine } \\
\text { Synthesis }\end{array}$ & Uracil permease & yes & no \\
\hline $\begin{array}{l}\text { Phages, Prophages, } \\
\text { Transposable ele- } \\
\text { ments, Plasmids }\end{array}$ & Phages, Prophages & $\begin{array}{l}\text { Phage packaging } \\
\text { machinery }\end{array}$ & Phage terminase, large subunit & yes & no \\
\hline $\begin{array}{l}\text { Phosphorus Meta- } \\
\text { bolism }\end{array}$ & no subcategory & $\begin{array}{l}\text { Phosphate metabo- } \\
\text { lism }\end{array}$ & $\begin{array}{l}\text { Pyrophosphate-energized proton pump } \\
\text { (EC 3.6.1.1) }\end{array}$ & yes & no \\
\hline $\begin{array}{l}\text { Potassium metabo- } \\
\text { lism }\end{array}$ & no subcategory & $\begin{array}{l}\text { Potassium homeo- } \\
\text { stasis }\end{array}$ & Potassium channel protein & yes & no \\
\hline Protein Metabolism & Protein biosynthesis & $\begin{array}{l}\text { Ribosome SSU bac- } \\
\text { terial }\end{array}$ & $\begin{array}{l}\text { SSU ribosomal protein S18p, zinc- } \\
\text { dependent }\end{array}$ & yes & no \\
\hline Protein Metabolism & Protein biosynthesis & tRNAs & tRNA-Ala-CGC & yes & no \\
\hline Protein Metabolism & Protein biosynthesis & tRNAs & tRNA-Ala-GGC & yes & no \\
\hline Protein Metabolism & Protein biosynthesis & tRNAs & tRNA-Arg-ACG & yes & no \\
\hline Protein Metabolism & Protein biosynthesis & tRNAs & tRNA-Arg-CCG & yes & no \\
\hline
\end{tabular}




\begin{tabular}{|c|c|c|c|c|c|}
\hline Category & Subcategory & Subsystem & Role & $\begin{array}{c}\text { Presence in } \\
\text { recovered } \\
\text { P. acnes } \\
\text { genome }\end{array}$ & $\begin{array}{l}\text { Presence } \\
\text { P.acnes } \\
\text { KPA171202 }\end{array}$ \\
\hline Protein Metabolism & Protein biosynthesis & tRNAs & tRNA-Cys-GCA & yes & no \\
\hline Protein Metabolism & Protein biosynthesis & tRNAs & tRNA-Gly-CCC & yes & no \\
\hline Protein Metabolism & Protein biosynthesis & tRNAs & tRNA-Gly-GCC & yes & no \\
\hline Protein Metabolism & Protein biosynthesis & tRNAs & tRNA-Leu-CAA & yes & no \\
\hline Protein Metabolism & Protein biosynthesis & tRNAs & tRNA-Leu-CAG & yes & no \\
\hline Protein Metabolism & Protein biosynthesis & tRNAs & tRNA-Leu-GAG & yes & no \\
\hline Protein Metabolism & Protein biosynthesis & tRNAs & tRNA-Phe-GAA & yes & no \\
\hline Protein Metabolism & Protein biosynthesis & tRNAs & tRNA-Pro-CGG & yes & no \\
\hline Protein Metabolism & Protein biosynthesis & tRNAs & tRNA-Pro-GGG & yes & no \\
\hline Protein Metabolism & Protein biosynthesis & tRNAs & tRNA-Ser-CGA & yes & no \\
\hline Protein Metabolism & Protein biosynthesis & tRNAs & tRNA-Ser-GGA & yes & no \\
\hline Protein Metabolism & Protein biosynthesis & tRNAs & tRNA-Trp-CCA & yes & no \\
\hline Protein Metabolism & Protein biosynthesis & tRNAs & tRNA-Val-CAC & yes & no \\
\hline Protein Metabolism & Protein biosynthesis & tRNAs & tRNA-Val-GAC & yes & no \\
\hline Protein Metabolism & Protein degradation & $\begin{array}{l}\text { Aminopeptidases (EC } \\
\text { 3.4.11.-) }\end{array}$ & $\begin{array}{l}\text { Membrane alanine aminopeptidase } \mathrm{N} \\
\text { (EC 3.4.11.2) }\end{array}$ & yes & no \\
\hline Protein Metabolism & Protein degradation & $\begin{array}{l}\text { Omega peptidases } \\
\text { (EC 3.4.19.-) }\end{array}$ & Isoaspartyl aminopeptidase (EC 3.4.19.5) & yes & no \\
\hline Protein Metabolism & Protein degradation & Protein degradation & $\begin{array}{l}\text { Aminopeptidase YpdF (MP-, MA-, MS-, } \\
\text { AP-, NP- specific) }\end{array}$ & yes & no \\
\hline Protein Metabolism & Protein degradation & Protein degradation & Asp-X dipeptidase & yes & no \\
\hline RNA Metabolism & $\begin{array}{l}\text { RNA processing and } \\
\text { modification }\end{array}$ & $\begin{array}{l}\text { RNA pseudouridine } \\
\text { syntheses }\end{array}$ & $\begin{array}{l}\text { Ribosomal large subunit pseudouridine } \\
\text { synthase } A(E C \text { C.2.1.70) }\end{array}$ & yes & no \\
\hline Respiration & $\begin{array}{l}\text { Electron accepting } \\
\text { reactions }\end{array}$ & $\begin{array}{l}\text { Anaerobic respiratory } \\
\text { reductases }\end{array}$ & $\begin{array}{l}\text { Electron transfer flavoprotein-ubiquino- } \\
\text { ne oxidoreductase (EC 1.5.5.1) }\end{array}$ & yes & no \\
\hline Respiration & $\begin{array}{l}\text { Electron accepting } \\
\text { reactions }\end{array}$ & $\begin{array}{l}\text { Anaerobic respiratory } \\
\text { reductases }\end{array}$ & Ferredoxin reductase & yes & no \\
\hline Respiration & no subcategory & $\begin{array}{l}\text { Biogenesis of c-type } \\
\text { cytochromes }\end{array}$ & $\begin{array}{l}\text { Cytochrome c-type biogenesis protein } \\
\text { DsbD, protein-disulfide reductase (EC } \\
1.8 .1 .8 \text { ) }\end{array}$ & yes & no \\
\hline Respiration & no subcategory & $\begin{array}{l}\text { Quinone oxidoreduct- } \\
\text { ase family }\end{array}$ & Quinone oxidoreductase (EC 1.6.5.5) & yes & no \\
\hline Respiration & no subcategory & $\begin{array}{l}\text { Soluble cytochromes } \\
\text { and functionally rela- } \\
\text { ted electron carriers }\end{array}$ & Ferredoxin & yes & no \\
\hline Stress Response & Heat shock & $\begin{array}{l}\text { Heat shock dnaK gene } \\
\text { cluster extended }\end{array}$ & Signal peptidase-like protein & yes & no \\
\hline Stress Response & Osmotic stress & $\begin{array}{l}\text { Choline and Betaine } \\
\text { Uptake and Betaine } \\
\text { Biosynthesis }\end{array}$ & $\begin{array}{l}\text { L-proline glycine betaine } A B C \text { transport } \\
\text { system permease protein ProW (TC } \\
\text { 3.A.1.12.1) }\end{array}$ & yes & no \\
\hline Stress Response & Oxidative stress & Oxidative stress & Ferroxidase (EC 1.16.3.1) & yes & no \\
\hline Stress Response & Oxidative stress & Oxidative stress & $\begin{array}{l}\text { Iron-binding ferritin-like antioxidant } \\
\text { protein }\end{array}$ & yes & no \\
\hline Stress Response & Oxidative stress & Oxidative stress & Non-specific DNA-binding protein Dps & yes & no \\
\hline Stress Response & no subcategory & $\begin{array}{l}\text { SigmaB stress res- } \\
\text { ponce regulation }\end{array}$ & $\begin{array}{l}\text { Serine phosphatase RsbU, regulator of } \\
\text { sigma subunit }\end{array}$ & yes & no \\
\hline Sulfur Metabolism & no subcategory & $\begin{array}{l}\text { Galactosylceramide } \\
\text { and Sulfatide meta- } \\
\text { bolism }\end{array}$ & Beta-galactosidase (EC 3.2.1.23) & yes & no \\
\hline
\end{tabular}

